\title{
The tissue factor pathway of blood coagulation in health and disease
}

Citation for published version (APA):

Ariens, R. A. S. (1997). The tissue factor pathway of blood coagulation in health and disease. [Doctoral Thesis, Maastricht University]. Universiteit Maastricht. https://doi.org/10.26481/dis.19971217ra

Document status and date:

Published: 01/01/1997

DOI:

10.26481/dis.19971217ra

Document Version:

Publisher's PDF, also known as Version of record

\section{Please check the document version of this publication:}

- A submitted manuscript is the version of the article upon submission and before peer-review. There can be important differences between the submitted version and the official published version of record.

People interested in the research are advised to contact the author for the final version of the publication, or visit the DOI to the publisher's website.

- The final author version and the galley proof are versions of the publication after peer review.

- The final published version features the final layout of the paper including the volume, issue and page numbers.

Link to publication

\footnotetext{
General rights rights.

- You may freely distribute the URL identifying the publication in the public portal. please follow below link for the End User Agreement:

www.umlib.nl/taverne-license

Take down policy

If you believe that this document breaches copyright please contact us at:

repository@maastrichtuniversity.nl

providing details and we will investigate your claim.
}

Copyright and moral rights for the publications made accessible in the public portal are retained by the authors and/or other copyright owners and it is a condition of accessing publications that users recognise and abide by the legal requirements associated with these

- Users may download and print one copy of any publication from the public portal for the purpose of private study or research.

- You may not further distribute the material or use it for any profit-making activity or commercial gain

If the publication is distributed under the terms of Article $25 \mathrm{fa}$ of the Dutch Copyright Act, indicated by the "Taverne" license above, 
The Tissue Factor Pathway of Blood Coagulation in Health and Disease 
CIP-DATA KONINKLIJKE BIBLIOTHEEK, DEN HAAG

Ariêns, Robert Anton Sybrand

The tissue factor pathway of blood coagulation in health and disease/Robert Anton Sybrand Ariëns

Thesis Maastricht - with ref. - with summary in Dutch and Italian ISBN 90-9011198-0

Subject headings: blood coagulation / tissue factor / factor VII tissue factor pathway inhibitor / venous thrombosis /

atherothrombotic disorders

Cover: Harke Kazemier

BIOMEDIA srl

Via C. Farini, 70 - 20159 Milano

Tel. oz/09001310, Fax 02/09001311 


\section{The Tissue Factor Pathway of Blood Coagulation in Health and Disease}

\section{PROEFSCHRIFT}

ter verkrijging van de graad van doctor aan de Universiteit Maastricht, op gezag van de Rector Magnificus Prof. Mr. M.J. Cohen, volgens het besluit van het College van Decanen, in het openbaar te verdedigen op woensdag 17 december 1997 om 16.00 uur

door 


\section{Promotores}

Prof. Dr. H.C. Hemker

Prof. Dr. P.M. Mannucci, University of Milan

Co-promotor

Dr. S. Béguin

Beoordelingscommissie:

Prof. Dr. H.A.M. Neumann (voorzitter)

Prof. Dr. C.E. Blanco

Prof. Dr. M.P. van Dieijen-Visser

Prof. Dr. P.W. de Leeuw

Prof. Dr. P. Prandoni, University of Padua

Prof. Dr. H.J.J. Wellens

This thesis has been prepared in the Angelo Bianchi Bonomi Hemophilia and Thrombasis Centre, Ospedale Maggiore IRCCS, University of Milan, Italy.

Financial support by Rhône Poulenc S.p.A., Milan, Italy, for the publication of this thesis is gratefully acknowledged. 
Aan mijn ouders 



\section{Contents:}

$\mathrm{CH} 1$ General introduction 9

$\mathrm{CH} 2$ The increase with age of the components of the tissue 37 factor coagulation pathway is gender-dependent Ariëns RAS, Coppola R, Potenza I, Mannucci PM. Blood Coag Fibrinol $1995 ; 6: 433-437$

CH 3 Repeated release of the tissue factor pathway inhibitor Ariëns RAS, Faioni EM, Mannucci PM. Thromb Haemost 1994; 72: 327-328

$\mathrm{CH} 4$ Low levels of heparin-releasable tissue factor pathway inhibitor in patients with juvenile thrombosis

Ariens RAS, Alberio $G_{*}$ Moia M, Mannucci PM. Submitted for publication

$\mathrm{CH} 5$ Increased thrombin and plasmin generation together with high plasma levels of activated factor VII in patients with the nephrotic syndrome Ariëns RAS, Coppola $A$, Bottasso B, Moja M, Rivolta $R$, Ponticelli $C_{\text {, }}$ Mannucci PM. Submitted for publication

$\mathrm{CH} 6$ High levels of tissue factor pathway inhibitor in patients with the nephrotic syndrome Ariëns RAS, Moia M, Rivolta R, Ponticelli C, Mannucoi PM. Submitted for publication

$\mathrm{CH} 7$ Tissue factor antigen and activity in human atherosclerotic plaques

Ardissino D, Merlini PA, Ariëns RAS, Coppola R, Bramucci E, Mannucci PM. Lancet 1997; 349: 769-771

$\mathrm{CH} 8$ Ticlopidine pretreatment reduces plasma tissue factor levels during coronary interventions Ariëns RAS, Gregorini L, Bottasso B, Bamonti-Catena $F$, Brambilia $Q$, Fajadet J. Bossi I, Cassagneau B, Marco J. 1st Endovascular Therapy Course: Coronary and Peripheral (21-24 May 1997); Marco J, Henry M, Eds

$\mathrm{CH} 9$ General discussion and conclusions

Samenvatting

Riassunto 



\section{Chapter 1}

\section{General introduction}

1.1 General biochemistry of clotting factors 10

1.2 Tissue factor and factor VII 12

1.3 Biochemistry of the coagulation pathway in the light of 14 major bleeding disorders

1.4 Natural inhibitors of coagulation 18

$\begin{array}{lll}1.4 .1 & \text { Antithrombin } & 19\end{array}$

$\begin{array}{lll}\text { 1.4.2 Protein } \mathrm{C}, \text { protein } \mathrm{S} \text { and thrombomodulin } & 19\end{array}$

1.4.3 Tissue factor pathway inhibitor 21

1.4.4 Heparin cofactor II 24

1.4.5 a.2-Macroglobulin 24

$1.5 \quad$ Natural anticoagulants and thrombotic disorders 26

1.6 Aim of the studies 28

$\begin{array}{lr}\text { References } & 29\end{array}$ 
Coagulation or blood clotting is a vital mechanism, safeguarding the organism from bleeding, and guaranteeing the integrity of the vascular system for normal circulation of the blood. Vascular damage very rapidly activates clotting, which involves a series of specific zymogen to enzyme conversions by limited proteolysis (clotting factor activation) leading to thrombin formation and subsequent platelet aggregation and fibrin deposition. One of the characteristics of coagulation is amplification, so that even a small trigger results in sufficient and explosive platelet aggregation and fibrin deposition. Understandably, coagulation has to be very finely balanced, since deficiency leads to bleeding, and excess leads to thrombosis or intravascular clotting. Therefore, the procoagulant enzymes are counteracted by anticoagulant proteins in a complex system of biochemical reactions including both positive and negative feedback mechanisms.

\subsection{General biochemistry of clotting factors}

Most of the clotting factors" (FII, FX, FIX, FXI, FXII, FVII) are pro-enzymes, which are all members of the chymotrypsin superfamily. This superfamily is placed in the enzyme class of serine proteinases, which also includes regulatory proteinases of complement activation, fibrinolytic cascade, and many of the simple digestive enzymes like trypsin, chymotrypsin, and other pancreatic proteinases. In addition to the trypsin-homologous catalytic region with the active site serine residue, the more complex regulatory serine proteinases like clotting factors contain large non-catalytic regions, which determine their biological specificity. Due to these large non-catalytic regions, regulatory serine proteinases have an increased substrate specificity and proteolyze only one or a few substrates, whereas the simple digestive serine proteinases universally hydrolyze many different ingested proteins. Four types of domains can be recognized in the non-catalytic region of a regulatory serine proteinase: kringle domains, finger domains, growth factor domains, and vitamin K-dependent calcium-binding domains. Evolutionary trees of serine proteinases, based on the assembly of the non-catalytic regions from domain modules by exon shuffling, have been proposed. ${ }^{1.2}$

Activation of the clotting factors consists in a proteolytic cleavage of the zymogen, accompanied by the release of an activation peptide. The resultant active serine proteinase has a much shorter plasma half-life than its zymogen. ${ }^{3}$ The coagulation factors VII, IX, X and II (prothrombin) contain vitamin K-de-

"Clotting factors are designated " $F$ ", which stands for factor, followed by a Roman numeral, and " $a$ " if activated (cf. "FVllat" means activated factor seven). 
pendent calcium-binding domains. Vitamin K-dependent post-translational carboxylation of glutamic acid residues in this domain results in $\gamma$-carboxyglutamic acid (Gla) with high affinity for calcium (fig. 1). ${ }^{4}$

Glu

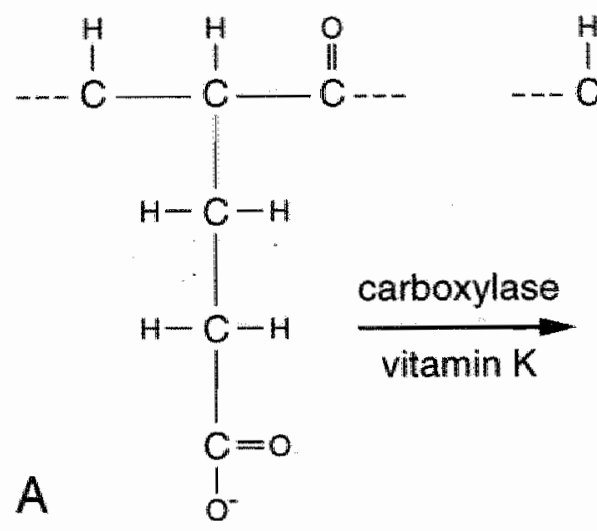

Gla

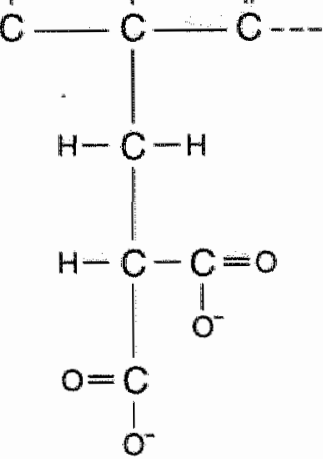

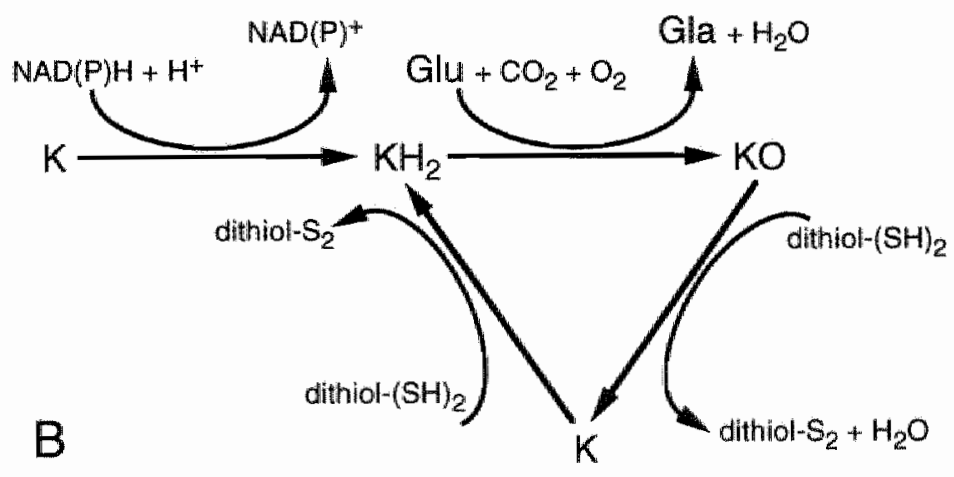

Figure 1. Panel A Vitamin k-dependent carboxylation of the amino acid glutamate (Glu) into $\gamma$ carboxyglutamate (Gla).

Panel $B$ Vitamin $K(K)$ is comerted into a hydroquinone $(K H 2)$ by a dithio or a $M A D(P) H-d e p e n d-$ ent reduction reaction, which is then oxiclized into an epoxide (KO) during the carboxylation of glutamatic acid residues (Glu $\rightarrow$ Gla). The epoxide is reconverted into vitamin by by dithioldependent reduction.

Calcium ions form a bridge between negatively charged phospholipid membranes and these negatively charged Gla-residues. Due to the membrane binding of vitamin $\mathrm{K}$-dependent clotting factors the $\mathrm{K}_{\mathrm{m}}$ of some key coagulation reactions is reduced by several orders of magnitude, resulting in marked acceleration of the reaction velocity at physiological substrate concentrations. 
Therefore, deficiency of vitamin $K$, resulting in synthesis of clotting factors that do not bind to negatively charged membranes, leads to bleeding, of which the severity is relative to the deficiency state. Furthermore, coumarin and wartarin, which are oral drugs that efficiently block the carboxylation of glutamic acid residues, are potent inhibitors of the coagulation, and are widely used for anticoagulant prevention and therapy in thrombotic disease..$^{5}$

Two general types of assay are used to quantify clotting factor zymogens in plasma: 1) antigen assay, usually enzyme-inked immunosorbent assay (ELISA), immunodiffusion or radio-immuno assay (AIA) and 2) functional assay, assessing the enzymatic activity either on a physiological substrate (clotting assay) or on an artificial color-releasing oligopeptide (chromogenic assay). Clotting assays are based on measuring the clotting time of the test sample diluted in plasma which is deficient or depleted of the clotting factor that is being examined. Chromogenic assays are based on the use of small specific substrates, which release paranitroanaline when hydrolyzed by the coagulation factor. in addition to the methods which quantify total zymogen concentrations in plasma, very sensitive methods have recently been developed to measure specifically the extent of activation of the coagulation system. These assays are usually ELISA with a capture-antibody that is specific for the activation peptide of one of the coagulation factors, It has been shown that in physiological conditions trace amounts of activated clotting factors circulate in plasma, and that in thrombotic disease the concentration of these enzymes may increase. ${ }^{6-10}$

\subsection{Tissue factor and factor VII}

Coagulation is triggered when blood comes into contact with tissue factor (TF), a transmembrane glycoprotein of $53 \mathrm{kD}$. TF needs to be inserted into a phospholipid bilayer (cell-)membrane to function properly as a trigger of blood clotting. Without phospholipids, for example after detergent solubilization with Triton $X-100$, TF is not functional. "TF is normally only expressed by perivascular cells, and vital organs like the brain, lungs and placenta are very rich in this protein. ${ }^{2}$ It is obvious that the abundance of TF in these organs serves to prevent life-threatening bleeding. TF is distributed as a hemostatic "envelope" ready to activate coagulation when vascular integrity is disrupted. It surrounds blood vessels in the adventitia and is present in the epidermis, mucosal epithelium, subjacent stromal cells in the skin and internal mucosae, and in the fibrous capsules that encase the organs, providing a continuous hemostatic barrier with the external environment. ${ }^{13}$ TF has been detected adjacent to cholesterol clefts and within the necrotic cores of atherosclerotic plaques, and is probably responsible for the thrombotic response to plaque ruplure (this 
thesis, chapter 7$)^{14-15}$ In addition to the presence of TF in atherosclerotic plaques and perivascular cells, some intravascular cells, such as monocytes, have been shown to be able to express TF both in vitro and in vivo. ${ }^{16: 20}$ Therefore, various inflammatory and neoplastic disease states may induce a procoagulant stimulus due to TF within the intact blood vessel.

The actual trigger of blood coagulation is not TF, but the complex between TF and the vitamin K-dependent serine proteinase FVII. FVII is a single chain glycoprotein of $48 \mathrm{kDa}$, which circulates in blood with a concentration of 10 $n M{ }^{21}$ FVII has very high affinity for TF, so when blood comes in contact with TF, the exposed TF will rapidly be saturated with FVII. Recent crystallographic analysis of the TF - FVII complex has shown that the area of interaction between the two proteins is very flat, there are no clefts and protrusions in the interaction plane. ${ }^{22}$ This makes biochemical interference with the complex formation rather difficult, and restricts the possibilities of development of anticoagulant drugs interfering with TF - FVII complex formation. FVII is activated by a single scission of the zymogen into two chains connected by a disulfide bridge. Unlike during activation of the other serine proteinases, no activation peptide is released when zymogen $\mathrm{FVII}$ is activated. In vitro FVIII can be activated by $\mathrm{FXa}^{23}{ }^{23} \mathrm{FIXa},{ }^{24}$ thrombin, ${ }^{23}$ and FXIIa. ${ }^{24-26}$

Availability of new, activation peptide-specific, ELISA for various clotting factors has greatly improved the knowledge of the extent of activation of these factors in physiological and pathological conditions. Unfortunately, this kind of assay could not be developed for FVII, since activation of FVII does not lead to the release of an activation peptide. Recently, however, a specific assay for the activated form of FVII has been developed, based on the characteristics of a recombinant truncated form of TF. This TF $1-218$ lacks the membrane anchoring region of TF, and therefore it does not bind phospholipids and is water soluble. TF $1-218$ functions normally as a catalyst of the activation of $F X$ and $F \mid X$ by FVIla; it does not, however, catalyze the activation of FVII. ${ }^{27}$ Hence, a simple clotting assay, similar to the traditional clotting assay for FVII zymogen, using TF1-218 instead of full-length wild-type TF, is specific for the activated form of FVII. ${ }^{26}$

In the presence of calcium, the TF - FVII complex activates FX ${ }^{3.29}$ and $F I X{ }^{30.31}$ Some debate still exists on how exactly the clotting cascade is triggered by the TF - FVII complex. The TF - FVII complex is fully functional only when FVII is in the activated form. Some previous studies have shown that FVII, unlike other clotting enzymes, is a peculiar serine proteinase in the sense that also the zymogen has some proteolytic activity when bound to tissue factor ${ }^{32,33}$ This might explain how coagulation is triggered by a positive feedback mechanism when blood comes into contact with TF. TF binds FVII and some FX will be activated by the FVII zymogen. These traces of FXa then activate the FVII 
bound to TF, leading to a fully active procoagulant stimulus. Due to the recent availability of a specific clotting assay for the activated form of FVII, other studies have shown that trace amounts of FVIla are normally present in the blood. ${ }^{28.34}$ According to these studies, traces of circulating FVIlla could be responsible for triggering coagulation when blood is exposed to TF.

Fundamentally, there is no difference whether activation is caused by proteolysis of FX by the FVII zymogen, or circulating traces of FVIla. Whatever the exact mechanism of activation is, clotting is triggered when FVII encounters $T F$, and minute amounts of activated clotting factors rapidly lead to a fully active trigger, due to positive feedback activation of FVII by FXa, FIXa and thrombin.

\subsection{Biochemistry of the coagulation pathway in the light of major bleeding disorders}

It has long been thought that there would be two independent pathways of coagulation, called intrinsic and extrinsic pathway, each activated by a different trigger (fig. 2). The intrinsic pathway was shown to be triggered by the contact of blood with negatively charged artificial surfaces like glass, which leads to the activation of $\mathrm{FXII}$, and the extrinsic pathway was known to be triggered when blood contacts TF. With this division of the coagulation in two pathways, some major bleeding disorders (deficiencies of FVII, F|X, FVIII, FX, FXI) could easily be explained, but it also led to some unsolvable riddles. Why is hemophilia (a defect of the intrinsic pathway) such a severe bleeding disease when the extrinsic pathway is apparently unimpaired? Why does deficiency of FXI lead to bleeding, whereas deficiency of FXII does not and may lead to thrombosis? More and more evidence, gathered in the last 10 years, has shown that there is only one major pathway of blood clotting (fig. 3), in which the formerly considered independent pathways interact. This new vision of the coagulation as one single cascade has resolved most of the former enigmas.

As mentioned before, clotting is triggered when FVII, circulating in blood, contacts TF, exposed after vascular damage. The role of FVII in coagulation is essential, since severe deficiency leads to a major bleeding disorder. ${ }^{35,36}$ The TF - FVII(a) complex proteolytically activates FX (fig. 3). This is one of the calcium-dependent clotting reactions, sensitive to vitamin $\mathrm{K}$ deficiency. $\mathrm{FX}$ is a vitamin $\mathrm{K}$-dependent serine proteinase of $55 \mathrm{kDa}$ and has a plasma concentration of $160 \mathrm{nM}$. During activation of FX an activation peptide of 51 amino acids is released, and this peptide can be measured in plasma. ${ }^{7}$ Deficiency of $\mathrm{FX}$ is a rare bleeding disorder which can lead to severe bleeding. ${ }^{37,36}$

Besides directly activating FX, the TF - FVII(a) complex also activates FIX, which in its turn together with the cofactor FVIlla will activate FX (fig. 3). ${ }^{30.31}$ This mechanism could finally explain why hemophilia, the major severe bleed- 


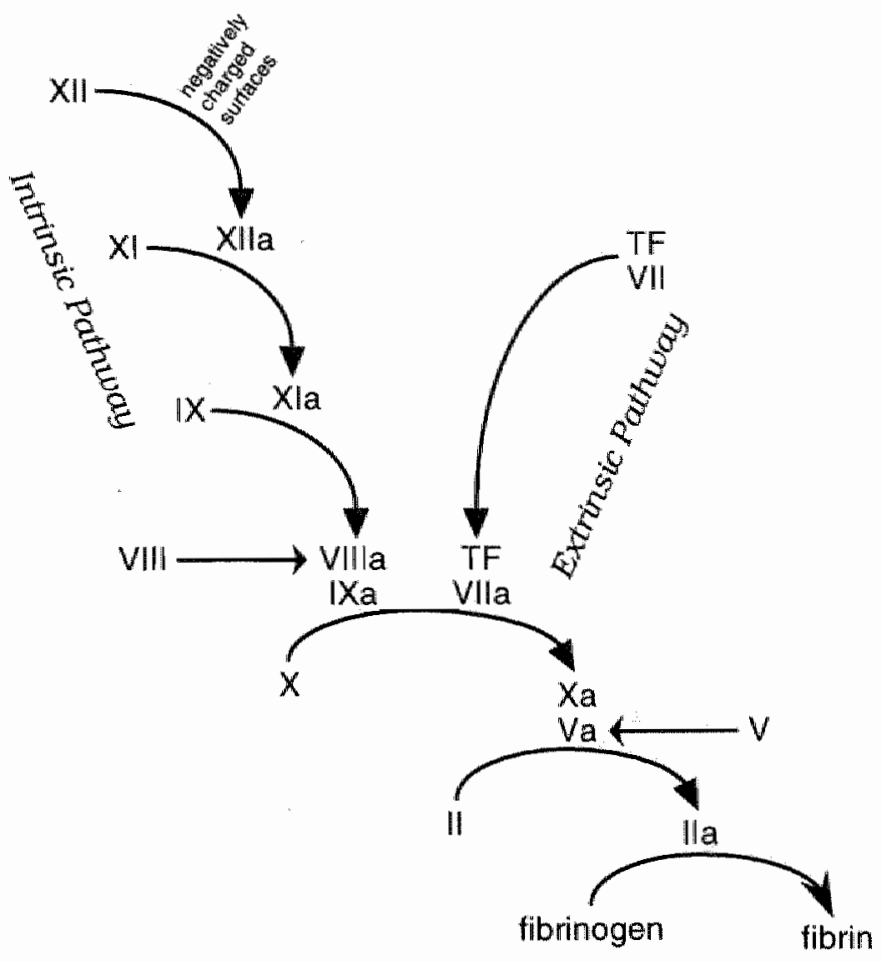

Figure 2. The classical vision of the coagulation cascade with its division in two pathways: the intrinsic and extrinsic pathway.

ing disease (with an incidence of around 1 per 20.000) due to deficiency of FVIII or FIX, leads to such severe bleeding despite the normal presence of TF. Direct - activation of FX by TF - FVII(a) is not sufficient, and additional activation of FX via $\mathrm{FIX}$ is indispensable for complete hemostasis. Christmas factor or FIX is a vitamin $\mathrm{K}$-dependent serine proteinase with a molecular weight of $57 \mathrm{kDa}$ and circulates in plasma with a concentration of $80 \mathrm{nM}$. The FIX activation peptide of $11.1 \mathrm{kDa}$ can be measured using ELISA.

Like the activation of FX by the TF . FVII(a) complex, the activation of FX by FIXa is a calcium-dependent coagulation reaction that takes place on a phospholipid bilayer. FVIII, a glycoprotein of around $280 \mathrm{kDa}$ with a plasma concentration of $1 \mathrm{nM}_{2}^{39}$ serves as a cofactor for this reaction (fig. 3). Cleavage of FVIII by thrombin is required for its activity. In blood, FVIII circulates bound to von Willebrand factor (vWF), a very large multimeric glycoprotein with a plasma concentration of $23-45 \mathrm{nM}(5-10 \mu \mathrm{g} / \mathrm{ml})$. Gel electrophoresis of $\mathrm{WWF}$ shows that this protein exists as a series of multimers with molecular weights 


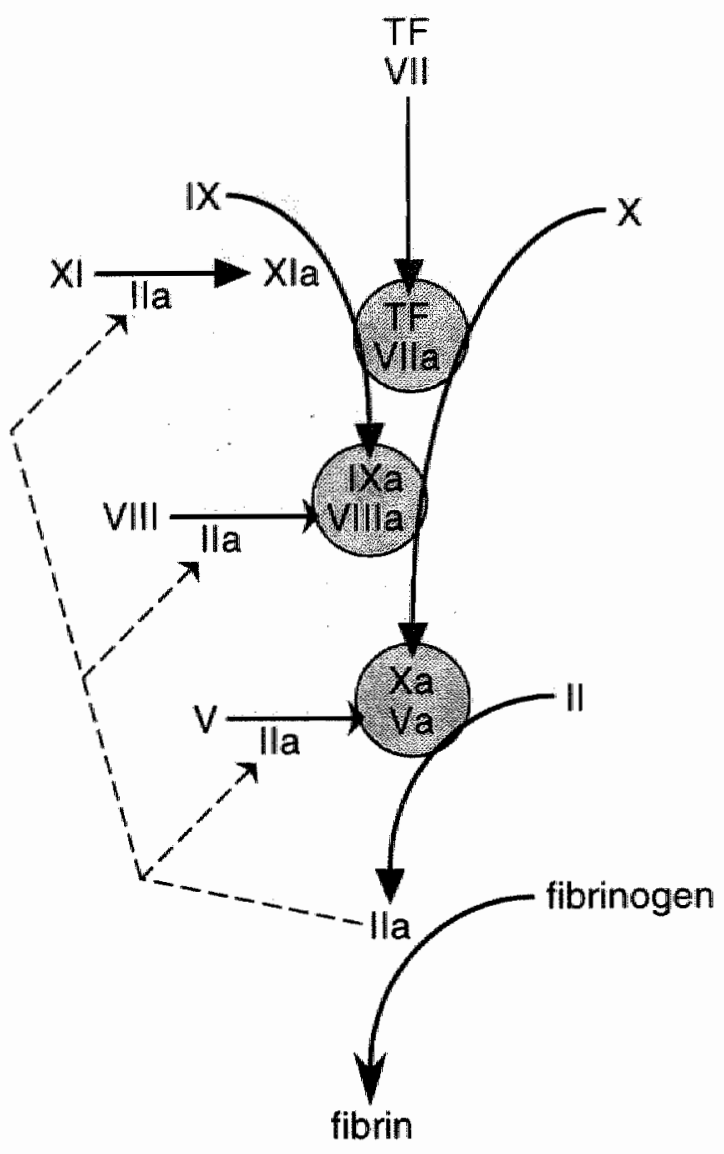

Figure 3. Codgulation, represented as one major pathway triggered by TF / FVII, is a hypothesis that tits experimental and clinical data better.

extending to $20000 \mathrm{kDa}$. Complete reduction with $\beta$-mercaptoethanal or dithiothreitol results in one subunit species of $200-240 \mathrm{kDa} .{ }^{39} \mathrm{VWF}$ is involved in platelet adhesion, and is a stabilizer of FVIII activity in plasma. Deficiency of WWF leads to a rather common (incidence around 1 per 40.000) disease: von Willebrand disease, ${ }^{40}$ characterized by a combined platelet and plasma type hemorrhagic diathesis.

The FXa generated by FIXa and FVIla is involved in a third important calciumdependent clotting reaction: the activation of Fll or prothrombin (fig. 3). Prothrombin, a vitamin K-dependent glycoprotein of $72 \mathrm{kDa}$ with a plasma concentration of $1.5 \mu \mathrm{M}$, is cleaved by FXa at two sites, at peptide bond Arg 274 - Thr 275 and Arg 323 - Ile 324 , resulting in the serine proteinase thrombin and the activation peptide fragment $1+2(F 1+2){ }^{41,42} \mathrm{~F} 1+2$ is readily measurable in a blood sample, and recent 
studies have proposed that increased $\mathrm{F} 1+2$ levels are a marker of prethrombotic state, i.e. a state of a hyperactive coagulation system preceding thrombosis. ${ }^{6.10}$ Analogous to the tenase complex, the prothrombinase complex is composed of prothrombin, $\mathrm{FXa}$, and a reaction colactor, $\mathrm{FV},{ }^{43}$ a glycoprotein of $350 \mathrm{kDa}$ with a plasma concentration of $30 \mathrm{nM}$. Similar to FVIII, the cofactor function of $F V$ is dependent on activation of this factor by thrombin. Deficiency of prothrombin is probably one of the most uncommon hereditary bleeding disorders, with relatively severe bleeding symptoms. ${ }^{40}$

The final step in the coagulation pathway is the conversion of fibrinogen into fibrin by thrombin (fig. 3). Fibrinogen is a fibrous glycoprotein of $330 \mathrm{kDa}$ with a plasma concentration of $9.09 \mu \mathrm{M}$. Upon proteolysis of fibrinogen by thrombin, small polar peptides (fibrinopeptides: FPA and FPB) are released, and the resulting fibrin monomers spontaneously polymerize into multimer strands, due to electrostatic interaction. ${ }^{44}$ The fibrin multimer strands are subsequently covalently cross-linked and stabilized by FXIII, which is activated by thrombin. FXIIla is not a serine proteinase but a sulfhydryl-type transgiutaminase of 320 $\mathrm{kDa}$ with a plasma concentration of $66 \mathrm{nM}{ }^{45}$ The hereditary deficiencies of both fibrinogen and FXIII are very rare, and the bleeding symptoms are moderate to severe. ${ }^{40,46}$ Whereas in homozygous deficiency FXIII is practically absent from the plasma, absolute deficiency of fibrinogen does not exist, probably it is incompatible with life. Because of the rarity of fibrinogen deficiency it has not been possible to establish accurately the plasma concentration of this clotting factor necessary for normal hemostasis, but it is generally accepted that a minimum of one third of the normal concentration $(3.03 \mu \mathrm{M})$ is required. ${ }^{46}$ The fibrinopeptide A (FPA), released during proteolysis of fibrinogen by thrombin, is measurable with ELISA. Like F1+2, increased plasma levels of FPA have been shown to be associated with thrombotic tendency. ${ }^{10}$

Thrombin plays a central role in hemostasis: it not only converts fibrinogen into fibrin and activates platelets, but it also activates FV, FVIII, FVII, FXIII, and $\mathrm{FXI},{ }^{47.48}$ and it activates an anticoagulant system as will be discussed later ( $\$$ 1.4.2). The activation of $F V$ and $F V I I I$ by thrombin are important positive feedback loop mechanisms, resulting in an amplified thrombin production, and therefore assuring a sufficient response of the coagulation system to the stimulus. Also the activation of FXI (a serine proteinase of $160 \mathrm{kDa}$ with a plasma concentration of $30 \mathrm{nM}$, which activates $F(X)$ by thrombin serves as a reinforcement of thrombin production (fig. 3). Moderate deficiency of $\mathrm{FXI}$, which is very common in Ashkenazi Jews (incidence around 1 per 1000), is a bleeding disease with mild symptoms. ${ }^{40}$ Severe deficiency with plasma levels below $3 \%$, which is very rare, produces a severe hemophilia syndrome. FXIl is not included in the FXI positive feedback loop, ${ }^{47,48}$ and therefore FXII deficient patients do 
not show a tendency to bleed. Instead, these patients have episodes of venous or arterial thrombosis, ${ }^{49-51}$ like in the case of the first described FXII deficient patient Hageman, who died of myocardiall infarction. ${ }^{52}$ In the presence of high molecular weight kininogen, FXII or Hageman factor, a glycoprotein of $80 \mathrm{kDa}$ with a plasma concentration of $375 \mathrm{nM}$, is activated by and reciprocally activates the serine proteinase kallikrein. ${ }^{53}$ Besides activating FXI, FXIla $/$ kallikrein are also involved in the activation of the complement system and the generation of kinins (Fig. 4). In addition, kallikrein has been shown to convert pro-urokinase into urokinase (U-PA) ${ }^{53}$ leading to the activation of fibrinolysis (Fig. 4), the natural defense system against excess fibrin deposition. Therefore, deficiency of FXII might lead to hypofibrinolysis and consequent thrombosis. The involvement of FXII and kallikrein in the coagulation, complement, kinin, and fibrinolysis systems is a good illustration of how different biological systems can be interlinked.

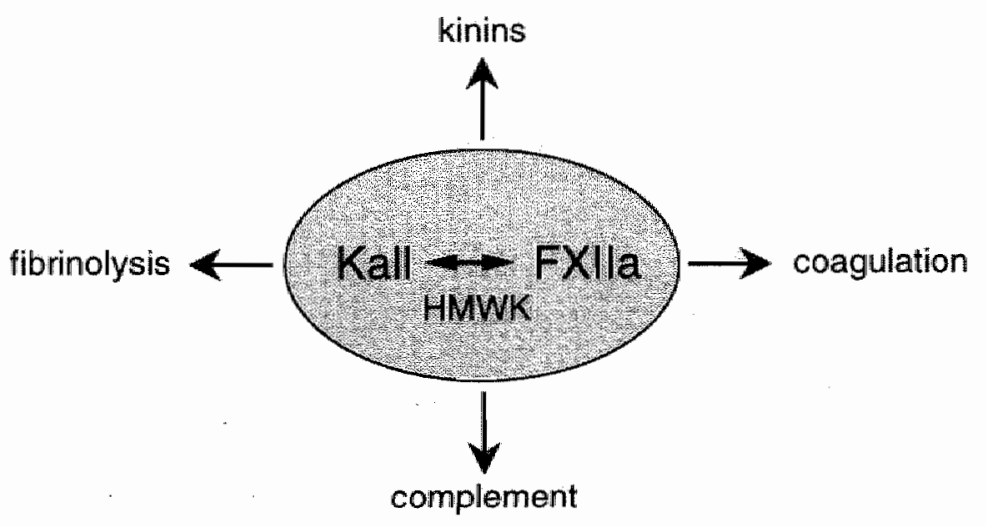

Figure 4. Reciprocal activation of the serine proteinases FXlla and kallikrein (Kall) in the presenw ce of high molecular-weight kininogen (HMWK). FXlla and kallikrein form a link between the coagulation, complement, kinim and fibrinolysis sytems.

\subsection{Natural inhibitors of coagulation}

Toprotect the organism from excessive coagulation, which could result in thrombosis, several naturally occurring inhibitors limit the activity of the procoagulant cascade. For two reasons natural anticoagulation plays an important roie. First, since minute amounts of activated clotting factors (FV/la, FXa, thrombin) are present in nomal, physiological conditions, inhibition is necessary to prevent inopportune triggering of the coagulation. Second, once triggered, coagulation is such a fast, snowballing sequence of reactions, that it has to be controlled in space and time. In other words, the clotting process has to be limited to the site of vascular damage, to prevent 
occlusive intra-vascular clot formation. Furthermore, when the vascular integrity has been restored, the process must come to an end.

The natural anticoagulants have different mechanisms of action. Some inhibitors like antithrombin, heparin cofactor II and tissue factor pathway inhibitor are essentially substrates, which interact readily with the procoagulant enzyme, but do not dissociate after binding to the active site. Activated protein $\mathrm{C}$ is an enzyme itself, and inactivates the cofactors of coagulation by proteolysis. A third mechanism of the relatively high molecular weight inhibitor $\alpha 2$-macroglobulin involves the capture of the coagulation factor within a cleft of the inhibitor, and the resultant complex is cleared from circulation.

\subsubsection{Antithrombin}

Antithrombin (AT) is the natural inhibitor of thrombin. ${ }^{54-56}$ Besides thrombin it also inhibits FXa, FIXa, FXla, FXIla, ${ }^{56,57}$ but in vivo mainly the inhibition of thrombin and FXa are of physiological significance (fig. 5). AT is a glycoprotein of $55 \mathrm{kDa}$ with a plasma concentration of $2.25 \mu \mathrm{M}$ and is a member of the protein superfamily of serpins (serine proteinase inhibitors). ${ }^{58}$ Members of this superfamily are found in mammals, insects, ${ }^{59}$ plants, ${ }^{60}$ and viruses. ${ }^{61}$ Serpins "feign" to be a good substrate of the target enzyme, and bind irreversibly to the active site of the enzyme. They contain a reactive site loop, similar to the site of proteolysis of the serine proteinase substrates, which binds to the serine residue of the enzyme. Subsequent hydrolysis of the reactive site loop of the serpin does not take place or is very slow , and the inhibitor remains bound to the enzyme. The resultant serpin - proteinase complex is cleared from circulation by receptor mediated cellular internalization ${ }^{62.63}$ In addition to the substrate like active site loop, AT contains a positively charged domain with high affinity for negatively charged glycosaminoglycans like heparin, a widely used anticoagulant drug. Heparin acts as a catalyst or cofactor for the inhibition of thrombin or FXa by AT. ${ }^{55.56,64}$

\subsubsection{Protein $\mathrm{C}$, protein $\mathrm{S}$ and thrombomodulin}

The protein $C(P C)$ anticoagulant system reduces thrombin formation by inactivating proteolytically the tenase and prothrombinase cofactors. FVIIla and FVa (fig. 6). PC is a vitamin K-dependent serine proteinase of $62 \mathrm{kDa}$ with a plasma concentration of $50 \mathrm{nM}$, that after activation by (thrombomodulinbound) thrombin cleaves three peptide bonds in FVa (amino acids 306, 506 and 679) and two peptide bonds in FVIIlla (amino acids 336 and 562). ${ }^{65}$ This reaction is calcium- and phospholipid-dependent, and protein $S$ (PS), a vitamin 


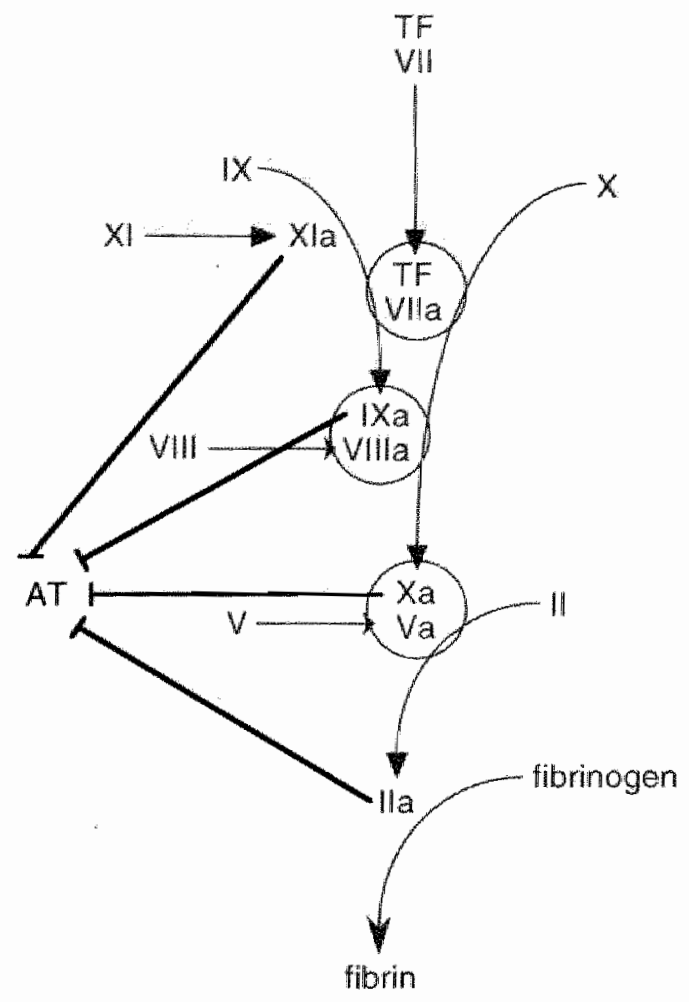

Figure 5. Inhibition of the coagulation by antithrombin (AT). AT inhibits Flla (thrombin), FXa, FlXa, and FXla by binding irreversably to the active site of these enzymes.

K-dependent glycoprotein of $69 \mathrm{kDa}$ with a plasma concentration of $145 \mathrm{nM}$, serves as a cofactor or catalyst of the inhibition (fig. 7), ${ }^{66}$ comparable to the function of FVIIla and FVa in the tenase and prothrombinase reactions respectively. Around $40 \%$ of the total PS in blood circulates freely, while the remaining $60 \%$ is bound to the $\mathrm{C} 4 \mathrm{~b}$ binding protein (C4BP), a high molecular weight protein $(570 \mathrm{kDa})$ with a plasma concentration of $0.26 \mu \mathrm{M}$ which is involved in the complement system. ${ }^{66}$ Oniy the free PS partakes in the inactivation of $\mathrm{FVa}$ and FVIIla. Therefore, like FXII, the PC anticoagulant system is a link between the coagulation and complement cascades.

Thrombin activates the zymogen $\mathrm{PC}$ by hydrolysis of residue Arg 14, resulting in the active serine proteinase (APC) and an activation peptide of 14 amino acids. ${ }^{65}$ Free thrombin, however, has only negligible affinity for the $\mathrm{PC}$ zymogen. Trombomodulin, a transmembrane glycoprotein of $75 \mathrm{kDa}$, which is expressed by endothelial cells, binds thrombir and induces a (small but significant) conformational change in the enzyme which alters it specificity: upon binding to thrombomodulin, the affinity of thrombin for the substrate fibrinogen is lost, and its affinity for PC is increased (fig. 7). ${ }^{67}$ Hence, the PC anticoagulant system forms a negative feedback loop in the production of thrombin, 


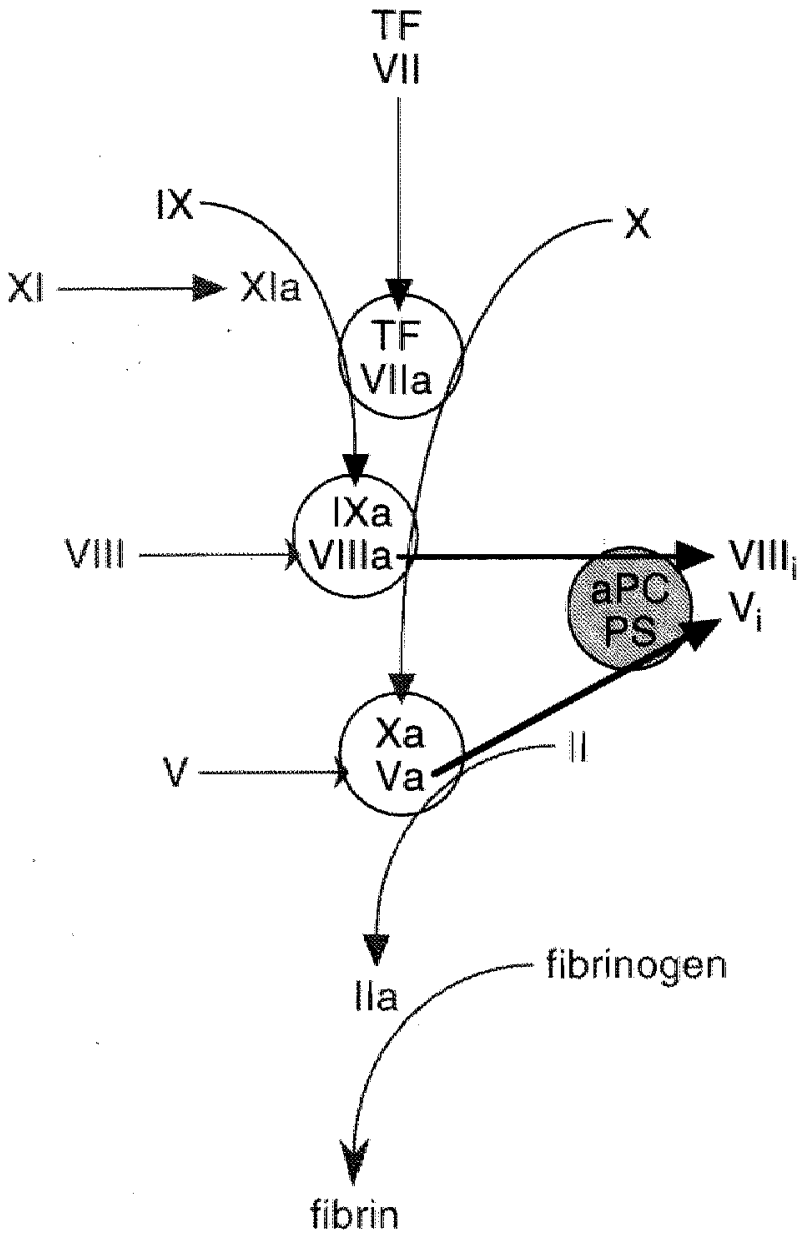

Figure 6. Inhibition of the coagulation by activated protein $\mathrm{C}(\mathrm{aPC}$ ) and proteim $S$ (PS). In the presence of PS, aPC proteolyses the coagulation cofactors FVilla and FVa, resulting in inactivation of these corac tors (FVilii and FWi).

and is regulated by thrombin itself and by the expression of thrombomodulin.

\subsubsection{Tissue factor pathway inhibitor}

The tissue factor pathway inhibitor (TFPl), previously known as lipoprotein associated coagulation inhibitor ( $L A C l)$ or extrinsic pathway inhibitor (EPI), is the natural inhibitor of the TF - FVIla complex..$^{68.70}$ TFPI first binds and inhibits FXa in a calcium-independent reaction. The TFPI - FXa complex then binds and inhibits the TF - FVIla complex in a calcium-dependent manner, assembling a quaternary inhibitory complex. ${ }^{71,72}$ Since some $\mathrm{FX}$ has to be activated by the TF - FVIla complex before TFPI can inhibit this complex, the TFPI anticoagulant system forms a negative feedback loop (fig. 8). 


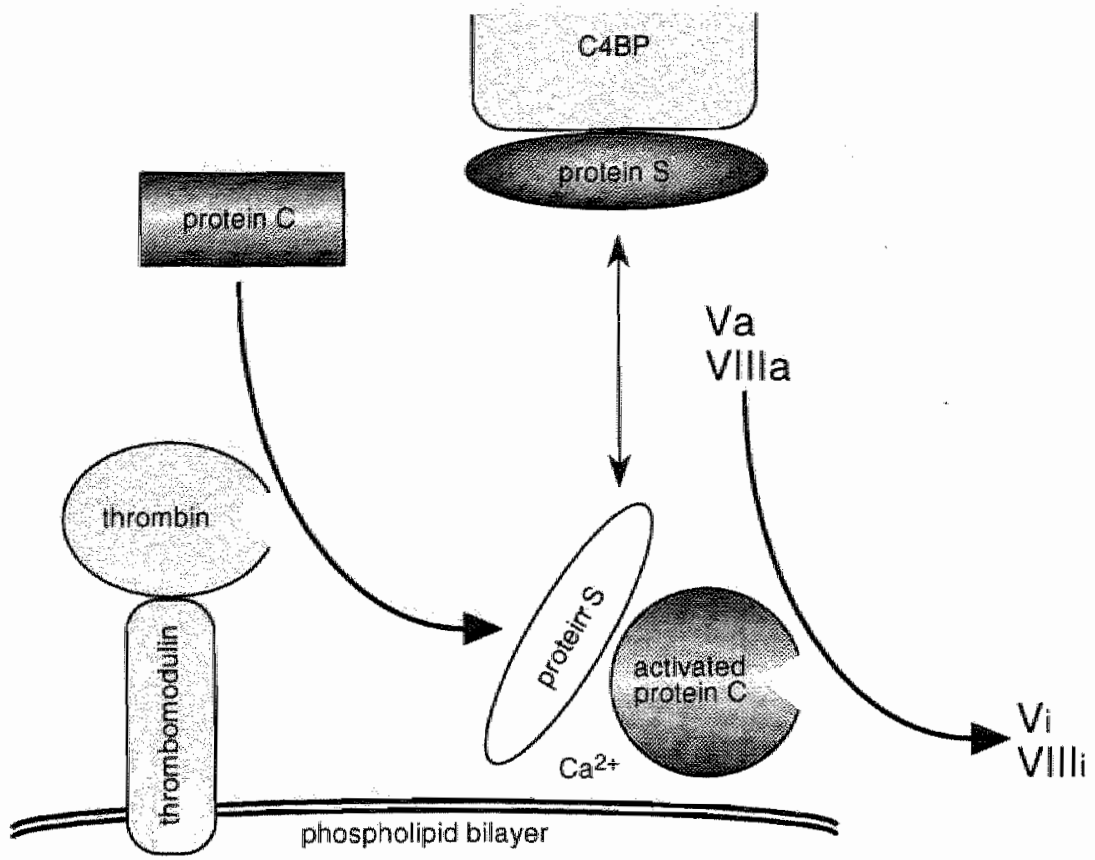

Figure 7. The protein $C$ anticoagulant system. Upon binding to Thrombomodulin, thrombin acti-

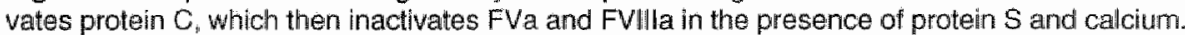
Around $50 \%$ of protein $S$ is bound to $C 4 b$ binding protein (C4BP) and hactive, the remaining $40 \%$ is firee.

TFPl is a glycoprotein of around $40 \mathrm{kDa}$ with a plasma concentration of $2.5 \mathrm{nM}_{3}^{73}$ and is a member of the protein superfamily of kunins, which is encountered throughout the animal kingdom. This protein superfamily, named after its discoverer, includes inhibitors like aprotinin Kunins contain one or more kunitz-domains, which bind to the active site of the target proteinase in a reversible but very tight-binding manner. The TFPI molecule contains three kunitz-domains. Site-directed mutagenesis of the $P_{1}$ residues in the kunitz-domains of recombinant TFPI demonstrated that the amino-terminal domain binds to the active site of FVlia, and the middle domain binds to the active site of $\mathrm{FXa}^{74}$ The function of the carboxy-terminal kunitz-domain remains unknown: it could be involved in the binding of TFPI to plasma lipoproteins. In addition to the three kunitz-domains, TFPI contains a positively charged domain close to the carboxy-terminus with high affinity for negatively charged glycosaminoglycans, similar to the heparin-binding domain of AT. ${ }^{75.76}$

The majority of TFPI found in plasma is bound to lipoproteins, only a small fraction circulates free. Of the TFPI bound to lipoproteins, most is associated with low-density lipoproteins (LDL), some with high-density lipoproteins (HDL), and traces are found in the very low-density lipoproteins (VLDL). ${ }^{70,77}$ Two major molecular forms of TFPI exist in plasma: one of $34 \mathrm{kDa}$, which is a proteolytically truncated form that lacks the carboxy-terminal portion of the molecule including 


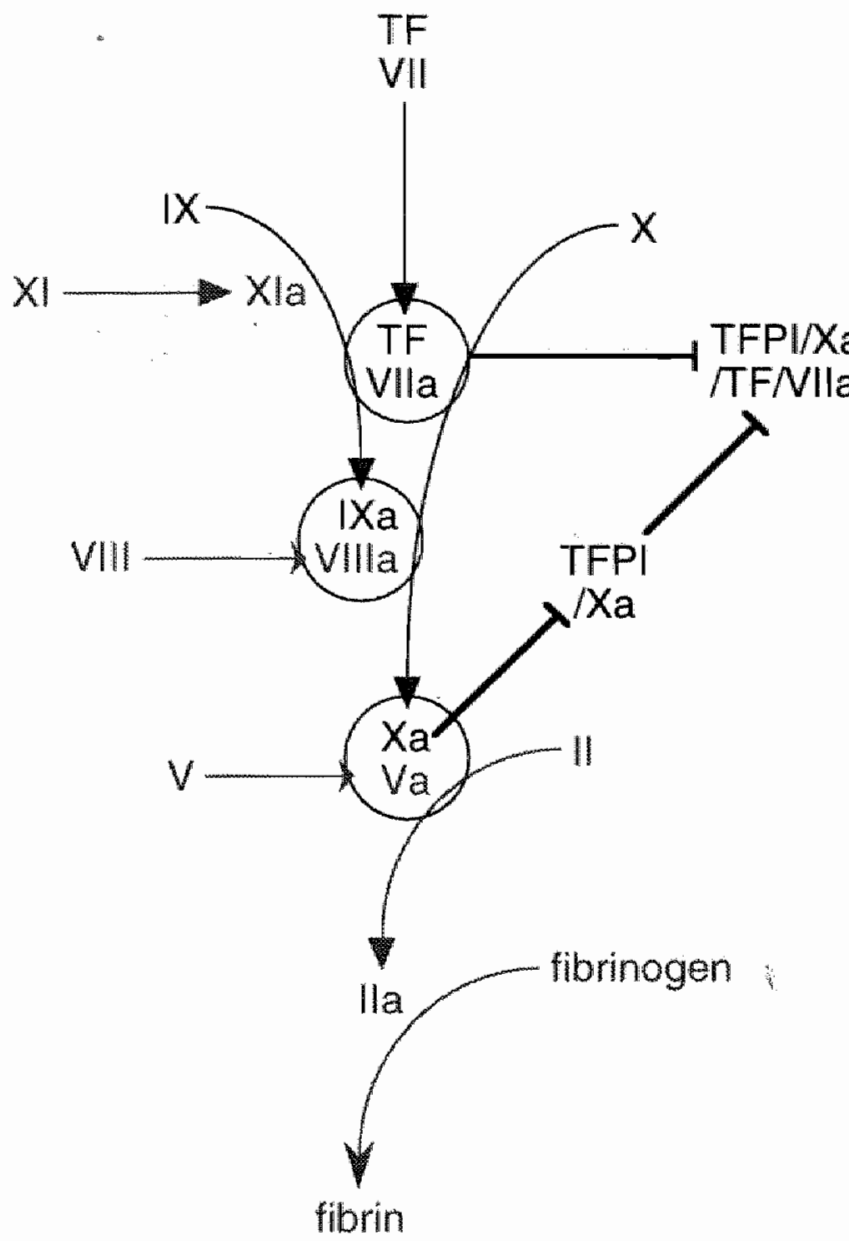

Figure 8. Inhibition of the coagulation by tissue factor pathway inhibitor (TFPI). TFPl first binds and inhibits FXa lin a calcium-independent reaction. The TFPI / FXa complex then binds and inhibits TF / FVlla in a calciumdependent reaction, leading to the formation of a quaternary complex.

at least part of the third kunitz-domain, and one of $41 \mathrm{kDa} .^{77.76}$ Western blotting studies have shown that the $41 \mathrm{kDa}$ form of TFPI, which is mainly found in the HDL-fraction, contains both TFPI and apolipoprotein A-II, and reduction with $\beta$-mercaptoethanol separates the two molecules. Apparently, this form is composed of the truncated $34 \mathrm{kDa}$ form of TFPI bound to apolipoprotein A-II ( $7 \mathrm{kDa}$ ) via a disulphide bridge ${ }^{77.79} \mathrm{In}$ addition to these two predominant forms, there are various less abundant forms of higher molecular mass, which are represented by full-length TFPI ( $43 \mathrm{kDa}$ ) and by TFPI truncated at the carboxyterminus to a variable extent. ${ }^{78}$ It has been suggested that leukocyte elastase is the enzyme that is responsible for the progressive degradation of the carboxy-terminus of TFPI in plasma. ${ }^{80,81}$

In addition to the TFPI circulating in blood, a substantial part of this inhibitor is bound 
to the vessel wall and released by heparin. Injection of heparin increases the plasma levels of TFPI two to four fold (this thesis, chapters 3 \& 4) ${ }^{82.83}$ Hepanin binds the TFPI molecule at the positively charged domain near the carboxy-terminus. Most likely, heparin-releasable TFPI is bound to glycosaminoglycans present on the luminal surface of the vascular endothelium, and the injection of heparin or other glycosaminoglycans temporarily mobilizes this major fraction (this thesis, chapter 3).

A third fraction of TFPI is found in platelets. This part of the inhibitor is synthesized by megakaryocytes, and is contained by granules of the platelet. These granules are different from the a-granules that contain WWF. Stimulation of the platelets with thrombin induces exocytosis of the contents of the granules, leading to the release of TFPI in the plasma. ${ }^{\mathrm{B} A}$ The quantity of TFPI contained by platelets is only marginal compared to the fraction released by heparin and the fraction circulating in plasma. Nevertheless, at sites where platelets aggregate, the local concentration of TFPI can increase significantly. ${ }^{34}$ Summanizing, in vivo various fractions of TFPI occur. around $75 \%$ is bound to the vessel wall and released by heparin, $20 \%$ is bound to plasma lipoproteins, $2.5 \%$ circulates free in plasma, and $2.5 \%$ is contained by platelets (fig. 9 ). The physiological significance of the distribution of TFPI among these pools in the organism is not yet fully understood, and in part this thesis is an attempt to find clues to shed some light on this puzzle.

\subsubsection{Heparin cofactor II}

Heparin cofactor II ( $\mathrm{HCll})$ is a natural inhibitor of thrombin. HCll is a glycoprotein of $66 \mathrm{kDa}$ with a plasma concentration of $1.36 \mu \mathrm{M}$, and like AT it is a member of the protein superfamily of serpins $(\S 1.4 .1){ }^{65}$ in contrast to AT, HCIl inhibits thrombin only, it does not inhibit any other serine proteinases of the clotting cascade. Furthermore, HCll inhibits thrombin to a significant extent only in the presence of negatively charged glycosaminoglycans. The heparin binding domain of $\mathrm{HCll}$ and the mechanism of inhibition are similar to that of AT $(\$ 1.4 .1)$.

\subsection{5 $\alpha 2$-macroglobulin}

$\alpha$-Macroglobulins are a very ancient class of proteins, existing for over 600.000 .000 years, which is widely dispersed in both invertebrate and vertebrate species. ${ }^{58}$ These proteins are assembled from two or four identical subunits of $180 \mathrm{kDa}$, which have been highly conserved throughout evolution. Human 22 -macroglobulin is composed of four of these subunits, which are arranged in a large three-dimensional protein structure of $725 \mathrm{kDa}$ with an internal cleft. $\alpha$-Macroglobulins not only inhibit serine proteinases, but also 


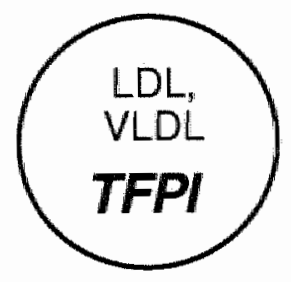

TFPI
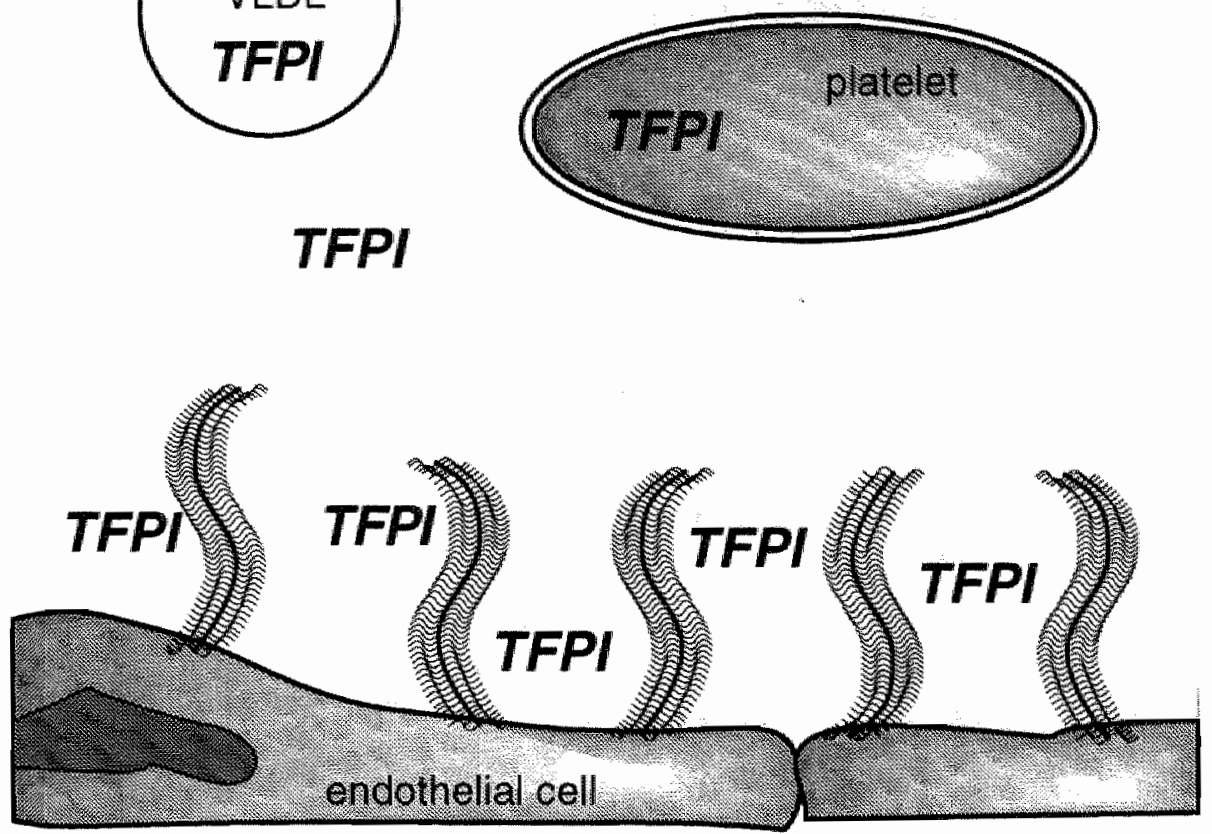

Figure 9. Distribution of the tissue factor pathway inhibitor (TFPl) in wivo. Around $75 \%$ is bound to glycosaminoglycans present on the vascular endothelium, $20 \%$ is bound to lipoproteins (mainby LDL and VLDL), $2.5 \%$ is found in platelets, and $2.5 \%$ is free.

proteinases of the other classes, i.e. cysteine, aspartic, and metallo proteinases. $\alpha$-Macroglobulins inhibit proteinases with a peculiar mechanism: in contrast to serpins and kunins they do not bind to the active site of the target proteinase, but "capture" the enzyme inside the internal cleft. The target proteinase hydrolyzes a bond in a domain called "bait"-region of the $\alpha$-macroglobulin. "Bait"-regions consist of about 25 amino acids, and are complementary to the specific target proteinases. Due to proteolysis of the "bait"-region a conformational change in the three-dimensional structure of the inhibitor is provoked, which closes the internal cleft, and the enzyme remains locked inside. ${ }^{86}$ This $\alpha$-macroglobulin - enzyme complex is then cleared from the circulation by receptor-mediated cellular internalization. Generally, $\alpha$-macroglobulins are less specific and less effective inhibitors than serpins and kunins, but due to the high plasma concentration of $2.9 \mathrm{mM}$, a substantial part $(-20 \%)$ of the physiological inhibition of thrombin is caused by $\alpha 2$-macroglobulin. Since $\alpha 2$-macroglobulin does not bind to the active site of the thrombin, small substrates, like the synthetic substrates used in functional chromogenic assays, still have access to the enzyme in the $\alpha 2$-macroglobulin - thrombin 
complex and are hydrolyzed, whereas proteolysis of larger substrates like fibrinogen, FV and other clotting factors is inhibited due to sterical hindrance. This effect has to be taken into account when analyzing the results of chromogenic assays of thrombin. ${ }^{87}$

\subsection{Natural anticoagulants and thrombotic disorders}

While genetic deficiency of the procoagulant factors causes inherited bleeding disorders (\$1.3), deficiency or reduced activity of one of the anticoagulant mechanisms can be the cause of inherited thrombotic disease. In some occasions the thrombotic episodes can be arterial, but usually the deficiency of natural anticoagulants is characterized by venous thrombosis (deep vein thrombosis of the upper or lower limbs), with pulmonary embolism or venous cerebral embolism as possible consequence. Venous thrombosis has an annual incidence of up to 1 in $1000 .{ }^{88}$ Analogous to hemophilia, the major bleeding disease caused by clotting factor deficiencies, inherited thrombotic disease is called thrombophilia. By definition, thrombophilia is characterized by at least two repeated episodes of venous thrombosis in an otherwise healthy and young ( $<40$ years) propositus, and at least one episode of venous thrombosis in a relative. The underlying inhibitor deficiency can be either quantitative, i.e. low plasma levels due to reduced gene-expression, or functional, i.e. a dysfunctional protein due to point-mutations or partial deletions with normal plasma levels. ${ }^{88.91}$

Deficiency of AT is a well described thrombophilic disorder. The AT plasma levels in a typical quantitative deficiency are around 40 to $70 \%$ of the normal levels, which complies with a heterozygous deficiency. Homozygous deficiency (plasma levels around 0 to $10 \%$ ) has never been found, and is probably incompatible with life. Various functional deficiencies have been described, which vary from point mutations in the substrate-like reactive site loop to partial deletions, and also a dysfunctional variant with mutations in the heparin binding domain of AT has been described. ${ }^{92.93}$

Also thrombophilia caused by deficiencies of PC and PS has been well documented. In addition to both heterozygous and homozygous quantitative deficiencies, various functional deficiencies of $P C$ and $P S$ have been reported. ${ }^{9.4} \mathrm{~A}$ particular variant of quantitative PS deficiency exists, with normal C4BP-bound PS levels $(\$ 1.4 .2)$, and reduced free PS. ${ }^{94}$ Recently, a new defect of the PC anticoagulant system has been found, which is a major cause of thrombophilia. Dahlbäck et al discovered the defect by observing that the addition of activated PC to plasma of some thrombophilic patients did not prolong the clotting time like it does when added to plasma of normal subjects, 
and therefore named it APC-resistance. ${ }^{95}$ Bertina et al subsequently discovered the genetical basis of this disease, and showed that at least $90 \%$ of APC-resistance is due to a single point-mutation ( $G \rightarrow A$ at nucleotide 1691) in the $F V$ gene. ${ }^{96}$ The mutant FV protein has a arginine (506) to glutamine substitution in the domain where APC hydrolyzes and inactivates this factor. This mutant FV is therefore resistant to inactivation by APC. Since the functional clotting assay of PS and that of APC-resistance are similar, many cases of APC-resistance have been misclassified as PS dysfunctional thrombophilia. ${ }^{97}$ The discovery of the FV point-mutation, easily detectable with restriction fragment analysis, has now resolved this issue.

Whereas the deficiencies of AT, PC and PS together explain only up to $15 \%$ of thrombophilia, APC-resistance alone has a prevalence of around $50 \%$ (fig. 10). ${ }^{88-91}$ At the present time, around $60-70 \%$ of all thrombophilic disorders can be explained with one (or a combination) of the above described biochemical defects as underlying process. This means that not less than $30-40 \%$ are still undefined and subject to present-day investigation. Previous studies have described mutations in the HCll gene, but these mutations were found with the same frequency in a normal asymptomatic population. ${ }^{98}$ Therefore, deficiency of $\mathrm{HCl}$ is not likely to cause thrombophilia, and the physiological significance of this inhibitor is dubious. No deficiency of $\alpha 2$-macroglobulin has ever been found, probably it would be incompatible with life. ${ }^{58}$ Research of possible deficiencies of thrombomodulin is extremely time-consuming, because thrombomodulin is a cellular protein and it can not be measured in a blood sample. Only future molecular biology studies of the thrombomodulin gene in thrombophilic patients might uncover a possible role of this protein in thrombophilia. Up to date, no deficiency of TFPI in thrombophilic patients has been described, but these studies were based on measuring levels of plasma TFPI only. ${ }^{99.100}$ Since

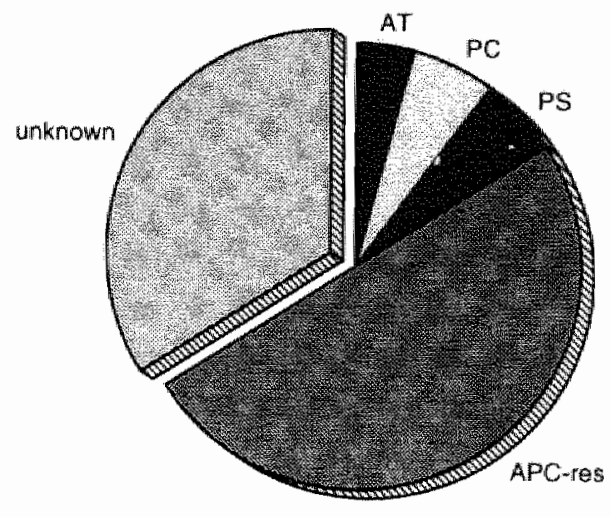

Figure 10. The prevalence of various coaguIation abnormalities in thrombophilic patients, Antithrombin (AT)-deficiency has a prevalence of around $4 \%$, protein $\mathrm{C}(\mathrm{PC})$-deficiency $6 \%$, protein S (PS)-deficiency $6 \%$ resistance to activated protein $\mathrm{C}$ (aPC-res) $50 \%$, and $34 \%$ of thrombophilia remains without a known underlying coagulation abnormality. 
plasma TFPI is only a small part of the total TFPI present in the organism, this pool might be of relatively little physiological significance. Chapter 4 of this thesis discusses the possibility of thrombophilia due to a deficiency of endothelium-associated TFPI.

\subsection{Aim of the studies}

The studies described in this thesis were undertaken to investigate the role of the tissue factor dependent pathway of coagulation in thrombotic disorders in vivo. To be able to interpret studies of components of the tissue factor coagulation pathway in groups of patients with various pathologies correctly, it is important to know if and, if so, how these components vary in a normal population. Therefore, we studied the effect of two major physiological variables, i.e. age and sex, on the plasma levels of the main enzyme of the tissue factor pathway (FV\|l) and its main inhibitor (TFPI) in a large group of 160 normal, healthy individuals (chapter 2).

The major fraction of the inhibitor of the tissue factor pathway is not found in the circulating blood, but is released in the blood after injection of heparin, and is probably bound to the iuminal face of the vessel wall. To investigate if tachyphylaxis of the heparin-induced release of TFPI occurs, we performed repeated injections of heparin in three healthy volunteers (chapter 3). Deficiencies of natural anticoagulants can lead to disorders of venous thrombosis. Up to date, no deficiency of TFPI associated with thrombosis has been found, but previous studies have been done on plasma TFPI only. Since heparin-releasable TFPI probably contributes significantly to the anticoagulant properties of the vascular endothelium, we decided to investigate if deficiencies of the heparin-releasable fraction of TFPI might induce juvenile thrombosis (chapter 4).

Venous thrombosis is a frequent complication in patients with the nephrotic syndrome and high proteinuria. Deficiencies of natural anticoagulants, due to urinary loss, are often found in patients with proteinuria. These acquired deficiencies are probably a major thrombogenic factor in the nephrotic syndrome. Therefore, the nephrotic syndrome is an in vivo model of venous thrombosis caused by deficiencies of natural anticoagulants. in chapter 5 we first studied the level of activation of the tissue factor pathway of coagulation in patients with the nephrotic syndrome, using novel assays of in vivo coagulation activation. We next investigated if proteinuria may lead to deficiency of TFPI, which might be one of the causes of thrombotic complications in these patients (chapter 6).

Ischemic heart disease is caused by atherosclerosis of coronary arteries. Rupture of the atherosclerotic plaques can lead to thrombosis and total occlusion of the artery, precipitating acute coronary syndromes such as myocardial 
infarction and unstable angina. However, not all plaques trigger thrombosis upon rupture; autopsies of subjects who died of non-cardiac causes often show the presence of ruptured plaques without thrombi. It has been hypothesized previously that TF present in the atherosclerotic plaque might play a critical role in triggering thrombosis upon rupture, but conclusive proof has not been provided by previous studies. The recently developed technique of directional coronary atherectomy has made it possible to excise and obtain the atherosclerotic plaque in a relatively little invasive procedure. To investigate if thrombosis after plaque rupture is determined by the TF content of the plaque, we measured TF antigen and activity in atherosclerotic plaque specimens extracted by means of directional coronary atherectomy from patients with myocardial infarction, unstable angina and stable angina (chapter 7 ).

A few relatively little invasive techniques that remove the atherosclerotic plaque in coronary arteries have been developed, and are now often used instead of the more invasive coronary bypass to treat patients with atherosclerosis and ischemic heart disease. However, these techniques (such as percutaneous transluminal coronary angioplasty or PTCA, rotational ablation with a diamond stud, directional coronary atherectomy and stent implantation) abrase and fracture the atherosclerotic plaque, and lead to the exposure of the highly thrombogenic atheroma core to the blood. Therefore, intensive treatment with drugs that inhibit coagulation and platelet aggregation are mandatory during these procedures to prevent acute thrombosis. To study if angioplastic remodelling of the stenosed artery may lead to release of TF in circulation, we measured TF levels in plasma samples obtained locally from the coronary artery immediately before and after PTCA, rotational ablation and stent implantation (chapter 8). Furthermore, we studied the effect of antithrombotic therapy with ticlopidine on TF plasma levels.

\section{References}

de Haen $\mathrm{C}$, Neurath $\mathrm{H}$, Teller DC. The phylogeny of trypsin-related serine proteases and their zymogens. New methods for the investigation of distant evolutionary relationships. J Mol Biol 1975; 92: 225-259

2 Patthy L. Evolution of the proteases of blood coagulation and fibrinolysis by assembly from modules. Cell 1985; 41: 657-663

3 Zur $M$, Nemerson $Y$. Tissue factor pathways of blood coagulation. In: Haemostasis and thrombosis. Second edition. Bloom AL, Thomas DP, eds. Churchill Livingstone, Edinburgh, UK 1987; pp 148-164

Vermeer $\mathrm{C}$. Gamma-carboxyglutamate-containing proteins and the vitamin K-dependent carboxylase. Biochem J 1990; 266: 625-636 
5 Poller L. Oral anticoagulant therapy. In: Haemostasis and thrombosis. Second edition. Bloom AL, Thomas DP, eds. Churchill Livingstone, Edinburgh, UK 1987; pp 870-885

6 Teitel JM, Bauer KA, Lau HK, Rosenberg RD. Studies of the prothrombin activation pathway utilizing radioimmunoassays for the $F 2 / F 1+2$ fragment and thrombin-antithrombin complex. Blood 1982; 59: 1086-1097

7 Bauer KA, Kass BL, ten Cate H, Bednareck MA, Hawiger JJ, Rosenberg RD. Detection of factor X activation in humans. Blood 1989; 74: 2007-2015

8 Bawer KA, Kass BL, ten Cate H, Hawiger Jلl, Rosenberg RD. Factor IX is activated in vivo by the tissue factor mechanism. Blood 1990 4: 731-736

9 Mari D, Mannucci PM, Coppola R, Bottasso B, Bauer KA, Rosenberg RD. Hypercoagulability in centenarians: the paradox of successful aging. Blood 1995; 85: 3144-3149

10 Merlini PA, Bauer KA, Oltrona L, Ardissino D, Cattaneo M, Belli C, Mannucci PM. Persistent activation of the coagulation mechanism in unstable angina and myocardial infarction. Circulation 1994; 90:61-8

11 Nemerson $\mathrm{Y}$. The phospholipid requirement of tissue factor in blood coagulation. J Clin Invest 1968; 47: 72-80

12 Nemerson $Y$. Tissue factor and hemostasis. Blood 1988; 71: 1-8

13 Drake DA, Morrissey $\mathrm{JH}$, Edgington TS. Selective cellular expression of tissue factor in human tissues. Am J Pathol 1989; 134: 1087-97

14 Wilcox IN, Smith KM, Schwartz SM, Gordon D. Localization of tissue factor in the normal vessel wall and in the atherosclerotic plaque. Proc Natl Acad Sci USA 1989; 86: 2839-43

15 Fuster V, Fallon JT, Nemerson Y. Coronary thrombosis. Lancet 1996; 348 (suppl): $57-s 10$

16 Brand K, Fowler BJ, Edgington TS, Mackman N. Tissue factor mRNA in THP-1 monocytic cells is regulated at both transcriptional and posttranscriptional levels in response to lipopolysaccharide. Mol Cell Biol 1991; 87: $2254-2258$

17 Donovan-Peluso M, George LD, Hasset AC. Lipopolysaccharide induction of tissue factor expression in THP-1 monocytic cells. $J$ Biol Chem 1994; 269: 1361-1369

18 Edwards RL, Rickles FR, Cronlund M. Abnormalities of blood coagulation in patients with cancer. Mononuclear cell tissue factor generation. J Lab Clin Med 1981; $98: 917-928$

$19 \sigma$ Sterud B, Flagsted T. Increased tissue thromboplastin activity in monocytes of patients with meningococcal infection, related to an unfavorable prognosis. Thromb Haemost 1983; 49: 5-12

20. Neri Serneri GG, Abbate R, Gori AM, Attansio M, Martini F, Giusti B, 
Dabazzi P, Poggesi L, Modesti PA, Trotta F, Rostagno C, Boddi M, Gensini GF. Transient intermittent lymphocyte activation is responsible for the instability of angina. Circulation 1992; 86: 790-797

$21 \varnothing$ sterud B. Factor VII and haemostasis. Blood Coag Fibrinol 1990; 1: 175-181

22 Banner DW, D'Arcy A, Chène $C$, Winkler FK, Guha A, Konigsberg WH, Nemerson $Y$, Kirchhofer $D$. The crystal structure of the complex of blood coagulation factor Vlla with soluble tissue factor. Nature 1996; 380:41-46

23 Radcliffe $R$, Nemerson $Y$. Activation and control of factor VII by activated factor $X$ and thrombin. J Biol Chem 1975; 250: 388-395

24 Seligsohn U, Østerud B, Brown SF, Griffin $\mathrm{JH}$, Rapaport SI. Activation of human factor VII in plasma and in purified systems. Role of activated factor IX, kallikrein, and activated factor XII. J Clin Invest 1979; 64: 1056-1065

25 Radcliffe R, Bagdasarian A, Colman R, Nemerson Y. Activation of bovine factor VII by Hageman factor fragments. Blood 1977; 50: 611-617

26 Kisiel W, Fujikawa K, Davie EW. Activation of bovine factor VII (proconvertin) by factor XIla (activated Hageman factor). Biochemistry 1977; 16: 4189-4149

27 Neuenschwander PF, Morrisey JH. Deletion of the membrane anchoring region of tissue factor abolishes autoactivation of factor VII but not cofactor function. J Biol Chem 1992; 267: 14477-14482

28 Morrisey JH, Macik BG, Neuenschwander PF, Comp PC. Quantitation of activated factor VII levels in plasma using a tissue factor mutant selectively deficient in promoting factor VII activation. Blood 1993; 81: 734-744

29 Duckert $F$, Fluckiger $P$, Koller $F$. Le role du facteur $X$ dans la formation de la tromboplastine sanguine. Revue D'Hematologie 1954; 9: 489-492

$30 \varnothing$ sterud B, Rapaport SI. Activation of factor $\mathrm{XX}$ by the reaction product of tissue factor and factor VII. Additional pathway for initiating blood coagulation. Proc Natl Acad Sci USA 1977; 74: 5260-5364

31 Zur $M$, Nemerson $Y$. Kinetics of bovine ${ }^{3} \mathrm{H}$-factor $\mathrm{IX}$ activation vie the extrinsic pathway. J Biol Chem 1980; 255: 5703-5707

32 Zur $M$, Nemerson $Y$. The esterase activity of coagulation factor VII: Evidence for intrinsic activity of the zymogen. J Biol Chem 1978; 253: 2203-2209

33 Zur M, Radcliffe RD, Oberdick J, Nemerson $Y$. The dual role of factor VII in blood coagulation. Initiation and inhibition of a proteolytic sytem by a zymogen. J Biol Chem 1982; 257: 5623-5631

34 Kario K, Miyata T, Sakata T, Matsu T, Kato H. Fluorogenic assay of activated factor VII: plasma factor VIla levels in relation to arterial cardiovascular diseases in Japanese. Arterioscler Thromb 1994; 14: 265-274. 
35 Marder VJ, Schulman NR. Clinical aspects of congenital factor VII deficiency. Am J Med 1964; 37: 182-194

36 Mariani G, Mazzucconi MG. Factor VII congenital deficiency: Clinical picture and classification of the variants. Haemostasis 1983; 13: 169-177

37 Telfer TP, Denson KW, Wright DR. A 'new' coagulation defect. Brit J Haematol 1956; 2 : 308-316

38 Hougie C, Barrow EM, Graham B. Stuart clotting defect 1. Segregation of an hereditary hemorrhagic state from a heterogenous group heretofore called 'stable factor' (SPCA, proconvertin, factor VII) deficiency. J Clin Invest 1957; 36: 485-496

39 Zimmerman TS, Meyer D. Structure and function of factor VIII and von Willebrand factor. In: Haemostasis and thrombosis. Second edition. Bloom AL, Thomas DP, eds. Churchill Livingstone, Edinburgh, UK 1987; pp 131-147

40 Bloom AL, Inherited disorders of blood coagulation. In: Haemostasis and thrombosis. Second edition. Bloom AL, Thomas DP, eds. Churchill Livingstone, Edinburgh, UK 1987; pp 393-436

41 Aronson DL. N-terminal amino-acids forrmed during the activation of prothrombin. Nature 1962; 194: 475-476

42 Owen W, Esmon C, Jackson C. The conversion of prothrombin to thrombin. I. Characterization of the reaction products formed during the activation of bovine prothrombin. J Biol Chem 1974; 249: 594-605

43 Hemker HC, Esnouf MP, Hemker PW, Swart ACW, Macfarlane RG. Formation of prothrombin converting activity. Nature 1967; 215: 248-251

44 Blomback B, Hogg DH, Gardlund B, Hessel B, Kudryk B. Fibrinogen and fibrin formation. Thromb Res 1976; 8 (Suppl II): 329-346

45 Schwartz ML, Pizzo SV, Hill RL, McKee PA. Human factor XII! from plasma and platelets. J Biol Chem 1973; 248: 1395-1407

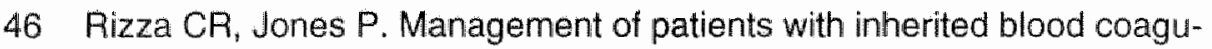
lation defects. In: Haemostasis and thrombosis. Second edition. Bloom AL, Thomas DP, eds. Churchill Livingstone, Edinburgh, UK 1987; pp 465.493

47 Gailani $D$, Broze GJ Jr. Factor XI activation in a revised model of blood coagulation. Science 1991; 253: 909-912

48 Naito $K_{x}$ Fujikawa $K$. Activation of human blood coagulation factor $X I$ independent of factor XII: Factor XI is activated by thrombin and factor Xla in the presence of negatively charged surfaces. J Biol Chem 1991; 266: $7353-7358$

49 Glueck HI, Roehll W Jr. Myocardial infarction in a patient with a Hageman (factor XII) defect. Amn Intern Med 1966; 64: 390 
50 Hoak JC, Swanson LW, Warner ED, Connor WE. Myocardial infarction associated with severe factor XII deficiency. Lancet 1966;2:884

51 Mcpherson RA. Thromboembolism in Hageman trait. Am $J$ Clin Pathol $1977 ; 68: 420$

52 Ratnoff $\mathrm{OD}_{n}$ Busse RJ $\mathrm{Jr}$, Sheon RP. The demise of John Hageman. N Engl J Med 1968; 279: 760

53 DeLa Cadena RA, Wachtfogel YT, Colman RW. Contact activation pathway: Inflammation and coagulation. In: Hemostasis and thrombosis: Basic principles and clinical practice. Third edition. Colman W, Hirsch J, Marder VJ, Salzman EW, eds. J.B. Lippincott Company, Philadelphia, USA 1994; pp 219-240

54 Abildgaard U. Binding of thrombin to antithrombin III. Scand J Clin Lab Invest 1969; 24: 23-27

55 Rosenberg RD, Damus PS. The purification and mechanism of action of human antithrombin-heparin cofactor. J Biol Chem 1973; 248: 6490-6505

56 Olds RJ, Lane DA, Mille B, Chowdhury V, Thein SL. Antithrombin: the principal inhibitor of thrombin. Semin Thromb Haemostas 1994; 20: 353-372

57 Damus PS, Hicks M, Rosenberg RD. Anticoagulant action of heparin. Nature 1973; 246: 355-357

58 Salvesen G, Pizzo SV. Proteinase inhibitors: $\alpha$-macroglobulins, serpins and kunins. In: Hemostasis and thrombosis: Basic principles and clinical practice. Third edition. Colman W, Hirsch J, Marder VJ, Salzman EW, eds. J.B. Lippincott Company, Philadelphia, USA 1994; pp 241-258

59 Kanost MR, Prasad SV, Wells MA. Primary structure of a member of the serpin superfamily of proteinase inhibitors from an insect, Manduca sexta. J Biol Chem 1989; 264: 965

60 Heygaard J, Rasmussen SK, Brandt A, Svendsen I. Sequence homölogy between barley endosperm protein $Z$ and protease inhibitors of the $\alpha$-antitrypsin family. FEBS Lett 1985; $180: 89$

61 Pickup DJ, Ink BS, Hu W, Ray CA, Joklik WK. Hemorrhage in lesions caused by cowpox virus is induced by a viral protein that is related to plasma protein inhibitors of serine proteases. Proc Natl Acad Sci USA 1986; 83: 7698

62 Pizzo SV, Mast AE, Feldman SR, Salvesen G. In vivo catabolism of $\alpha_{1}$-antichymotrypsin is mediated by the serpin receptor which binds $\alpha_{1}$-proteinase inhibitor, antithrombin III and heparin cofactor II. Biochim Biophys Acta 1988; 967: 158

63 Perlmutter DH, Glover GI, Rivetna M, Schasteen CS, Fallon RJ. Identification of a serpin-enzyme complex receptor on human hepatoma cells 
and human monocytes. Proc Natl Acad Sci USA 1990; 87: 3753-3757

64 Villaneuva GB. Predictions of the secondary structure of antithrombin I and the location of the heparin-binding site. J Biol Chem 1984; 25 s $2531-2536$

65 Esmon TC. The protein $C$ anticoagulant pathway. Arterioscler Throm 1992; 12: 135-145

66 Dahlbäck B. Protein S and C4b-binding protein: Components involved $\mathrm{i}$ the regulation of the protein $\mathrm{C}$ anticoagulant system. Thromb Haemo: 1991; 66: 49-61

67 Esmon CT, Owen WG. Identification of an endothelial cell cofactor $f($ thrombin-catalyzed activation of protein C. Proc Natl Acad Sci USA 198 78: 2249-2252

68 Broze GJ Jr, Miletich JP. Characterization of the inhibition of tissue fact in serum. Blood 1987; 69: 150-155

69 Rao LVM, Rapaport SI. Studies of a mechanism inhibiting the initiation t the extrinsic pathway of coagulation. Blood 1987; 69: 645-651

70 Hubbard AR, Jennings CA. Inhibition of the tissue factor-factor VII con plex: Involvement of factor Xa and lipoproteins. Thromb Res 1987; 4 527-537

71 Broze GJ Jr, Warren LA, Novotny WF, Higuchi DA, Girard JJ, Miletich JI The lipoprotein-associated coagulation inhibitor that inhibits the factr VIl-tissue factor complex also inhibits factor $\mathrm{Xa}$ : insight into its possib mechanism of action. Blood 1988; 71: 335-343

72 Warn-Cramer BJ, Rao LVM, Maki SL, Rapaport SI. Modifications extrinsic pathway inhibitor (EPI) and factor Xa that affect their ability interact and to inhibit factor Vila/tissue factor: evidence for a two-st $E$ model of inhibition. Thromb Haemost 1988; 60: $453-456$

73 Sandset PM. Tissue factor pathway inhibitor (TFPI) - an update. Haemo tasis 1996; 26 (Suppl 4): 154-165

74 Girard TJ, Warren LA, Novotny WF, Likert KM , Brown SG, Miletich JI Broze GJ Jr. Functional significance of the Kunitz-type inhibitory domair of lipoprotein-associated coagulation inhibitor. Nature 1989; 338:518-5x

75 Wesselschmidt R, Likert K, Huang Z, MacPhail "Broze GJ Jr. Structur requirements for tissue factor pathway inhibitor interactions with factor $>$ and heparin. Blood Coag Fibrinol 1993; 4: 661-669

76 Harenberg $J$, Malsch $\mathrm{R}$, Heene $\mathrm{DL}$. Tissue factor pathway inhibitc proposed heparin recognition region. Blood Coag Fibrinol 1995; 6: S5 S56

77 Novotny WF, Girard GJ, Miletich JP, Broze GJ Jr. Purification ar characterization of the lipoprotein-associated coagulation inhibitor fro 
human plasma. J Biol Chem 1989; 264: 18832-18837

78 Warn-Cramer BJ, Maki SL, Zivelin A, Rapaport SI. Partial purification and characterization of extrinsic pathway inhibitor (the factor Xa-dependent plasma inhibitor) of factor VIla/tissue factor. Thromb Res $1987 ; 48: 11.22$

79 Broze GJ Jr, Lange GW, Duffin KL, MacPhail L. Heterogeneity of plasma tissue factor pathway inhibitor. Blood Coag Fibrinol 1994; 5: 551-559

80 Petersen LC, Bjorn SE, Nordfang O. Effect of leukocyte proteinases on tissue factor pathway inhibitor. Thromb Haemost 1992; 67: 537-541

81 Higuchi DA, Wun TC, Likert KM, Broze GJ Jr. The effect of leukocyte elastase on tissue factor pathway inhibitor. Blood 1992; 79: 1712-1719

82 Sandset PM, Abildgaard U, Larsen ML. Heparin induces release of extrinsic coagulation pathway inhibitor (EPI). Thromb Res 1988; 50 : $803-813$

83 Lindah: AK, Sandset PM, Abildgaard U. The present status of tissue factor pathway inhibitor. Blood Coag Fibrinol 1992; 3: 439-449

84 Novotny WF, Girard TJ, Miletich JP and Broze GJ Jr. Platelets secrete a coagulation inhibitor functionally and antigenically similar to the lipoprotein-associated coagulation inhibitor. Blood 1988; 72: 2020-2025

85 Tollefsen DM. Insight into the mechanism of action of heparin cofactor II. Thromb Haemost 1995; 74: 1209-1214

86 Barrett AJ, Starkey PM. The interaction of $\alpha_{2}$-macroglobulin with proteinases. Biochem J 1973; 133: 709

87 Hemker $\mathrm{HC}_{3}$, Wielders $\mathrm{S}$, Kessels $\mathrm{H}$, Béguin $\mathrm{S}$. Continuous registration of thrombin generation in plasma, its use for the determination of the thrombin potential. Thromb Haemost 1993; 70:617-624

88 Lane DA, Mannucci PM, Bauer KA, Bertina RM, Bochkov NP, Boulyjenkov V. Chandy M, Dahlbäck B, Ginter EK, Miletich JP, Rosendaal FR, Seligsohn U. Inherited thrombophilia: Part 1. Thromb Haemost 1996; 76: 651-662.

89 Lane DA, Mannucci PM, Bauer KA, Bertina RM, Bochkov NP, Boulyjenkov V. Chandy M, Dahlbäck B, Ginter EK, Miletich JP, Rosendaal FR, Seligsohn U. Inherited thrombophilia: Part 2. Thromb Haemost 1996; 76: 824-834

90 De Stefano V, Finazzi G, Mannucci PM. Inherited thrombophilia: Pathogenesis, clinical syndromes, and management. Blood 1996; 87: 3531. 3544

91 Florell SR, Rodgers GM. Inherited thrombotic disorders: An update. Am J Hematol 1997; 54:53-60

92 Finazzi $G$, Caccia $R$, Barbui $T$. Different prevalence of thromboembolism in the subtypes of congenital antithrombin III deficiency: Review of 404 
cases. Thromb Haemost 1987; 58: 1094

93 Lane DA, Olds RJ, Boisclair M, Chowdhury V, Thein SL, Cooper DN, Blajchman M, Perry D, Emmerich J, Aiach M. Antithrombin III mutation database: First update. Thromb Haemost 1993; 70: 361-369

94 Reitsma PH, Bernardi F, Doïg RG, Gandrille S, Greengard JS, Ireland H, Krawczak M, Lind B, Long GL, Poort SR, Saito H, Sala N, Witt I, Cooper D. Protein $C$ deficiency: A database of mutations, 1995 update. Thromb Haemost 1995; 73: 876-889

95 Dahlbäck B, Carlsson M, Svensson PJ. Familial thrombophilia due to a previously unrecognized mechanism characterized by poor anticoagulant response to activated protein $\mathrm{C}$ : Prediction of a cofactor to activated protein C. Proc Natl Acad Sci USA 1993; 90: 1004-1008

96 Bertina RM, Koeleman BP, Koster T, Rosendaal FR, Dirven RJ, de Ronde $H$, van der Velden PA, Reitsma PH. Mutation in blood coagulation factor $V$ associated with resistance to activated protein C. Nature 1994; 369 : 64-67

97 Fäioni EM, Franchi $F$, Asti $D$, Sacchi E, Bernardi F, Mannucci PM. Resistance to activated protein $\mathrm{C}$ in nine thrombophilic families: interference in a protein S functional assay. Thromb Haemost 1993; 70 : $1067-1071$

98 Bertina RM, van der Linden IK, Engesser L, Muller HP, Brommer EJP. Hereditary heparin cofactor II deficiency and the risk of development of thrombosis. Thromb Haemost 1987; 57: 196-200

99 Novotny WF, Brown SG, Miletich JP, Rader DJ, Broze GJ Jr. Plasma antigen levels of the lipoprotein-associated coagulation inhibitor in patient samples. Blood 1991; 78: 387-393

100 Goodwin CA, Melissari E, Kakkar VV, Scully MF. Plasma levels of tissue factor pathway inhibitor in thrombophilic patients. Thromb Res 1993; 72: 363-366 


\section{Chapter 2}

The increase with age of the components of the tissue factor coagulation pathway is gender-dependent

Ariëns RAS, Coppola R, Potenza I, Mannucci PM. Blood Coag Fibrinol 1995; 6: $433-437$ 


\section{Abstract}

To evaluate the influence of age and gender on the components of the tissue factor coagulation pathway, plasma levels of tissue factor pathway inhibitor (TFPI), activated factor VII (FVIla) and factor VIl coagulant activity (FVIlc) were measured in 160 normal individuals. The female $(n=82)$ and male $(n=78)$ part of the population were matched for age, which was equally distributed from 21 to 101 years. Mean levels of TFPI were lower and those of FVIlc higher in women than in men; there was no gender-related difference for FVIla. Linear regression analysis showed a positive correlation between age and TFPI $(r=0.34, p=0.0001)$, FVIla $(r=0.36, p=0.0001)$ and FVIlc $(r=0.40, p=0.0001)$. For each measurement, the positive correlation with age was mainly contributed by the female part of the population (TFPI: $r=0.51, p=0.0001$; FVIla: $r=0.47$, $p=0.0001$; FVIIc: $r=0.58, p=0.0001$ ), whereas there was no significant correlation between age and TFPI, FVIla or FVIllc in males. The association of these measurements with gender was confirmed by comparing mean levels in the older than 55 years with those in the younger than 55 years. TFPI, FVIla and FVlic were much higher in the older women group $(P<0.0002)$, whereas in the male part of the population only FVIlc was slightly higher in the older group $(P=0.03)$. These results indicate that the increase with age of the components of the tissue factor pathway of blood coagulation is mainlly contributed by the female part of the normal population.

\section{Introduction}

Plasma factor VII is a vitamin K-dependent glycoprotein, that, when activated and complexed with tissue factor, forms the most important physiological trigger of blood coagulation, the tissue factor pathway. ${ }^{1}$ Factor VII activity is controlled by the tissue factor pathway inhibitor (TFPI), which first binds to activated factor $X$ and then inhibits activated factor VII (FVIIa). ${ }^{2.3}$ There is interest for the tissue factor coagulation pathway since the Northwick Park Heart Study has demonstrated that plasma levels of factor VII coagulant activity (FVIIC) in the upper tertile of the normal distribution are a good predictor for coronary heart disease (CHD). ${ }^{4}$ Since a new method measuring specifically FVIla has been developed using a mutant tissue factor, also FVIla has recently been reported to increase in cardiovascular disease. ${ }^{5}$ Likewise, recent studies showed that plasma TFPI levels are increased in patients with cardiovascular disease. ${ }^{6.7}$

The potential use of these measurements in the prediction of cardiovascular events requires knowledge of any variability associated with age and gender. In normal individuals, FVIlc correlates positively with age ${ }^{8,9}$ Recently, a large study of 705 healthy individuals demonstrated that also factor VII antigen 
correlates positively with age. ${ }^{10} \mathrm{~A}$ positive association with age has also been demonstrated for FVII $a^{5,14}$ and TFPI. ${ }^{12,13}$ Gender-related differences have been investigated for FVIIC ${ }^{8.9}$ and FVIla, ${ }^{5,11}$ but not for TFPI. To study the relation with age and gender of the principal regulator of the tissue factor coagulation pathway, we measured plasma levels of TFPl in 160 normal individuals of both sexes (age ranging from 21 to 101 years), in parallel with those of the main substrate and enzyme of the pathway (FVIlc and FVIla).

\section{Materials and methods}

\section{Materials}

Essentially fatty acid free bovine serum albumin and the venom Ancrod were purchased from Sigma Chemical Co. (St. Louis, MO, USA), the synthetic thrombin inhibitor 1-2581 and chromogenic substrate S-2222 from Chromogenix (Mölndal, Sweden). Bovine brain phospholipids (Thrombofax) were obtained from Ortho Diagnostic Systems (Milan, Italy), rabbit brain thromboplastin (Manchester Reagent) from Laboratori Baldacci (Pisa, Italy), and a truncated soluble form of recombinant tissue factor (TF1-218) was a gift of Dr. Y. Nemerson (Mount Sinai School of Medicine, New York, NY, USA). Bovine factor Xa $(10 \mathrm{U} / \mathrm{ml})$ was obtained from Boehringer Mannheim Italia (Milan, Italy), human factor X $(20 \mathrm{U} / \mathrm{ml})$ from Diagnostica Stago (Asnires, France), and recombinant factor Vila from Novo Nordisk (Gentofte, Denmark). The First International Standard Plasma for Factors II, VII, IX and X (code 84/665) was provided by the National Institute for Biological Standards and Control (Potters Bar, UK), and factor VII deficient plasma was obtained from a congenitally deficient patient with plasma FVII levels of less than $2 \mathrm{U} / \mathrm{dl}$ (antigen and coagulant activity).

\section{Blood sampling and processing}

Venous blood was collected in siliconated Vacutainer tubes (Beckton Dickinson, Milan, Italy) containing $0.13 \mathrm{M}$ trisodium citrate, nine parts of blood to one part of trisodium citrate. The samples were centrifuged at $2000 \mathrm{~g}$ for 15 minutes at room temperature to obtain platelet-poor plasma, frozen in aliquots in liquid nitrogen, and stored at $-80^{\circ} \mathrm{C}$ until analysis. Before measurement of TFPI activity, plasma samples were defibrinated with Ancrod $(0.35 \mathrm{U} / \mathrm{ml})$ ). Fresh plate et poor plasma from 50 healthy volunteers different from those investigated in this study ( 25 men and 25 women; mean age 36 years, range 18 - 60) was pooled, frozen in liquid nitrogen, stored in aliquots at $-80^{\circ} \mathrm{C}$, and used as reference plasma in the TFPI and FVIlc assay. 
Assay of tissue factor pathway inhibitor (TFPI)

TFPI activity was measured by a two-stage chromogenic assay modified after the method published by Sandset et al: ${ }^{13}$ In brief, defibrinated plasma samples, diluted $1 / 10,1 / 20$ and $1 / 40$, were incubated in a microtiter plate at $37^{\circ} \mathrm{C}$ for 30 minutes with thromboplastin (Manchester Reagent; $1 / 40$ final dilution), bovine factor Xa $(0.031 \mathrm{U} / \mathrm{ml})$, recombinant factor VIla $(0.25 \mu \mathrm{g} / \mathrm{ml}), 0.05 \mathrm{M}$ imidazole$\mathrm{HCl} \mathrm{pH} 7.3,0.1 \mathrm{M} \mathrm{NaCl}$ and $7.5 \mathrm{mM} \mathrm{CaCl} 2.25 \mu \mathrm{l}$ of this mixture was subsampled in another microtiter plate containing $150 \mu$ of thrombin inhibitor I-2581 (0.025 mM), chromogenic substrate S-2222 (0.4 mM), human factor $X$ $(0.1 \mathrm{U} / \mathrm{ml}), 0.04 \mathrm{M}$ Tris- $\mathrm{HCl} \mathrm{pH} 7.5,0.12 \mathrm{M} \mathrm{NaCl}$ and $8.5 \mathrm{mM} \mathrm{CaCl} 2$. After incubation for another 30 minutes at $37^{\circ} \mathrm{C}$, the reaction was stopped by addition of $100 \mu 150 \%$ acetic acid. All samples were assayed with and without factor $X$ in the second stage. Optical densities at $405 \mathrm{~nm}$ obtained by incubation without factor $X$ were subtracted from the values obtained by incubation with factor $X$, to eliminate the influence of carry-over of factor $X a$ from the first stage. Values were expressed in percentage of the reference pooled plasma.

\section{Assay of activated factor VII (FVIla)}

Activated factor VII was measured by a one-stage prothrombin time-based assay using an ACL-300R automated coagulation instrument from instrumentation Laboratories (Ascoli Piceno, Italy). The assay is specific for activated factor VII, because of the use of $T_{1-218}$, which, in contrast to full length tissue factor, is deficient in promoting activation of zymogen factor VII. ${ }^{11}$ A standard curve was made with recombinant factor V/la, and results were expressed in $\mathrm{ng} / \mathrm{ml}$.

\section{Assay of coagulant activity of factor VII (FVIIC)}

Coagulant activity of factor VII was measured by a standard one-stage clotting assay using thromboplastin (Manchester Reagent) and congenitally deficient plasma. ${ }^{1 / 4}$ The pooled reference plasma was calibrated against the First International Standard Plasma for Factors II, VII, IX and X, and values were expressed in $\mathrm{U} / \mathrm{dl}^{15}$

\section{Subjects}

Plasma was obtained from 160 healthy individuals ( 82 women and 78 men): bload donors, hospital staff members, and old people from a nursing home. Their ages varied from 21 to 101 years with a homogeneous distribution between men and women. None of the women included in this study were taking oral contraceptives, nor substitutive oestrogen preparations. Individuals older than 70 years were all ambulatory and self-sufficient, and healthy on the basis of the strict criteria set by the Senieur Protocol, which includes both physical examination and laboratory analysis. ${ }^{16}$ 


\section{Statistical analysis}

Results were elaborated with linear regression analysis and Student's unpaired two-tail t-test, using the StatView (BrainPower Inc, Callabasas, CA, USA) software package. Type l error was defined for $\alpha=0.05$ in all tests performed.

\section{Results}

\section{Distribution of age}

The adult population included in this study consisted in 160 healthy individuals covering a wide range of ages, from young to very old. Every decade between 20 and 100 years of age was represented by approximately 20 subjects, half men and half women, with a slightly higher number of subjects in the age groups of $20-30$ and $30-40$ years (fig. 11). Accordingly, when the population was split for gender, age was homogeneously distributed in both the male $(n=78)$ and female $(n=82)$ parts of the population.

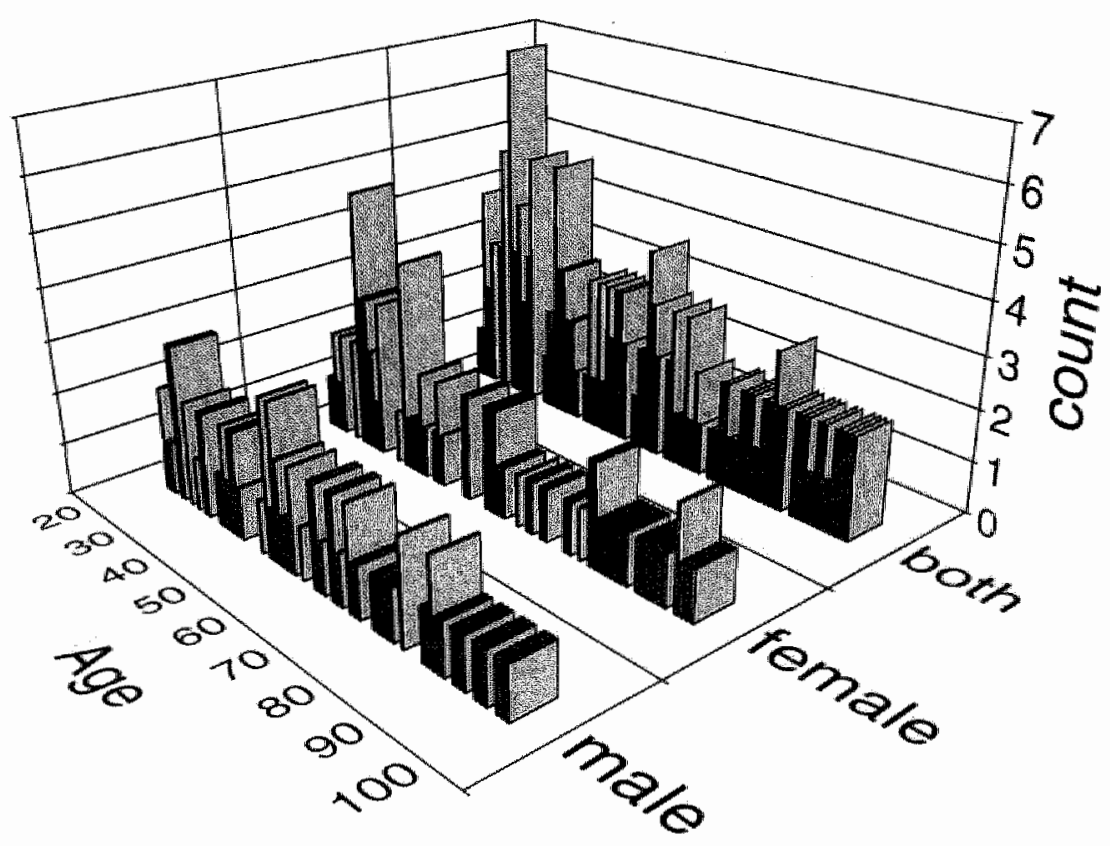

Figure 11. The distribution of age in the study population of 160 healthy individuals $(78 \mathrm{men}$ and 82 women).

\section{Gender-related differences}

In the whole population of 160 individuals, mean levels of TFPI were significantly lower in women than in men (Table 1). In contrast to TFPI, mean levels 
of FVlic were significantly higher in women than in men. Calculating a ratio of TFPI over FVIIC (TFPI/FVIIC), this ratio was less than one in the female part of the population (mean \pm SD: $0.96 \pm 0.17$ ), but more than one in the male part of the population $(1.12 \pm 0.24)$. Mean levels of FVlla did not differ significantly between women and men.

Table 1. Plasma levels of TFPI "FVlla and FVIlc (mean $\pm \mathrm{SD}$ ) in relation to gender and age.

\begin{tabular}{lccc}
\hline & $\begin{array}{c}\text { TFPI } \\
(\% \text { of pool })\end{array}$ & $\begin{array}{c}\text { FV/la } \\
(\mathrm{ng} / \mathrm{ml})\end{array}$ & $\begin{array}{c}\text { FV/lc } \\
(\mathrm{U} / \mathrm{dl})\end{array}$ \\
\hline $\begin{array}{l}\text { all women }(n=82) \\
\text { all men }(n=78)\end{array}$ & $105 \pm 19$ & $3.4 \pm 1.4$ & $111 \pm 22$ \\
$P$ women vs men & $111 \pm 20$ & $3.2 \pm 1.1$ & $101 \pm 14$ \\
women $\leq 54$ years $(n=41)$ & 0.04 & $n .5$. & 0.001 \\
women $\geq 55$ years $(n=41)$ & $95 \pm 15$ & $2.8 \pm 1.1$ & $99 \pm 17$ \\
$P$ older vs younger women & $115 \pm 19$ & $3.9 \pm 1.4$ & $123 \pm 20$ \\
& 0.0001 & 0.0002 & 0.0001 \\
men $\leq 54$ years $(n=37)$ & & & \\
men $\geq 55$ years $(n=41)$ & $108 \pm 20$ & $3.0 \pm 1.0$ & $98 \pm 13$ \\
Polder vs younger men & $114 \pm 20$ & $3.4 \pm 1.1$ & $105 \pm 14$ \\
\hline
\end{tabular}

n.s. denotes non significant differences (unpaired two-tail titest)

\section{TFPl, FVIla, FVIlc correlate with age in women only}

Linear regression analysis showed a statistically significant positive association between age and TFPI $(r=0.34, P=0.0001)$, FVIla $(r=0.36, P=0.0001)$ and FVIlc $(r=0.40, P=0.0001)$ in the whole population $(n=160)$. When the femalle part of the population was analyzed separately, the correlation coefficients between measurements and age were even higher than in the whole population (TFPI: $r=0.51, P=0.0001$, FVlla: $r=0.47, P=0.0001$ and FVIlc: $r=0.58, P=$ 0.0001 ) (fig. 12), whereas there was no statistically significant association between age and TFPI, FVIla nor FVIlc in the male part of the population (fig. 12).

Splitting the population in a younger and older group by a cutoff point set arbitrarily at age 55, mean levels of TFPI, FVIla, and FVIllc were significantly higher in the female older group compared to the younger group (table 1). These results are consistent with the finding of a positive association with age found in women using linear regression analysis. In the male part of the population only FVIlc was slightly higher in the older compared to the younger group $(P=$ 0.03 ). 

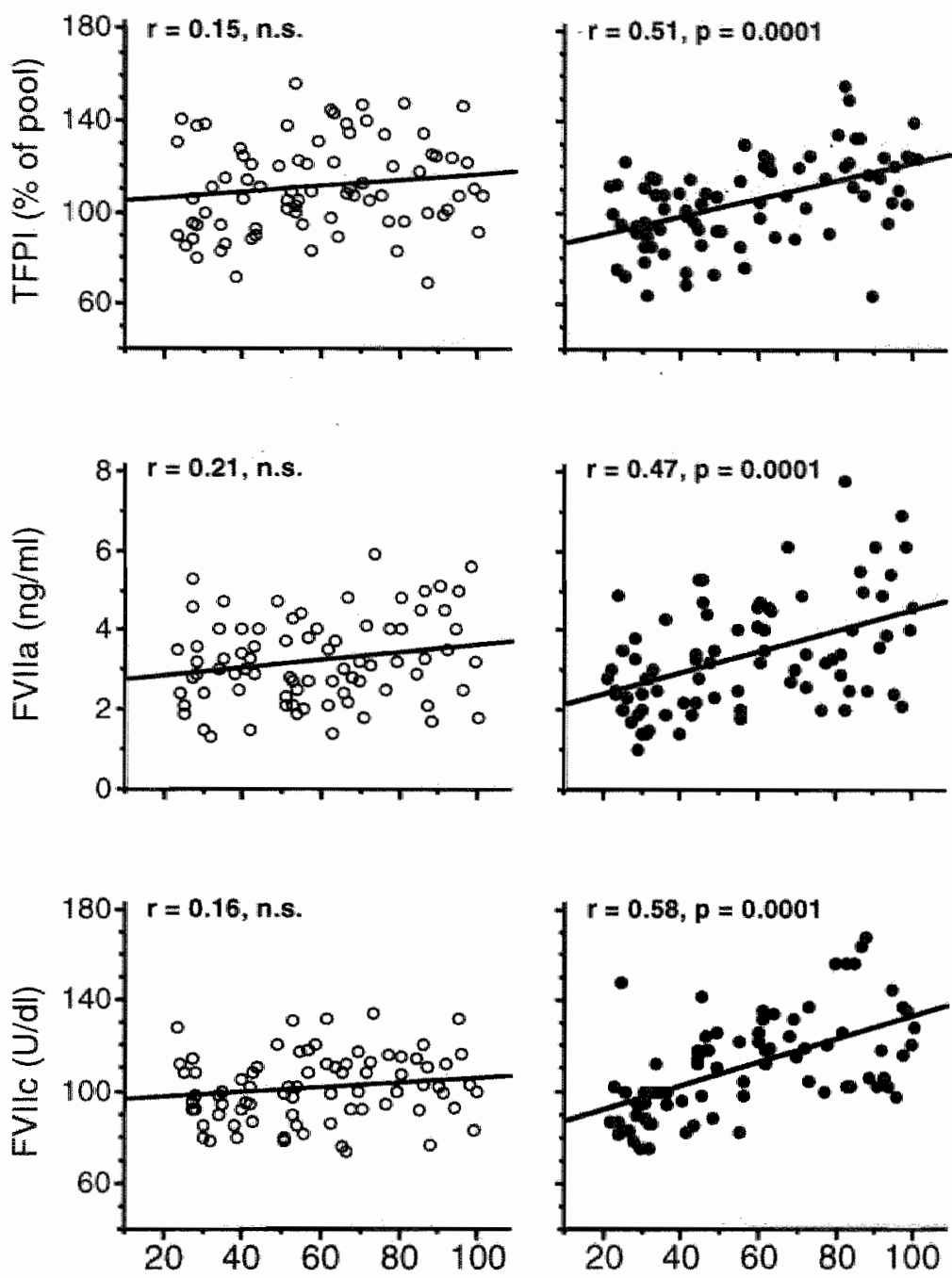

Age (years)

Figure 12. The association of age with TFPl, FVlla and FVIIC in normal individuals. Open circles represent men $(n=78)$ and closed circles represent women $(n=82)$. Correlation coefficients were obtained by linear regression analysis. n.s. denotes non significance $(P>0.05)$.

\section{Discussion}

The results of plasma levels of the components of the tissue factor pathway are difficult to interpret. In physiological conditions, tissue factor (the cofactor of this pathway) is localized extravascularly. ${ }^{17}$ Since FVIla has very high affinity 
for tissue factor ${ }^{17}$ and only trace amounts of FVII are activated in normal conditions," one can imagine that if any tissue factor comes in contact with blood, the level of FVlla measured in circulating blood is only a small fraction of that complexed with tissue factor and exerting its cofactor activity. Hence, plasma FVIla levels can be expected to measure only a small fraction of the enzyme available. In addition "TFPI in vivo exists in several pools: approximately $75 \%$ is released into circulation after injection of heparin, $20 \%$ circulates in blood bound to lipoproteins, $2.5 \%$ circulates free, and $2.5 \%$ is found in platelets. ${ }^{18}$ Therefore, plasma TFPI (bound to lipoproteins or free) is only a small part of the total TFPI present in the organism, and the physiological significance of this pool found in plasma remains to be fully understood. Moreover, whereas heparin-releasable TFPI is the full-length molecule, ${ }^{19}$ TFPI found in plasma is heterogeneous in molecular weight: only a fraction is full-length, the majority being truncated at the carboxy-terminus to a variable extent. ${ }^{20}$ These truncated forms are considerably less anticoagulant than full-length TFPI in one-stage bioassays, but have the same activity in endpoint chromogenic assays (like the assay used in this study). ${ }^{21,22}$ For all the forementioned reasons, defining the status of the tissue factor coagulation pathway solely by measuring the plasma levels of its components may provide limited information. Nevertheless, plasma levels of FVIlc have proven to be an important tool in cardiovascular medicine, and levels of TFPI and FVIla might prove to be likewise. Therefore, knowledge of variations of the plasma levels of FVII and TFPI in physiologically normal conditions is indispensable.

In agreement with previous findings of Sandset et $a l^{13}$ and Warr et $a l^{12}$ we found that TFPI, the principal inhibitor of the tissue factor pathway of coagulation, increases with age. Furthermore, we made the new observation that the correlation between age and TFPI is mainly supported by the increase occuring in women, with little contribution from the malle part of the population. In addition, our study confirms that FVIlc and FVIla are positively correlated with age in women, ${ }^{5.89 .11}$ whereas in men we observed that the association between age and FVIIc or FVIla was weak and failed to reach the levels of statistical significance.

Plasma levels of TFP|, like those of FVIla and FVIIC, were significantly higher in women older than 55 years of age compared to younger women. In men, only FVIIc resulted to be slightly higher in the group older than 55 . Since it has been suggested that hormonal changes induced by the menopause increase plasma levels of activated factor $V 11,{ }^{8,10,23}$ possibly also TFPI is influenced by the menopause in a similar way.

Like Kario et al, we found higher levels of FVIlc in women than those in men, ${ }^{9}$ and we did not find gender-related differences for FVIlla. Interestingly, 
whereas FVIlc is higher in women, we found TFPI higher in men. Therefore, the ratio of plasma levels of TFPI over FVIlc was less than one in women, whereas this ratio was more than one in men. These findings suggest that a procoagulant imbalance of the tissue factor pathway of coagulation exists in healthy women, while an anticoagulant imbalance of this pathway prevails in healthy men.

In conclusion, this study shows that the positive correlation between age and measurements of the tissue factor pathway is mainly supported by the values obtained in women. Plasma levels of TFPI tend to parallel those of FVII and correlate more with age in women than in men.

Acknowledgements - This work was supported in part by CNR, Progetto Finalizzato FATMA. The authors wish to thank $G$. Alberio for technical support, and P. Cristilli for useful and pleasant discussions. R. A. S. Ariëns was supported by a grant from the Angelo Bianchi Bonomi Foundation.

\section{References}

1 Rapaport SI, Rao LVM. Initiation and regulation of tissue factor-dependent blood coagulation. Arterioscler Thromb 1992; 12: 1111-1121.

2 Broze GJ, Warren LA, Novotny WF, Higuchi DA, Girard JJ, Miletich JP. The lipoprotein-associated coagulation inhibitor that inhibits the factor VII-tissue factor complex also inhibits factor $\mathrm{Xa}$ : insight into its possible mechanism of action. Blood 1988; 71: 335-343.

3 Warn-Cramer BJ, Rao LVM, Maki SL, Rapaport SI. Modifications of extrinsic pathway inhibitor (EPI) and factor Xa that affect their ability to interact and to inhibit factor VIla/tissue factor: evidence for a two-step model of inhibition. Thromb Haemost 1988; 60: 453-456.

4 Meade TW, Mellows S, Brozovic M, Miller GJ, Chakrabarti RR, North WRS, Haines AP, Stirling $Y$, Imeson JD, Thompson SG. Haemostatic function and ischaemic heart disease: principal results of the Northwick Park Heart Study. Lancet 1986; 2: 533-537.

5 Kario K, Miyata T, Sakata T, Matsu T, Kato H. Fluorogenic assay of activated factor VII: plasma factor VIla levels in relation to arterial cardiovascular diseases in Japanese. Arterioscler Thromb 1994; 14: 265-274.

6 Sandset PM, Sirnes PA, Abildgaard U. Factor VII and extrinsic pathway inhibitor in acute coronary disease. Br J Haematol 1989; 72: 391-396.

7 Moor E, Hamsten A, Karpe F, Båvenholm $P$, Blombäck $M$, Silveira A. Relationship of tissue factor pathway inhibitor activity to plasma lipoproteins and myocardial infarction at a young age. Thromb Haemost 1994; 71: $707-712$. 
8 Balleisen L, Bailey $\downarrow$, Epping $\mathrm{PH}$, Schulte $\mathrm{H}_{*}$ van de Loo J. Epidemiological study on factor VII, factor VIII and fibrinogen in an industrial population: I Baseline data on the relation to age, gender, body weight, smoking, alcohol, pill-using and menopause. Thromb Haemost 1985; 54:475-479.

9 Kario K. Takefumi M, Nakao K. Factor VIll hyperactivity in the elderly. Thromb Haemost 1991; 65: 25-27.

10 Howard PR, Bovill EG, Pike J, Church WR, Tracy RP. Factor VII antigen levels in a healthy blood donor population. Thromb Haemost 1994; 72: 21-27.

11 Morrisey JH, Macik BG, Neuenschwander PF, Comp PC. Quantitation of activated factor VII levels in plasma using a tissue factor mutant selectively deficient in promoting factor VII activation. Blood 1993; 81: 734-744.

12 Warr TA, Warn-Cramer BJ, Rao LVM, Rapaport SI. Human plasma extrinsic pathway inhibitor activity: I Standardization of assay and evaluation of physiologic variables. Blood 1989; 74: 201-206.

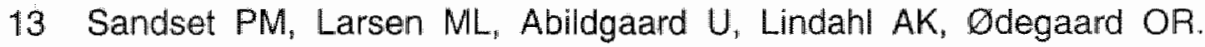
Chromogenic substrate assay of extrinsic pathway inhibitor (EPI): levels in the normal population and relation to cholesterol. Blood Coag Fibrinol 1991; 2: 425-433.

14 Poggio M, Tripodi A, Mariani G, Mannucci PM. Factor VII clotting assay: influence of different thromboplastins and factor VII-deficient plasmas. Thromb Haemost 1991; 65: 160-164.

15 Barrowcliffe T. Standardization of factors II, VII, IX, X in plasma and concentrates. Thromb Haemost 1988; 59: 334.

16 Ligthart GJ, Corberomd JX, Foumier C, Galamaud P, Hijmans W, Kennes B, Muller-Hermelink HK, Steinmann GC. Admission criteria for immunogerontological studies in man: the Senieur protocol. Med Ageing Dev 1994; 28:47-55.

17 Nemerson $Y$. The tissue factor pathway of blood coagulation. Semin Hematol 1992; 29: 170-176.

18 Lindahl AK, Sandset PM, Abildgaard $U$. The present status of tissue factor pathway inhibitor. Blood Coag Fibrinol 1992; 3: 439-449.

19 Novotny WF, Palmier M, Wun T-C, Broze GJ, Miletich JP. Purification and properties of heparin-releasable lipoprotein-associated coagulation inhibitor. Blood 1991; 78: 394-400.

20 Broze GJ, Lange GW, Duffin KL, MacPhail L. Heterogeneity of plasma tissue factor pathway inhibitor. Blood Coag Fibrinol 1994; 5: 551-559.

21 Nordlang $O$, Bjørn SE, Valentin S, Nielsen LS, Wildgoose P, Beck TC, Hedner $U$. The $C$-terminus of tissue factor pathway inhibitor is essential to its anticoagulant activity. Biochemistry 1991; 30: 10371-10376. 
22 Wesselschmidt R, Likert KM, Girard TJ, Wun T-C, Broze GJ. Tissue factor pathway inhibitor: the carboxy-terminus is required for optimall inhibition of factor Xa. Blood 1992; 79: 2004-2010.

23 Scarabin PY, Bonithon-Kop C, Bara L, Malmejac A, Guize L, Samama M. Factor VIII activation and menopausal status. Thromb Res 1990; 57: 227-234. 


\section{Chapter 3}

Repeated Release of the Tissue Factor Pathway Inhibitor

Ariëns AAS, Faioni EM, Mannucci PM. Thromb Haemost 1994; 72: 327-328 
Sir,

The Tissue Factor Pathway Inhibitor (TFPI, previously known as $L A C l$ or EPI) is the main regulator of the factor VIla/tissue factor pathway. Intravenous injection of heparin induces a substantial release of TFPI, so that the circulating levels of this inhibitor augment immediately two to four times above pre-heparin levels. TFPI is also released after subcutaneous injection of heparin and low molecular weight heparin. ${ }^{1}$ Since the levels of released TFPI are closely related to heparin levels, the release after subcutaneous injection is less immediate and more prolonged.

TFPI contains a highly positively charged carboxy-terminus, ${ }^{2}$ and it is currently thought that this region is important for binding to negatively charged glycosaminoglycans including heparin. Venous occlusion does not increase TFPl levels in circulation. ${ }^{1}$ Moreover, reagents inducing exocytosis of granular proteins from the endothelium (like desmopressin releasing von Willebrand factor), do not induce release of TFPI. ${ }^{3}$ The heparin-releasable pool is therefore thought to be TFPI bound to glycosaminoglycans present on the luminal surface of the endothelium. Injected heparin probably displaces the inhibitor from endothelial glycosaminoglycans, releasing it into circulation. When heparin is eliminated, released TFPI very likely reattaches to the endothelium. Supporting this hypothesis, previous studies have shown that there is no depletion of the heparin releasable pool of TFPI, when heparin is administered intravenously 3 times at intervals of $4 \mathrm{~h}$, the time of removall of the drug from circulation. ${ }^{4}$ To confirm and extend these studies, we performed 8 repeated injections spread out over 5 days, administering one injection on day 1 and day 5 , and two injections on days 2 to 4 (one in the morning and one in the evening).

$7500 \mathrm{IU}$ of unfractionated heparin were injected in the same antecubital vein from which the pre-heparin sample was taken. Post-heparin samples were taken 10 minutes after injection from the other arm. TFPI activity was measured in a two-stage chromogenic assay modified after the method published by Sandset et $a l^{5}$ All samples were measured with and without factor $X$ in the second stage, and optical densities from the incubation without factor $X$ were subtracted from the values obtained with the incubation in the presence of factor $X$, to eliminate optical density caused by carry-over of factor $X a$ from the first stage.

Repeated intravenous injections of $7500 \mathrm{IU}$ of unfractionated heparin in 3 normal individuals showed no decrease in the release of TFPI. Figure 13 exemplifies 8 repeated injections given with time intervals of 9 to $19 \mathrm{~h}$ in one volunteer. Each bolus induced a similar release of TFPI, and after each bolus levels returned to normal. The coefficients of variation of pre-and post-heparin 


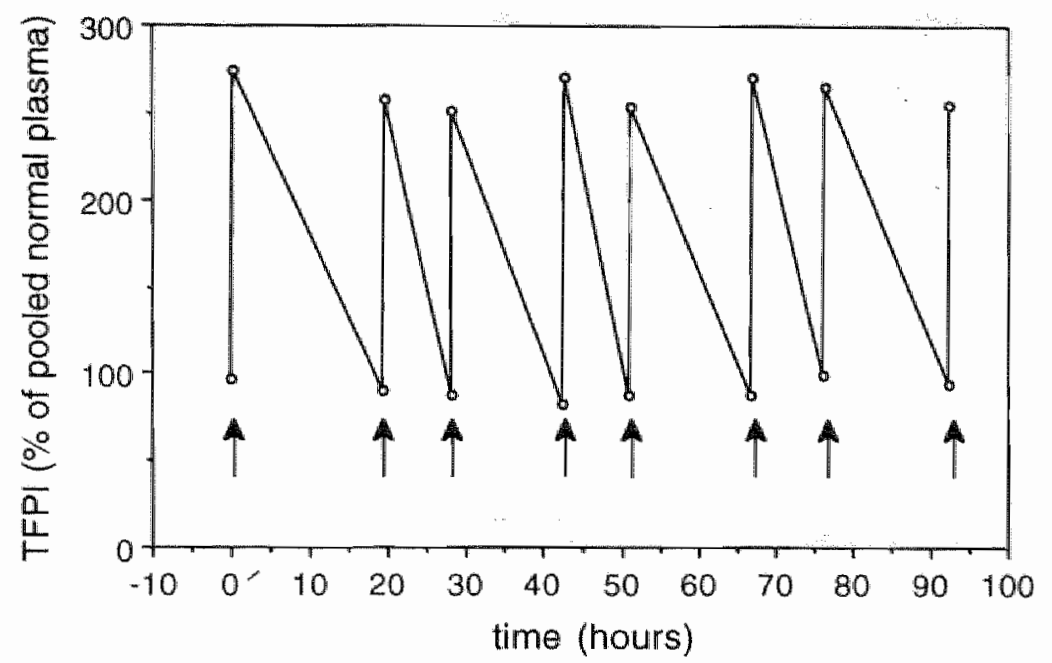

Figure 13. TFPI levels after repeated intravenous injections of 7500 IU unfractionated hepanin (indicated by wertical arrows) in one normal individual. Mean \pm S.D. was $90 \% \pm 6$ for pre-heparim lewels, and $262 \%$ t 9 tor post-heparin levels.

levels ( $6 \%$ and $4 \%$ respectively) were very close to the within assay coefficient of variation $(5 \%)$. Although little is known about the synthesis of TFPl, these results are in line with the hypothesis of no tachyphylaxis for the heparin-induced release of TFPI, and the hypothesis of displacement of TFPI from glycosaminoglycans on the endothelium.

\section{References}

1 Sandset $P M$, Abildgaard $U_{1}$ Larsen ML. Heparin induces release of extrinsic coagulation pathway inhibitor (EPI). Thromb Res 1988; 50: 803-13.

2 Wun TC, Kretzmer KK, Girard TJ, Miletich JP, Broze GJ Jr. Cloning and characterization of a cDNA coding for the lipoprotein-associated coagulation inhibitor shows that it consists of three tandem Kunitz-type inhibitory domains. J Biol Chem 1988; 263: 6001 4.

3 Warr TA, Warn-Cramer BJ, Rao LVM, Rapaport SI. Human plasma extrinsic pathway inhibitor activity: I. Standardization of assay and evaluation of physiological variables. Blood 1989; 74: 201-6.

4 Lindahl AK, Sandset PM, Abildgaard U. The present status of tissue factor pathway inhibitor. Blood Coag Fibrinol 1992; 3: 439-49.

5 Sandset PM, Abildgaard U, Pettersen M. A sensitive assay of extrinsic coagulation pathway inhibitor (EPI) in plasma and plasma fractions. Thromb Res 1987; 47: 389-400. 


\section{Chapter 4}

Low levels of heparin-releasable tissue factor pathway inhibitor in patients with juvenile thrombosis

Ariëns RAS, Alberio G, Moia Mr Mannucci PM. Submitted for publication 


\section{Abstract}

Deficiency of tissue factor pathway inhibitor (TFPI) has not yet been clearly demonstrated in patients with thrombosis, but previous studies have been focused on plasma TFPI, which is only a small part of the total body TFPI. The major fraction of this natural anticoagulant can be measured in plasma after release by heparin injection. To investigate if deficiency of heparin-releasable TFPI might be associated with thrombosis, we measured TFPI before and 10 minutes after intravenous injection of $7500 \mathrm{IU}$ unfractionated heparin in 64 patients with juvenile venous thrombosis, 49 patients with juvenile arterial thrombosis and 38 normal individuals. Post-heparin TFPl activity levels were significantly lower in patients with venous thrombosis than in controls (mean \pm SD: $230 \% \pm 39$ vs $260 \% \pm 34, p=0.0002$ ). Defining the normal range as mean $\pm 2 S D$ of TFPI activity levels in controls, twelve patients had low post-heparin TFPI activity levels, seven with venous and five with arterial thrombosis. These low levels were confirmed by immuno-assay in six of the seven patients with venous thrombosis and two of the five patients with arterial thrombosis. The low levels of heparin-releasable TFPI were not transient, and were present in at least one first degree relative of six patients. These results suggest that low levels of heparin-releasable TFPI might be inheritable. The causative role of low heparin-releasable TFPI remains uncertain, because co-segragation of the defect with thrombotic symptoms could not be established in the families studied.

\section{Introduction}

The tissue factor pathway inhibitor (TFPI) is the main inhibitor of the factor VIla/tissue factor pathway of blood coagulation. ${ }^{1-3}$ TFPI first binds and ir hibits factor $\mathrm{Xa}$ in a calcium-independent manner, and then forms a quaternary inhibitory complex involving factor $\mathrm{Xa}$, factor VIlla and tissue factor in the presence of calcium. ${ }^{4.5}$ In vivo, the inhibitor is located in at least 4 pools: approximately $75 \%$ is released into the circulation after injection of heparin, ${ }^{6} 20 \%$ circulates in blood bound to lipoproteins, ${ }^{7} 2.5 \%$ circulates free, and $2.5 \%$ is found in platelets. ${ }^{8}$ TFP contains a highly positively charged carboxy-terminus, ${ }^{9}$ and the heparin-releasable pool is thought to be TFPI bound to negatively charged glycosaminoglycans present on the luminal surface of the endothelium, displaced by injected heparin and released into the circulation. When heparin is cleared, released TFPI very likely reattaches to the endothelium and therefore the inhibitor can be released repeatedly. ${ }^{3: 10}$ However, intensive heparin therapy sometimes results in the depletion of the heparin-releasable pool. ${ }^{11,12}$ 
Notwithstanding the fact that the tissue factor pathway of coagulation plays an important physiological role, ${ }^{13}$ and that TFPI efficiently blocks the enzymes of this pathway, no inherited deficiency in plasma levels of TFPI, analogous to deficiencies of the other natural anticoagulants protein $\mathrm{C}$, protein $S$ and antithrombin, has hitherto been found in patients with a history of venous thrombosis. ${ }^{8,15}$ Low plasma levels of TFPI have been found in patients with abeta- and hypobetalipoproteinemia. The release of TFPI after injection of heparin, however, is normal, ${ }^{14}$ and patients with abeta- or hypobetalipoproteinemia do not experience thrombotic complications. Hence, the plasma pool of TFPI might be of less importance for protection against thrombosis than the heparin-releasable pool. In addition, plasma levels of TFPI (lipoprotein-bound and free) constitute only approximately $22.5 \%$ of the total levels. After intravenous injection of heparin, both heparin-releasable and circulating TFPI are measured, which, neglecting the TFPI contained in platelets (approximately $2.5 \%$ ), can be considered the total body TFPI. Since searches for TFPI deficiency have so far been focused on plasma levels of TFPI, we studied TFPI levels after heparin injection, which might be more sensitive than the measurement of the baseline TFPI levels to identify deficiencies of this natural anticoagulant in patients with juvenile thrombosis.

\section{Patients and methods}

\section{Patients}

One hundred and thirteen patients, consecutively referred to our thrombosis center for a recent or past-history of venous $(n=64)$ or arterial $(n=49)$ thrombosis, were studied, provided they met the following pre-established criteria: written informed consent, at least one thrombotic episode before age 45, no thrombotic episode in the last 3 months, no hemorrhagic diathesis, no hemorrhage in the central nervous system in the last 6 months, no surgery in the last 10 days, no oral anticoagulant therapy in the last month, no heparin therapy in the last 15 days, no allergy to heparin. Other criteria for inclusion were the absence of abnormalities in laboratory tests for lupus anticoagulant (Kaolin clotting time), anticardiolipin antibodies (antigenic assay), antithrombin (antigen and functional assays), protein $\mathrm{C}$ (antigenic, functional chromogenic and clotting assays), protein $S$ (bidimensional electrophoresis, antigenic, functional and PEG-precipitation assays), and resistance to activated protein $\mathrm{C}$ (functional clotting assay and PCR analysis of the Arg (506) - Glu mutation). Thrombotic episodes were confirmed with objective diagnostic methods (venography "pulmonary scintigraphy, computerized cerebral tomography). Twenty six family members, who gave written informed consent, were also studied. 
Thirty eight healthy members of the hospital staff ( 16 men and 22 women, mean age $\pm S D=35 \pm 8$ ) gave informed consent and were studied as the control population.

\section{Blood sampling and processing}

Venous blood was collected in siliconated Vacutainer tubes (Beckton Dickinson, France) containing $0.13 \mathrm{M}$ trisodium citrate, nine parts of blood to one part of trisodium citrate. The samples were centrifuged at $2000 \mathrm{~g}$ for 15 minutes at room temperature to obtain platelet-poor plasma. Aliquots of $500 \mu \mathrm{l}$ of plasma were frozen in liquid nitrogen, and stored at $-80^{\circ} \mathrm{C}$ until analysis. All plasma samples were defibrinated before measurement of TFPI activity: $3.5 \mu$ of ancrod (Sigma Chemical Co., St. Louis, MO; $0.35 \mathrm{U} / \mathrm{ml}$ final) was gently mixed with $500 \mu \mathrm{l}$ of plasma, and incubated at $37^{\circ} \mathrm{C}$ for 20 minutes. The fibrin clot was discarded by winding it on a small wooden toothpick. One lot of freshly pooled normal plasma from 40 healthy individuals was defibrinated, frozen in liquid nitrogen, stored at $-80^{\circ} \mathrm{C}$ in small aliquots, and used as reference plasma throughout the study.

\section{Heparin injection}

Unfractionated heparin (Liquemin Roche, Milan, Italy; 7500 IU) was injected in the same antecubital vein from which the pre-heparin sample was taken. Post-heparin samples were taken from the other arm. A detailed time course of TFPI released by heparin was obtained in four normal individuals, taking samples at 2, 4, 6, 10,15,30,60,120 and 180 minutes after heparin injection. After having established the peak of post-heparin TFPI response (see Results), post-heparin samples of all subjects enroled in the study were obtained 10 minutes after injection.

\section{TFPl activity assay}

TFPI activity was measured with a two-stage chromogenic assay. Defibrinated plasma samples, diluted $1 / 10,1 / 20$ and $1 / 40$ (or $1 / 20,1 / 40$ and $1 / 80$ for post-heparin samples) were incubated in a microtiter plate at $37^{\circ} \mathrm{C}$ for 30 minutes with recombinant human tissue factor (Ricombiplastin, Ortho Diagnostic Systems, Milan, Italy; final dilution 1/60), recombinant activated factor VIII (Novo Nordisk, Gentofte, Denmark; $0.19 \mu \mathrm{g} / \mathrm{ml}$ ), human activated factor $X$ (Diagnostica Stago, Asnières, France; $0.125 \mu \mathrm{g} / \mathrm{ml}$ ), $0.05 \mathrm{M}$ imidazole- $\mathrm{HCl} \mathrm{pH}$ $7.3,0.1 \mathrm{M} \mathrm{NaCl}$ and $7.5 \mathrm{mM} \mathrm{CaCl} 2$. Twenty five $\mu$ of this mixture were subsampled in another microtiter plate containing $150 \mu \mathrm{l}$ of the following combined reagent: $0.025 \mathrm{mM}$ thrombin inhibitor $1-2581,0.5 \mathrm{mM}$ chromogenic substrate S-2222 (both from Chromogenix, Mölndal, Sweden), $0.63 \mathrm{U} / \mathrm{ml}$ human factor $X$ (Sigma Chemical Co., St. Louis, MO, USA), $0.04 \mathrm{M}$ Tris- $\mathrm{HCl}$ 
$\mathrm{pH} 7.5,0.12 \mathrm{M} \mathrm{NaCl}$ and $8.5 \mathrm{mM} \mathrm{CaCl} 2$. After incubation for another 30 minutes at $37^{\circ} \mathrm{C}$, the reaction was stopped by addition of acetic acid ( $18 \%$ vol./vol.). All samples were assayed with and without factor $X$ in the second stage. Plates were read at $405 \mathrm{~nm}$ on a Titertek Twinreader Plus (Flow Laboratories, Lugano, Switzerland), and optical densities obtained by incubation without factor $X$ were subtracted from the values obtained by incubation with factor $X$, to eliminate the optical density caused by carry-over of factor $X a$ from the first stage. Samples were compared with a standard curve of reference plasma, and results were expressed in percentage. The assay was specific for TFPI, since recombinant TFPI (kindly provided by Dr. Ole Nordfang, Novo Nordisk, Gentofte, Denmark) gave parallel curves to pooled normal plasma, and addition of $5 \mu \mathrm{g} / \mathrm{ml}$ of a polyclonal antibody, raised in rabbits immunized with recombinant TFPI ${ }_{1-161}$ (also a kind gift from Dr. Ole Nordfang) and purified by affinity chromatography, quenched more than $90 \%$ of the inhibition of tissue factor factor VIla. The between assay coefficient of variation was $5 \%$ for normallevels of TFPI (pre-heparin levels; $n=10$ ) and $6 \%$ for high levels of TFPI (post-heparin levels; $n=12$ ).

\section{TFPl antigen assay}

TFPI antigen levels were measured at two different dilutions $(1 / 10,1 / 20$ for pre-heparin and 1/70,1/140 for post-heparin samples) with a commercial enzyme-linked immunosorbent assay (ImmuBind TFPI ELISA Kit; American Diagnostica Inc., Greenwich, CT, USA). To compare antigen with activity levels, antigen assays were not performed with the standard curve of recombinant TFPI provided by the kit, but with a standard curve of reference plasma, and results were expressed in percentage.

\section{Anti-Xa activity assay}

Plasma heparin levels were measured with a chromogenic anti-Xa assay based on the method described by Teien et $a l,{ }^{16}$ modified for microtiter plates. Dilutions of heparin (Liquemin Roche, Milan, Italy) were prepared in $0.9 \%(\mathrm{w} . / \mathrm{v}$.$) saline$ and were further diluted $(1 / 10)$ in pooled normal plasma to obtain a standard curve of $0,0.05,0.1,0.2$ and $0.3 \mathrm{IU} / \mathrm{ml}$. Post-heparin plasma samples were assayed at two appropriate dilutions in pooled normal plasma. Standard curve and samples were further diluted $1 / 5$ in $0.05 \mathrm{M} \mathrm{Tris}-\mathrm{HCl} \mathrm{pH} 8.4,0.175 \mathrm{M} \mathrm{NaCl}$, $7.5 \mathrm{mM} \mathrm{Na} 2 \mathrm{EDTA}$, and $50 \mu$ of these dilutions were allowed to warm to $37^{\circ} \mathrm{C}$ in a microtiter plate. Twenty five $\mu$ l of human activated factor $X$ (Diagnostica Stago, Asnières, France), diluted $1 / 3$, were added to the wells and timing was

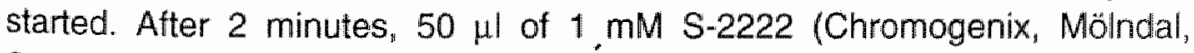
Sweden) was added, and after 6 minutes of incubation at $37^{\circ} \mathrm{C}$ the reaction was stopped with $75 \mu \mathrm{l} 50 \%$ acetic acid. Plates were read against a blank 
without activated factor $\mathrm{X}$ at $405 \mathrm{nM}$ on a Titertek Twinreader Plus (Flow Laboratories, Lugano, Switzerland), and results were expressed in anti-Xa units $/ \mathrm{ml}$.

\section{Statistical analysis}

Results were analysed using the StatView (BrainPower Inc, Calabasas, CA, USA) and the SPSS (SPSS Inc, Chicago, IL, USA) software packages. Type I error was defined for $\alpha=0.05$ in all tests used. Descriptive statistical analysis and the Kolmogorov-Smirnov goodness of fit test showed a sufficient fit of the data to the normal distribution to validate parametric statistical analysis. Between-group differences were analysed with Student's two-tailed t-test for unpaired data.

\section{Results}

In the four normal individuals studied to assess the time course of TFPI response to heparin, the maximum release of TFPI was at 10 minutes after the intravenous injection of $7500 \mathrm{IU}$ of unfractionated heparin (Fig. 14). Heparin concentrations in the post-injection samples, measured as anti-Xa activity, also reached peak values at 10 minutes, and TFPI levels were positively related to heparin levels in plasma samples (Fig. 14). On the basis of these results, we chose a time interval of 10 minutes between heparin injection and post-heparin

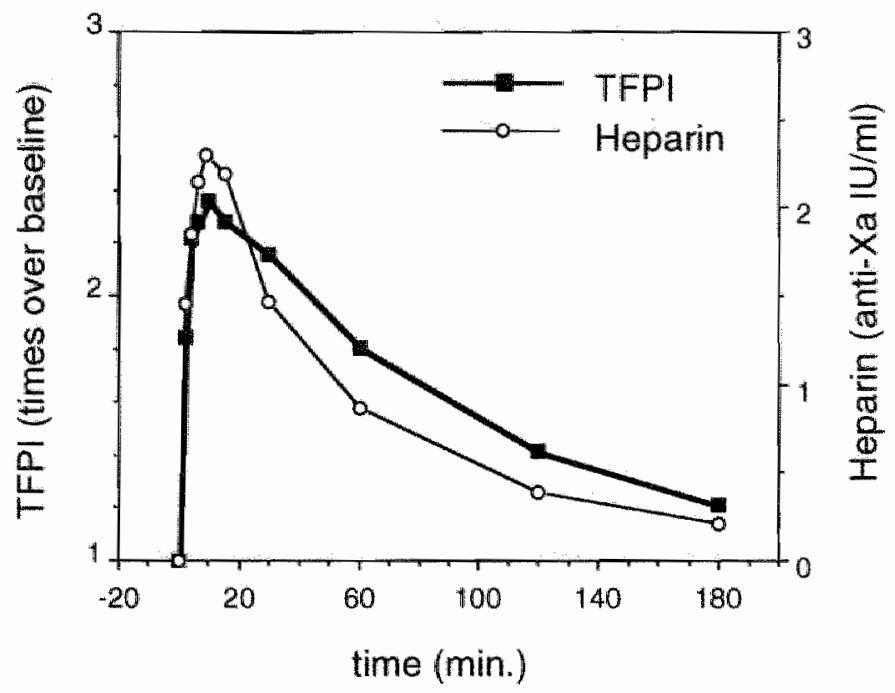

Figure 14. Timecourse of the release of TFPI following the intravenous injection of $7500 \mathrm{lU}$ of heparin at time $0 \mathrm{~min}$. Both data sets are means of the values obtained in 4 normal individuals ( 2 male and 2 female). 


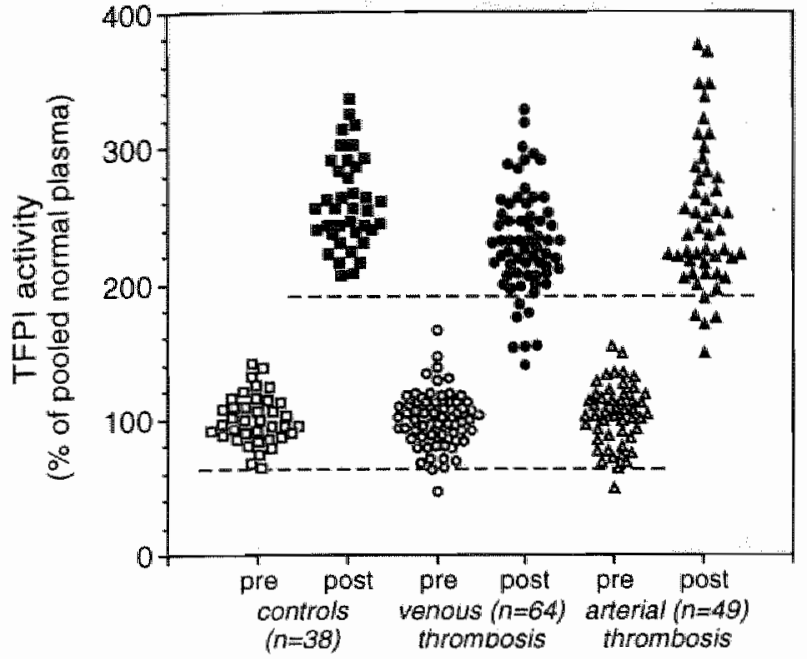

Figure 15. TFPl activity levels before (pre) and 10 min. after (post) heparin injection in 38 normal individuals, 64 patients with juvenile venous thrombosis, and 49 patients with juvenle arterial thrombosis. Dashed lines indicate lower timits of the normal liange for pre- and post-heparin TFPl levels (mean - 2SD of the controls).

sample to study heparin-releasable TFPI in patients and normal individuals.

The mean pre-heparin TFPI activity level in the group of 64 patients with juvenile venous thrombosis $(100 \% \pm 21)$ or 49 patients with juvenile arterial thrombosis $(102 \% \pm 23)$ was not statistically different from that in the control group of 38 normal individuals $(100 \% \pm 18)$ (Fig. 15). Also the mean post-heparin TFPI activity level in patients with arterial thrombosis $(247 \% \pm 53)$ was not different from that in normal individuals $(260 \% \pm 34)$. However, the mean post-heparin TFPI activity level in the group of patients with venous thrombosis was significantly lower than that in the control group (mean \pm SD: $230 \% \pm 39$ vs $260 \% \pm$ 34, $p=0.0002$ ) (Fig. 15).

Considering the mean - 2 SD of TFPI activity levels in the control group as the lower limit of normal range (post-heparin:192\%; pre-heparin: $64 \%$ ), twelve patients had low post-heparin TFPI activity levels, seven with juvenile venous thrombosis and five with juvenile arterial thrombosis (Fig. 15, Table 2). Of these twelve patients, two patients also had low pre-heparin TFPI activity levels. To ascertain that the lower post-heparin TFPI levels were not due to insufficient heparin levels, we measured post-injection anti-Xa levels in all normal individuals enroled for the control group and the patients. The twelve patients with low post-heparin TFPI had post-injection anti-Xa levels comparable to those found in normal individuals ( $2.1 \pm 0.5$ anti-Xa IU/ml) (Table 2).

TFPI antigen levels were measured in the pre- and post-heparin samples of the controls, 17 patients with venous thrombosis and 16 patients with arterial thrombosis, including the twelve patients with low post-heparin TFPI activity levels (Fig. 16). In normal individuals, mean pre-heparin TFPI antigen levels 
were $107 \% \pm 20$, and mean post-heparin TFPI antigen levels were $766 \% \pm$ 133. The low post-heparin TFPI levels found with the activity assay were confirmed by the antigen assay in six of the seven patients with venous thrombosis (Fig. 16, Table 2). In the five patients with arterial thrombosis, low post-heparin TFPI levels were confirmed by the antigen assay in two, with borderline significance (Fig. 16, Table 2). Seven of the twelve patients with low post-heparin

Table 2. Characteristics of patients with low post-heparin TFPI levels

\begin{tabular}{|c|c|c|c|c|c|c|c|c|}
\hline \multirow[b]{2}{*}{ patient } & \multirow[b]{2}{*}{ age } & \multirow{2}{*}{$\begin{array}{l}\text { at first } \\
\text { episode }\end{array}$} & \multicolumn{2}{|c|}{ TFPI activity' } & \multicolumn{2}{|c|}{ TFPI antigen } & \multirow[b]{2}{*}{ heparin $^{2}$} & \multirow{2}{*}{$\begin{array}{l}\text { thrombotic } \\
\text { episodes }\end{array}$} \\
\hline & & & pre & post & pre & post & & \\
\hline \multirow[t]{2}{*}{1} & 22 & 18 & 46 & 140 & 54 & 502 & 1.8 & DVT \\
\hline & & & 55 & 161 & 53 & 463 & 1.7 & \\
\hline \multirow[t]{2}{*}{2} & 35 & 33 & 67 & 152 & 36 & 245 & 1.6 & DVT \\
\hline & & & 55 & 113 & 42 & 300 & 2.5 & \\
\hline 3 & 26 & 20 & 80 & 155 & 60 & 335 & 2.1 & STP, PE \\
\hline 4 & 52 & 24 & 101 & 175 & 101 & 454 & 2.9 & DVT \\
\hline \multirow[t]{2}{*}{5} & 30 & 28 & 81 & 179 & 55 & 480 & 1.8 & DIC \\
\hline & & & 78 & 200 & 60 & 500 & 2.3 & \\
\hline \multirow[t]{3}{*}{6} & 26 & 24 & 67 & 156 & 49 & 398 & 1.9 & CVT \\
\hline & & & 117 & 198 & 77 & 427 & 2.2 & \\
\hline & & & 83 & 183 & 64 & 405 & 1.7 & \\
\hline \multirow[t]{2}{*}{7} & 58 & 41 & 71 & 185 & 89 & 461 & 2.8 & DVT, PE, \\
\hline & & & 77 & 168 & 94 & 545 & 2.1 & STP \\
\hline 8 & 48 & 36 & 92 & 148 & 102 & 582 & 2.5 & PAT, AMI TIA \\
\hline 9 & 20 & 19 & 98 & 168 & 101 & 483 & 2.6 & RAT \\
\hline \multirow[t]{3}{*}{10} & 24 & 11 & 48 & 174 & 58 & 518 & 3.3 & IS \\
\hline & & & 56 & 162 & 47 & 538 & 1.8 & \\
\hline & & & 55 & 133 & 47 & 482 & 2.6 & \\
\hline \multirow[t]{2}{*}{11} & 54 & 43 & 86 & 175 & 60 & 478 & 1.9 & IS \\
\hline & & & 84 & 210 & 61 & 503 & 2.1 & \\
\hline \multirow[t]{2}{*}{12} & 35 & 33 & 101 & 188 & 127 & 529 & 2.9 & TIA, RAT \\
\hline & & & 91 & 182 & 103 & 461 & 2.2 & \\
\hline \multirow{2}{*}{\multicolumn{2}{|c|}{ Nomel range }} & & 64 & $192-$ & $67-$ & 500 & $1.1=$ & \\
\hline & & & 136 & 328 & 147 & 1032 & 3.1 & \\
\hline
\end{tabular}

Values on the second and third lines are those of repeated TFPII release tests.

'TFPI activity and antigen level are both expressed in percentage of pooled normal plasma

Theparin levels are expressed in anti-Xa IU/ml

${ }^{3} \mathrm{DVT}=$ deep vein thrombosis; $\mathrm{STP}=$ superficial thrombophlebitis; $\mathrm{PE}=$ pulmonary embolism; CVT $=$ cerebral wenous thrombosis; $\mathrm{DIC}=$ dessiminated intravascular coagulation; PAT $=$ peripheral arterial thrombosis; $\mathrm{AMI}=$ acute myocardial infarction; $\mathrm{TIA}=$ transient ischemic attack; $\mathrm{RAT}=$ retinal arterial thrombosis; $1 S=$ ischemic stroke 


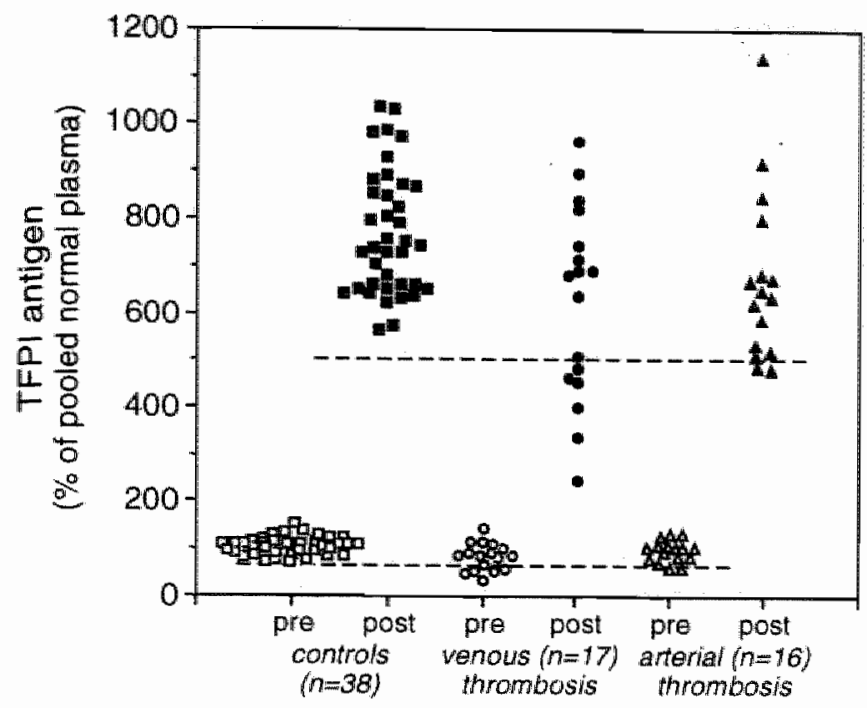

Figure 16. TFPl antigen levels betore (pre) and 10 min. after (post) heparin injection in 38 nomal individuals, 17 patients with juvenile venous thrombosis, and 16 patients with juvenile arterial thrombosis. Included are the 12 patients with thrombosis and low post theparin TFPI activity levels (Fig. 15, Table 2), and 21 patients with throm. bosis and normal postheparin TFPI activity lev. vels. Dashed lines indicate lower limits of the normal range for preand post-heparin TFPI levels (mean - 2SD of the controls).

TFPI levels also had low pre-heparin TFPI antigen levels (Table 2).

The TFPI release test was repeated twice, after at least three months, in six patients, and three times in two (Table 2). Except for patients number 5 and 11, post-heparin TFPI levels were repeatedly found to be below the normal range. Pre- and post-heparin TFPI levels were subsequently measured in family members of ten patients with low post-heparin TFPI levels (Fig. 17). None of the family members studied had experienced episodes of venous or arterial thrombosis. In six of the families studied (numbers 1, 2, 7, 10, 11 and 12), at least one of the first degree relatives also had low levels of post-heparin TFPI (Fig. 17). In three families (numbers 4,6 and 8 ) the results were not informative. Only in one family (number 5), both parents of the propositus had normal levels of heparin-releasable TFPI (Fig. 17).

\section{Discussion}

There is very little previous information on levels of heparin-releasable TFPI in patients with thrombosis. Holst et al found no deficiencies of post-heparin TFPl in a group of 14 elderly patients (mean age $67 \pm 16$ years) with deep vein thrombosis. ${ }^{17}$ However, TFPI was not measured at the time of the peak of the release, but 60 minutes after varied and complex modalities of heparin administration (intravenous injection, followed by either subcutaneous injections or continuous infusion). Furthermore, the study did not include a control group of normal individuals. More recently, Llobet et a/described low TFPI plasma levels 

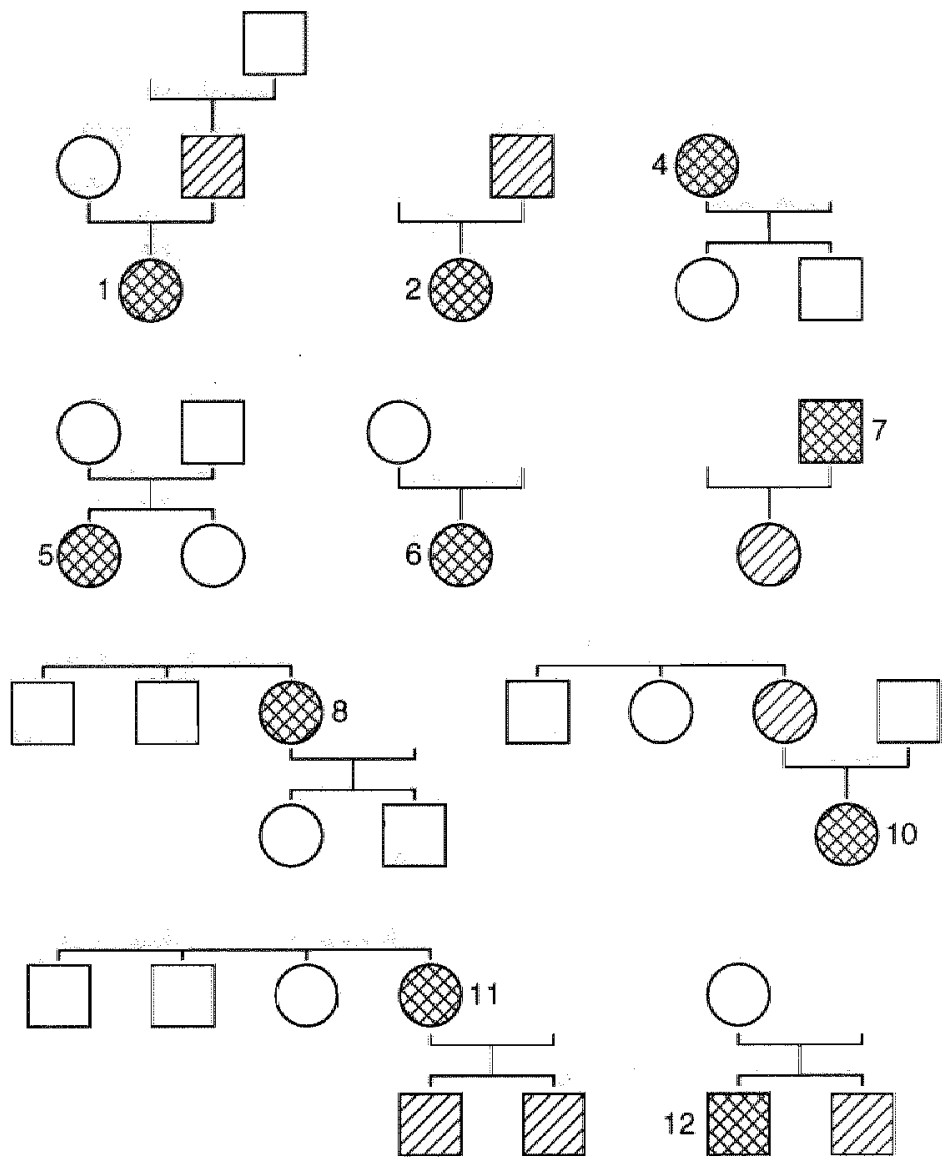

Figure 17. Family studies of low post-heparin TFPI levels. Circles indicate women and squares men. Open symbols indicate nombal TFPI levels hatched symbols low post-heparin TFPI levels and double hatched symbols low post-heparin TFPI levels together with thrombasis. The numbers refer to the patients in Table 2.

in two sibblings of a thrombophilic family. ${ }^{18}$ They also found low TFPI levels after intravenous injection of heparin, but no control group for post-heparin TFPI levels was included.

In this study, 12 patients with juvenile thrombosis had low levels of heparinreleasable TFPI. In almost all patients, these low levels were repeatedly confirmed after a few months, indicating that the defect was not transient. Six famillies with low post-heparin TFPl levels in at least one first degree relative of the index patients were found, which suggests that decreased heparin-releasable TFPI may be inheritable. Only in one family, genetic transmittance of the defect did not appear to be present. The propositus of this family, however, was 
one of the two patients who did not show the defect when the release test was performed for the second time. Since the levels measured were as low as half the values in normal individuals, these results suggest that several families with heterozygous TFPI deficiency were found, and that TFPI deficiency might be a possible cause of thrombophilia. However, since none of the deficient familly members studied had experienced episodes of thrombosis, co-segregation of low post-heparin TFPI with inherited thrombosis could not be demonstrated.

The antigen assay confirmed the low levels of post-heparin TFPI as measured by activity assay in six out of the seven patients with venous thrombosis. In patients with arterial thrombosis and low post-heparin TFPI activity, antigen levels were less markedly low, only just below the normal range, and confirmed the results obtained with the activity assay only in two of five patients. These results suggest that low post-heparin TFPI levels may be associated more with venous thrombosis than with arterial thrombosis. In conclusion, several patients with juvenile thrombosis and low post-heparin TFPI levels were found. The defect was not transient, and was present in at least one relative of six patients. These results suggest that low heparin-releasable TFPI might be inheritable. The possible causative role of this defect in the pathogenesis of thrombophilia remains uncertain, since we could not demonstrate co-segregation of low heparin-releasable TFPI with thrombotic manifestations in six families studied.

\section{References}

Rao LVM, Rapaport SI. Studies of a mechanism inhibiting the initiation of the extrinsic pathway of coagulation. Blood 1987; 69: 645-651

2 Broze GJ Jr, Miletich JP. Characterization of the inthibition of tissue factor in serum. Blood 1987; 69: 150-155

3 Lindahl AK, Sandset PM, Abildgaard U. The present status of tissue factor pathway inhibitor. Blood Coag Fibrinol 1992; 3: 439-449

4 Broze GJ Jr, Warren LA, Novotny WF, Higuchi DA, Girard JJ, Miletich JP. The lipoprotein-associated coagulation inhibitor that inhibits the factor VIl-tissue factor complex also inhibits factor $\mathrm{Xa}$ : insight into its possible mechanism of action. Blood 1988; 71: 335-343

5 Warn-Cramer BJ, Rao LVM, Maki SL, Rapaport SI. Modifications of extrinsic pathway inhibitor (EPI) and factor Xa that affect their ability to interact and to inhibit factor VIla/tissue factor: evidence for a two-step model of inhibition. Thromb Haemost 1988; 60: 453-456

6 Sandset PM, Abildgaard U, Larsen ML. Heparin induces release of extrinsic coagulation pathway inhibitor (EPI). Thromb Res 1988; 50: 803-813 
7 Hubbard AR, Jennings CA. Inhibition of the tissue factor-factor VIl complex: involvement of factor Xa and lipoproteins. Thromb Res 1987; 46: 527-537

8 Novotny WF, Girard TJ, Miletich JP, Broze GJ Jr. Platelets secrete a coagulation inhibitor functionally and antigenically similar to the lipoprotein associated coagulation inhibitor. Blood 1988; 72: 2020-2025

9 Wun TC, Kretzmer KK, Girard TJ, Miletich JP, Broze GJ Jr. Cloning and characterization of a CDNA coding for the lipoprotein-associated coagulation inhibitor shows that it consists of three tandem Kunitz-type inhibitory domains. J Biol Chem 1988; 263: 6001-6004

10 Ariëns RAS, Faiioni EM, Mannucci PM. Repeated released of the tissue factor pathway inhibitor. Thromb Haemost 1994; 72: 327-328

11 Anderson S, Cohen AT, Melissari E, Scully MS, Kakkar VV. Loss of heparin-releasable tissue factor pathway inhibitor in patients undergoing PTCA. Thromb Haemost 1995; 73: 328-329

12 Hansen JB, Sandset PM, Huseby KR, Huseby NE, Nordøy A. Depletion of intravascular pools of tissue factor pathway inhibitor (TFPI) during repeated or continuous intravenous infusion of heparin in man. Thromb Haemost 1996; 76: 703-709

13 Nemerson $Y$. The tissue factor pathway of blood coagulation. Semin Hematol 1992; $29: 170-176$

14 Novotny WF, Brown SG, Miletich JP, Rader DJ, Broze GJ Jr. Plasma antigen levels of the lipoprotein-associated coagulation inhibitor in patient samples. Blood 1991; 78: 387-393

15 Goodwin CA, Melissari E, Kakkar VV., Scully MF. Plasma levels of tissue factor pathway inhibitor in thrombophilic patients. Thromb Res 1993; 72 : 363-366

16 Teien AN, Lie M, Abildgaard U. Assay of heparin in plasma using a chromogenic substrate for activated factor X. Thromb Res 1976; 8: 413-416

17 Holst J, Lindblad B, Wedeberg E, Bergqvist D, Nordfang O, Østergaard PB, Hedner U. Tissue factor pathway inhibitor (TFPI) and its response to heparin in patients with spontaneous deep vein thrombosis. Thromb Res 1993; 72: 467-470

18 Llobet D, Falkon L, Mateo J, Vallve C, Martinez E, Fontcuberta J, Borrell M. Low levels of tissue factor pathway inhibitor (TFPI) in two out of three members of a family with thrombophilia. Thromb Res 1995; 80: 413-422 


\section{Chapter 5}

Increased thrombin and plasmin generation together with high plasma levels of activated factor VII in patients with the nephrotic syndrome

Ariëns RAS, Coppola $R$, Bottasso $B$, Moia $M$, Rivolta $R$, Ponticelli $C$, Mannucci $P M$. Submitted for publication 


\section{Abstract}

A hypercoagulable state in patients with nephrotic syndrome has been hypothesized, based on frequent thromboembolic complications and thrombogenic alterations of the hemostatic system such as increased levels of coagulation zymogens and decreased anticoagulant proteins. The aim of this study was to re-evaluate this hypercoagulable state with novel and sensitive assays that measure coagulation and fibrinolysis activation. Plasma levels of activated factor VII (FVIia), prothrombin fragment $1+2(F 1+2)$, thrombin - antithrombin complexes (TAT) and plasmin - antiplasmin complexes (PAP) were measured in 31 patients with nephrotic syndrome (proteinuria $7.7 \pm 5.6 \mathrm{~g} / 24 \mathrm{~h}$ ), compared with a group of 62 age- and sex-matched controls. Significantly $(p<0.0001$ for all) higher levels of FVlla ( $4.7 \pm 2.0$ vs $3.1 \pm 1.0 \mathrm{ng} / \mathrm{ml}), \mathrm{F} 1+2$ (1.9 $\pm 0.6 \mathrm{vs} 1.1$ $\pm 0.3 \mathrm{nM})$ and TAT $(8.7 \pm 6.4 \mathrm{vs} 2.4 \pm 1.1 \mathrm{ng} / \mathrm{ml})$ were found in the patients. There was a positive correlation between FVIla and $F 1+2(r=0.60, p=0.0004)$. Plasma levels of PAP were also increased $(0.69 \pm 0.36$ vs $0.35 \pm 0.12 \mu \mathrm{g} / \mathrm{ml}$, $p<0.0001)$. Of 31 patients, $30(97 \%)$ had at least one of the activation markers above the upper limit of the normal range. It is concluded that the nephrotic state is associated with a marked activation of the tissue factor coagulation pathway, but a concomitant activation of the fibrinolytic system is also present.

\section{Introduction}

Thromboembolism is one of the most severe complications in patients with the nephrotic syndrome. ${ }^{1.2}$ The frequency of thromboembolic complications, of which pulmonary embolism and deep vein thrombosis are the most serious, has been estimated between $20 \%$ and $55 \%$, among the highest encountered in medicine. ${ }^{1.4}$ Renal vein thrombosis is also a frequent complication, which mainly occurs in patients with membranous nephropathy with an incidence of 3.8 episodes every $100 /$ patient/months. ${ }^{3}$ Several potentially thrombogenic abnormalities of the hemostatic system have been found in the nephrotic syndrome. Thrombocytosis and in vitro platelet hyperaggregability (but not under flow conditions in a perfusion chamber $)^{5}$ are frequently present. ${ }^{6.7}$ Increased plasma levels of fibrinogen, cofactors $\mathrm{V}$ and VIII, von Willebrand factor and factor VII have also been found. ${ }^{5,0,8}$ Furthermore, several studies have found defective fibrinolysis, expressed by deficiency of plasminogen, ${ }^{9}$ and increased levels of $\alpha 2$-antiplasmin. ${ }^{10}$ Finally. acquired deficiencies of naturally occuring anticoagulant proteins (antithrombin and protein S), due to loss in the urine, have been reported. ${ }^{15-15}$

These hemostatic abnormalities determine a hypercoagulable state which may cause the thromboembolic complications. Nowadays, accurate evalu- 
ations of hypercoagulable states are possible using sensitive assays that measure the degree of enzymatic activation of clotting zymogens. The degree of thrombin generation can be assessed by measuring plasma levels of prothrombin fragment $1+2(F 1+2)$, which is cleaved from prothrombin upon proteolysis by activated factor $X$, and by measuring plasma levels of the complex of the enzyme and its inhibitor (thrombin - antithrombin complexes, TAT). ${ }^{16}$ Plasma levels of plasmin - antiplasmin complexes (PAP) are a measure of plasmin generation, and therefore of activation of the fibrinolytic system." Activation of the main physiologic trigger of coagulation can be quantified by plasma levels of activated factor VII (FVIII). When blood contacts tissue factor, complex formation between factor VII and tissue factor leads to the activation of factor VII. The tissue factor / FVIlla complex then activates factors IX and X with subsequent thrombin generation. Plasma levels of FVIIa are therefore proportional to the extent of tissue factor exposure and coagulation activation. With recombinant engineering a truncated, soluble tissue factor has been made, that has a normal cofactor function but does not promote activation of factor VII. ${ }^{18}$ A prothrombin time-based assay with this truncated form as trigger instead of full-length tissue factor is specific for FVIla, as described by Morrisey et al. ${ }^{19}$

Up to date, studies of sensitive markers of coagulation activation in nephrotic patients are scarce in the literature. A few studies have reported high plasma levels of fibrinopeptide $A$, an index of fibrin deposition. ${ }^{20-22}$ Only one study has measured plasma levels of $F y+2$ and TAT, which were high in 21 patients. ${ }^{22}$ Plasma levels of FVIla and PAP have not yet been determined. The aim of the present study was to evaluate the degree of activation of the tissue factor coagulation pathway and fibrinolysis in nephrotic patients, using novel markers such as plasma FVIla and PAP levels.

\section{Patients and Methods}

\section{Patients}

Thirty-one patients with nephrotic proteinuria, 11 men and 20 women, age $47 \pm 19$ (mean \pm SD), were included in the study. The lower limit of proteinuria to confirm the diagnosis of nephrotic syndrome was $3.0 \mathrm{~g} / 24$ hours. The patient population of this study had proteinuria levels of $7.7 \pm 5.6$ (mean \pm SD) $g / 24$ hours, serum albumin $3.2 \pm 0.6 \mathrm{~g} / \mathrm{dl}$, creatinine clearance $61 \pm 34 \mathrm{ml} / \mathrm{min}$, cholesterol $313 \pm 124$ $\mathrm{mg} / \mathrm{dl}$, and triglycerides $219 \pm 127 \mathrm{mg} / \mathrm{dl}$. Underlying renal diseases included membranous glomerulopathy in $12(39 \%)$, diffuse lupus nephritis in $8(26 \%)$, focal and segmental glomerulosclerosis in $4(13 \%)$, cryoglobulinemic nephritis in $2(7 \%)$, minimal change glomerulonephritis in $1(3 \%)$, amyloidosis in $1(3 \%)$, 
mesangio-capillary glomerulonephritis in $1(3 \%), \lg$ A nephropathy in $1(3 \%)$ and nephropathy of unknown origin in $1(3 \%)$. Patients with congenital coagulation disorders, liver disease, malnutrition and those taking drugs known to affect coagulation or fibrinolysis were excluded from the study. Informed consent to give biood samples was obtained from all patients.

\section{Control group}

Sixty-two age-and sex-matched normal subjects ( 22 men and 40 women, age 48 \pm 18 ) were enroled in the study. The volunteers were recruited from the hospital staff, donors visiting the blood bank, and older people in a senior residence. All subjects were apparently healthy, ambulatory and self-sufficient, and none had clinical or laboratory evidence of coagulation, liver, kidney or other disorders.

\section{Blood sampling and processing}

Venous blood was collected in siliconized Vacutainer tubes (Beckton Dickinson, Milan, Italy) containing $0.13 \mathrm{M}$ trisodium citrate, nine parts of blood to one part of trisodium citrate. Within 1 hour after collection, the samples were centrifuged at $2000 \mathrm{~g}$ for 15 minutes at room temperature to obtain platelet-poor plasma, frozen in aliquot parts in liquid nitrogen, and stored at $-80^{\circ} \mathrm{C}$ until analysis.

\section{Assays}

FVlla was quantified with a one-stage clotting assay using recombinant, truncated (soluble) tissue factor $\left(\mathrm{TF}_{1-218}\right.$ ), which does not promote significant activation of zymogen factor VII and reacts mainly with the enzyme. ${ }^{19}$ The assay was performed on an ACL-300R automated coagulometer from Instrumentation Laboratories (Ascoli Piceno, ltaly). Samples were compared with a standard curve of recombinant activated factor VII (Novo Nordisk, Gentofte, Denmark), and results were expressed in $\mathrm{ng} / \mathrm{ml}$. F1+2, TAT and PAP were measured with commercial ELISA kits (Enzygnost $F 1+2$ micro, Enzygnost TAT micro, and EIA PAP micro; Istituto Behring S.p.A., Scoppito, Italy).

\section{Statistical analysis}

Data were elaborated with linear regression analysis and Student's unpaired two-tail t-test, using the StatView (BrainPower Inc., Calabasas, CA, USA) software package. Type I error was defined for $\alpha=0.05$ in all tests performed.

\section{Results}

Plasma levels of FVIla, a marker of tissue factor exposure and coagulation activation, were significantly higher in the group of 31 patients than in the group 
of 62 age- and sex-matched controls (mean \pm SD: $4.7 \pm 2.0 \mathrm{vs} 3.1 \pm 1.0 \mathrm{ng} / \mathrm{ml}$, $p<0.0001$ ), even though they were within the normal range in several patients (Fig. 18, panel A). Linear regression analysis showed that there was no significant correlation between plasma levels of FVlla and the level of proteinuria or serum albumin (data not shown).
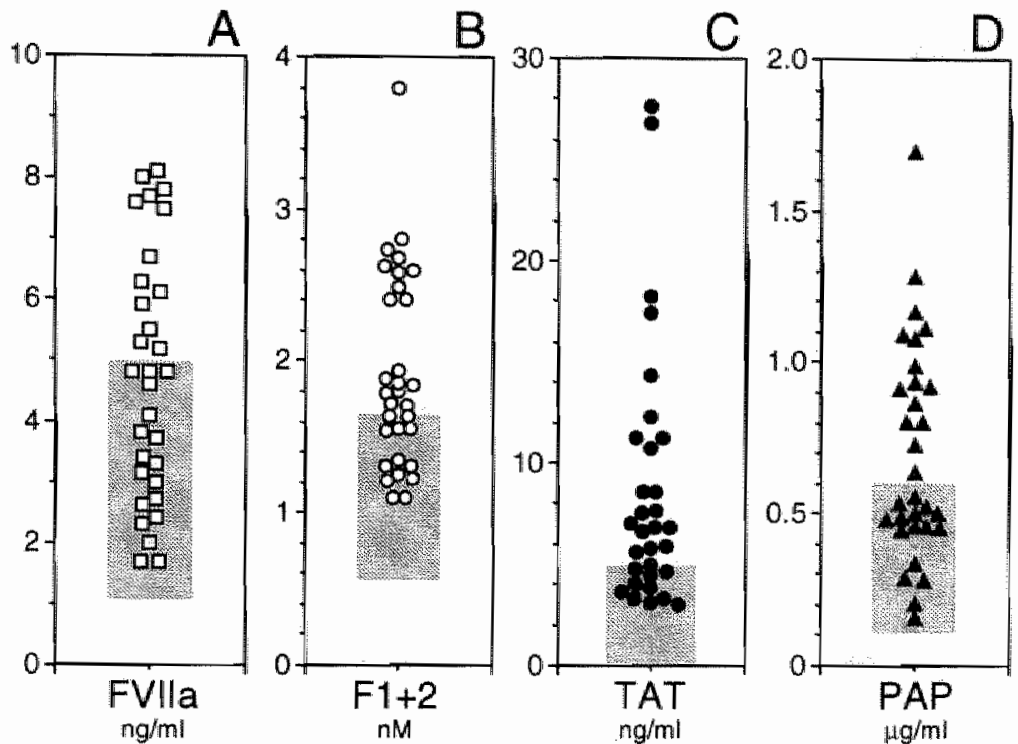

Figure 18. Plasma leveis of FVIla (panel A), F1+2 (panel B), TAT (panel C), and PAP (panel D) in 31 patients with the nephrotic syndrome. The shaded area represents the normal range of each variable, calculated from two standard deviations around the mean plasma levels in 62 ageand sex-matched controls.

Plasma levels of $F 1+2$, a marker of thrombin generation, were significantly higher in the group of nephrotic patients than in the control group (1.9 0.6 vs 1.1 $\pm 0.3 \mathrm{nM}, p<0.0001$; Fig. 18 , panel $B$ ). Also plasma levels of TAT were significantly increased ( $8.7 \pm 6.4 \mathrm{vs} 2.4 \pm 1.1 \mathrm{ng} / \mathrm{ml}, p<0.0001$; Fig. 18 , panel C). Finally, plasma levels of $P A P$, a marker of plasmin generation, were significantly higher in the patient group than in the control group $10.69 \pm 0.36$ vs $0.35 \pm 0.12 \mathrm{~g} / \mathrm{ml}$, $p<0.0001 ; \mathrm{Fig}$. 18 , panel D). As for FVlla, neither F1+2, TAT nor PAP were correlated significantly with the level of proteinuria or plasma albumin (data not shown).

Levels of FVIla were significantly correlated with $F 1+2(r=0.60, p=0.0004$; Fig. 19), but not with TAT. There was a relatively weak correlation between $\mathrm{F} 1+2$ and TAT $(r=0.43, p=0.016)$. Plasma levels of PAP were correlated with $F 1+2(r$ $=0.54, p=0.0017)$ and with FVla $(r=0.55, p=0.0013)$. Thirty out of 31 patients $(97 \%)$ had plasma levels of at least one of the activation markers higher than the upper limit of the normal range (mean $\pm 2 S D$ in 62 controls). Only one male patient 
of 57 years with membranous glomerulopathy and proteinuria of $5.0 \mathrm{~g} / 24$ hours had normal plasma levels of FVIla $(2.3 \mathrm{ng} / \mathrm{ml}), \mathrm{F} 1+2(1.35 \mathrm{nM}), \mathrm{TAT}(3 . \mathrm{ng} / \mathrm{ml})$ and PAP $(0.20 \mu \mathrm{g} / \mathrm{ml})$.

\section{Discussion}

Augmented plasma levels of factor VIl zymogen have been previously reported in patients with the nephrotic syndrome. ${ }^{6.8}$ Furthermore, increased procoagulant activity due to tissue factor has been found in isolated glomeruli both from rats with mercuric chloride induced nonproliferative nephritis and from patients with crescentic glomerulonephritis. ${ }^{23,24}$ In this study, we show that in patients with nephrotic proteinuria caused by different types of glomerular diseases there is an increased concentration of the active enzyme of factor VII in vivo. In complex with tissue factor, FVlla is the main trigger of coagulation both in physiological and pathological conditions, and increased plasma levels of FVila have been associated with thromboembotic complications in cancer ${ }^{25}$ In agreement with Chen et al, ${ }^{22}$ we found a significant increase in plasma levels of $\mathrm{F} 1+2$, released from prothrombin upon cleavage by activated factor $X_{i}$ and a marked increase of TAT, the complex of thrombin and its inhibitor. These high levels of $F++2$ and TAT show that heightened thrombin generation is present in nephrotic patients. F1+2 was correlated significantly with FVlla in the group of patients studied, which indicates that the increased thrombin generation is caused by activation of the tissue factor dependent coagulation pathway. However, levels of TAT did not correlate with FVlla. This apparent discrepancy might be due to variations of antithrombin levels. Many studies have found acquired deficiencies of antithrombin in the nephrotic syndrome, ${ }_{1}^{11.13}$ and antithrombin deficiency has been proposed as one of the major causes of hypercoagulability in these patients. ${ }^{1,2}$ Therefore, we speculate that deficiency of antithrombin might cause low levels of TAT in some patients with marked hypercoagulability and high levels of FVIla and $\mathrm{F} 1+2$. In agreement with this hypothesis, we found only a modest correlation between TAT and F1+2, and Chen et al did not find a statistically significant relation between these two markers of coagulation activation. ${ }^{22}$

It has been suggested that the risk for thrombosis and therefore the intensity of hypercoagulability is related to the degree of proteinuria and albuminemia. ${ }^{26}$ in the present study, however, we did not observe a direct correlation between levels of the various molecular markers of coagulation activation and the degree of proteinuria or serum albumin levels. Since we selected patients with proteinuria higher than $3.0 \mathrm{~g} / 24$ hours, it might be that maximal hypercoagulability is reached only with severe proteinuria. This is supported by the finding that 30 


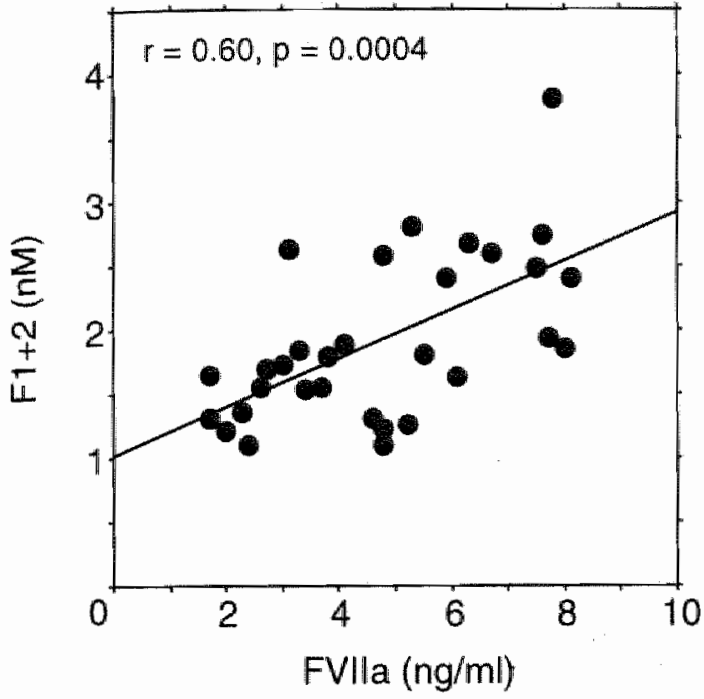

Figure. 19. The relation between FVlla and $F 1+2$ in 31 patients with the nephrotic syndrome; the correlation coefficient and statistical signficance were obtained by linear regression analysis.

out of 31 patients had at least one of the activation markers above the normal range. However, one has to bear in mind that, besides hypercoagulability, other mechanisms such as increased platelet aggregability may play a role in the pathogenesis of thromboembolic complications in patients with the nephrotic syndrome. ${ }^{7}$

Previous studies have put forward arguments for reduced fibrinolytic potential in proteinuric patients, based on deficiency of plasminogen and increased leveis of antiplasmin. ${ }^{9,10}$ More recent studies have reported high plasma levels of D-dimer, showing that increased degradation of fibrin is present in nephrotic patients. ${ }^{27.28}$ Accordingly, we found high plasma levels of PAP, which demonstrates that the nephrotic syndrome is associated with increased plasminin generation. The levels of PAP showed a significant correlation with $\bar{F} 1+2$ and FVIla. Hence, this phenomenon, found in other conditions associated with high coagulation enzyme activity, ${ }^{29}$ might be the expression of hyperfibrinolysis secondary to increased thrombin generation and activity, expressed by high levels of $\mathrm{F} 1+2$.

In conclusion, we found a marked activation of the tissue factor coagulation pathway and increased thrombin generation in patients with the nephrotic syndrome, expressed by high levels of FVIla and of the more down-stream markers of activation $\mathrm{F} 1+2$ and TAT. This hypercoagulable state in patients with the nephrotic syndrome may underlie an increased risk for venous thrombosis and thromboembolism. Activation of fibrinolysis due to plasmin generation was also present in these patients, and might represent hyperfibrinolysis secondary to increased coagulation activity. 


\section{References}

1 Llach F: Hypercoagulability, renal vein thrombosis, and other thrombotic complications of nephrotic syndrome. Kidney Int 28: 429-439, 1985

2 Rabelink TJ, Zwaginga JJ, Koomans HA, Sixma JJ: Thrombosis and hemostasis in renal disease. Kidney int 46: 287-296, 1994

3 Sarasin FP, Schifferli JA: Prophylactic oral anticoagulation in nephrotic patients with idiopathic membranous nephropathy. Kidney Int 45: 578-585, 1994

4 Bellomo R, Atkins RC: Membranous nephropathy and thromboembolism: is prophylactic anticoagulation warranted? Nephron 63: 249-253, 1993

5 Zwaginga $\mathrm{JJ}$, Koomans HA, Sixma $\mathrm{J}\rfloor$, Rabelink AJ: Thrombus formation and platelet vessel wall interaction in the nephrotic syndrome under flow conditions. J Clin Invest 931: 204-211, 1994

6 Kanfer A, Kleindrecht D, Broyer M, Josso F: Coagulation studies in 45 cases of nephrotic syndrome without uremia. Thromb Diathes Haemorr 24: $562-571,1970$

7 Remuzzi G, Mecca G, Marchesi D, Livio M, De Gaetano G, Donati MB, Siver MJ: Platelet hyperaggregability and the nephrotic syndrome. Thromb Res 16: 345-354, 1979

8 Kendall AG, Lohmann RE, Dossetor JB: Nephrotic syndrome: a hypercoagulable state. Arch Intern Med 127: 1021-1027, 1971

9 Thompson C, Forbes CD, Prentice CR, Kennedy AC: Changes in blood coagulation and fibrinolysis in the nephrotic syndrome. $Q \mathrm{~J}$ Med 43 : 399-407, 1974

10 Du $X H$, Glas-Greenwalt $P$, Kant KS, Allen CM, Hayes S, Pollak VE: Nephrotic syndrome with renal vein thrombosis: Patho-genetic importance of a plasma inhibitor. Clin Nephrol 24: 186-191, 1985

11 Kauffman RH, Veltkamp JJ, van Tilburg NH, van Es LA: Acquired antithrombin III deficiency and thrombosis in the nephrotic syndrome. Am J Med 65: 607-613, 1978

12 Boneu B, Boissou F, Abbal M, Sic P, Caranobe C, Barthe P: Comparison of progressive antithrombin $1 / 1$ activity and concentration of three thrombin inhibitors in nephrotic syndrome. Thromb Haemost 46: 623-625, 1981

13 Vaziri ND, Paule P, Toohey J, Hung $E$, Alikhani S, Drawish R, Pahl M: Acquired deficiency and urinary excretion of antithrombin III in nephrotic syndrome. Arch Int Med 144: 1802-1803, 1984

14 Vigano-D'Angelo S, D'Angelo A, Kaufman CE, Scholer C, Esmon CT, Comp PC: Protein S deficiency occurs in the nephrotic syndrome. Ann Int Med 170: 42-47, 1987 
15 Goualt-Heilmann M, Gadelha-Parente $T$, Levent $M$, Intrator $L$, Rostoker G, Lagrue G: Total and free protein $S$ in nephrotic syndrome. Thromb Res 49: $37-42,1988$

16. Teite! JM, Bauer KA, Lau HK, Rosenberg RD: Studies of the prothrombin activation pathway utilizing radioimmunoassays for the $F 2 / F 1+2$ fragment and thrombin-antithrombin complex. Blood 59: 1086-1097, 1982

17 Holvoet P, de Boer A, Verstreken M, Collen D: An enzyme-linked immunosorbent assay (ELISA) for the measurement of plasmin- $\alpha_{2}$-antiplasmin complex in human plasma - Application to the detection of in vivo activation of the fibrinolytic system. Thromb Haemost 56: 124-127, 1986

18 Neuenschwander PF, Morrisey $\mathrm{JH}$ : Deletion of the membrane anchoring region of tissue factor abolishes autoactivation of factor $\mathrm{V} / \mathrm{l}$ but not cofactor function. J Biol Chem 267: 14477-14482, 1992

19 Morrisey $\mathrm{JH}$, Macik BG, Neuenschwander PF, Comp PC: Quantitation of activated factor VII levels in plasma using a tissue factor mutant selectively deficient in promoting factor VII activation. Blood 81: 734-744, 1993

20 Tomura S, Oono $\mathrm{Y}$, Kuriyama $\mathrm{R}$, Takeuchi J: Plasma concentrations of fibrinopeptide $A$ and fibrinopeptide $B \beta 15-42$ in glomerulonephritis and the nephrotic syndrome. Arch Intern Med 145: 1033-1035, 1985

21 Sagripanti A, Cupisti A, Ferdeghini M, Pinori E, Barsotti G: Molecular markers of hemostasis activation in nephrotic syndrome. Nephron 51: 25-28, 1989

22 Chen TY, Huang CC, Tsao CJ: Hemostatic molecular markers in nephrotic syndrome. Am I Hematol 44: 276-279, 1993

23 Kanfer $A$, de Prost D, Guettier $C$, Nochy D, Le Floch $V$, Hinglais N, Druet P: Enhanced glomerular procoagulant activity and fibrin deposition in rats with mercuric chloride-induced autoimmune nephritis. Lab Invest 57: 138-143, 1987

24 Tipping PG, Dowling JP, Holdsworth SR: Glomerular procoagulant activity in human proliferative glomerulonephritis. J Clin Invest 81: 119-125, 1988

25 Kakkar AK, DeRuvo N, Chinswangwatanakul V, Tebbutt S, Williamson RCN: Extrinsic-pathway activation in cancer with high factor VIla and tissue factor. Lancet 346: 1004-1005, 1995

26 Kanfer A: Coagulation factors in nephrotic syndrome. Am J Nephrol 10 (Suppl 1): 63-68, 1990

27 Vaziri ND, Gonzales EC, Shayestehfar B, Barton CH: Plasma levels and urinary excretion of fibrinolytic and protease inhibitory proteins in nephrotic syndrome. J Lab Clin Med 124: 118-124, 1994

28 Sagripanti A, Cupisti A, Baicchi U, Ferdeghini M, Barsotti $G$ : In vivo measurements of fibrin formation and degradation in nephrotic patients. Int J Clin Lab Res 24: 113-116, 1994 
29 Mari D, Mannucci PM, Coppola R, Bottasso B, Bauer KA, Rosenberg RD: Hypercoagulability in centenarians: the paradox of successful aging. Blood 85: 3144-3149, 1995 


\section{Chapter 6}

High levels of tissue factor pathway inhibitor in patients with the nephrotic syndrome

Ariëns RAS, Moia $M$, Rivolta R, Ponticelli $C$, Mannucci PM.

Submitted for publication 


\section{Summary}

Acquired deficiency of naturally occurring anticoagulant proteins, due to loss in the urine, has been proposed as one of the major thrombogenic alterations in nephrotic proteinuria. The aim of this study was to investigate if proteinuria may induce deficiency of tissue factor pathway inhibitor (TFPI). TFPI, protein $C(P C)$ and antithrombin (AT) were measured in 31 patients with nephrotic proteinuria, compared with 62 age- and sex-matched controls. The mean plasma level of TFPI was significantly higher in patients with nephrotic proteinuria than in controls $(162 \pm 43$ vs $104 \pm 19 \%, p<0.0001)$, and none of the patients had TFPI deficiency. Intravenous injection of 7500 IU unfractionated heparin induced a further 1.66 and 1.87 fold increase of TFPI in two patients with high pre-heparin levels. Also the mean plasma level of $P C$ was significantly higher in patients (184 \pm 52 vs $98 \pm 18 \%$, $p<0.0001)$. Mean AT antigen levels were not significantly different between patients and controls, and AT activity was only marginally increased ( $108 \pm 19$ vs $102 \pm 10 \%, p=0.049)$. Three out of 31 patients had AT deficiency (antigen: 66, 73, 75\%; activity: $59,72,81 \%$ ). In conclusion, proteinuria is not associated with TFPI deficiency, but with a marked increase of this anticoagulant protein. The acquired thrombophilic diathesis of patients with nephrotic proteinuria can therefore not be attributed to TFPI deficiency.

\section{Introduction}

Thromboembolism is a relatively frequent and severe complication in patients with the nephrotic syndrome. ${ }^{12}$ The main thrombotic events in these patients are renal vein thrombosis, pulmonary embolism and deep vein thrombosis. Since the nephrotic syndrome is characterized by heavy proteinuria, i.e. the loss of (low molecular-weight) proteins in the urine, acquired deficiency of naturally occurring anticoagulant proteins due to urinary loss has been proposed as one of the major thrombogenic mechanisms in patients with the nephrotic syndrome. Indeed, acquired deficiencies of antithrombin (AT) ${ }^{3.5}$ and free protein $S^{6,7}$ have been described in these patients. Not all natural anticoagulants, however, decrease in the nephrotic syndrome: plasma levels of the thrombin inhibitors $\alpha 2$-macroglobulin ${ }^{4,8}$ and heparin cofactor $1{ }^{9}$ are increased, and leveis of protein $\mathrm{C}(\mathrm{PC})$ are normal ${ }^{10}$ or increased. ${ }^{11113}$

The tissue factor pathway inhibitor (TFPI) ${ }^{4-16}$ is a serine proteinase inhibitor of the kunin superfamily ${ }^{17}$ with a molecular weight of around $40 \mathrm{kDa}$ and a plasma concentration of $2.5 \mathrm{nM}$. TFPI inhibits the main trigger of physiologic hemostasis: it first binds and inhibits activated factor $X$, and then, in the 
presence of calcium, the TFPI / factor $X$ complex binds to and inhibits tissue factor / factor VIII, resulting in a quaternary inhibitory complex. In vivo, the inhibitor is not only found in the circulating blood, but a major fraction of TFPI is probably bound to the endothelial cells of the vessel wall, and can be repeatedly released by injection of heparin. ${ }^{18,19}$ This heparin-releasable TFPI probably contributes significantly to the anticoagulant properties of the vascular endathelium. ${ }^{20}$ Deficiency of TFPI associated with thrombosis has not been found yet, but studies in rabbits have demonstrated that immuno-depletion of TFPI leads to massive intravascular coagulation. ${ }^{21,22}$

The aim of this study was to investigate if proteinuria may lead to acquired deficiency of TFPI, which might contribute to an increased risk of venous thrombosis in patients with the nephrotic syndrome. We measured plasma levels of TFPI activity in 31 patients with nephrotic proteinuria, and compared these levels with those of AT and PC.

\section{Patients and Methods}

\section{Patients}

Thirty-one patients, 11 men and 20 women, age $47 \pm 19$ (mean $\pm S D$ ), with nephrotic proteinuria defined as a daily urine protein excretion of more than 3.0 $\mathrm{g} / 24$ hours (mean $\pm \mathrm{SD}: 7.7 \pm 5.6 \mathrm{~g} / 24$ hours) were included in the study. The mean serum albumin levels were $3.2 \pm 0.6 \mathrm{~g} / \mathrm{dl}$, creatinine clearance $61 \pm 34$ $\mathrm{ml} / \mathrm{min}$, serum cholesterol $313 \pm 124 \mathrm{mg} / \mathrm{dl}$, and serum triglycerides $219 \pm 127$ $\mathrm{mg} / \mathrm{dl}$. Underlying causes of proteinuria included membranous nephropathy in $12(39 \%)$, diffuse lupus nephritis in $8(26 \%)$, focal and segmental glomerulosclerosis in $4(13 \%)$, cryoglobulinemic nephritis in $2(7 \%)$, minimal change glomerulonephritis in $1(3 \%)$, renal amyloidosis in $1(3 \%)$, mesangio-capillary glomerulonephritis in $1(3 \%), \lg A$ nephritis in $1(3 \%)$ and nephropathy of unknown origin in $1(3 \%)$. Patients with congenital coagulation disorders, liver disease, malnutrition and those taking drugs known to affect coagulation or fibrinolysis were excluded from the study. Informed consent for blood sampling was obtained from all patients. Informed consent for intravenous injection of heparin, used to study the vessel wall-bound pool of TFPI, was obtained from two male patients.

\section{Control group}

Sixty-two age- and sex-matched normal subjects ( 22 men and 40 women, age $48 \pm 18$ ) were enroled in the study. The volunteers were recruited from the hospital staff, donors visiting the blood bank, and older people in a senior residence. All subjects were apparently healthy, ambulatory and self-sufficient, 
and none had clinical or laboratory evidence of coagulation, liver, kidney or other disorders.

\section{Blood sampling and processing}

Venous blood was collected in siliconized Vacutainer tubes (Beckton Dickinson, Milan, Italy) containing $0.13 \mathrm{M}$ trisodium citrate, nine parts of blood to one part of trisodium citrate. In two patients, $7500 \mathrm{IU}$ of unfractionated heparin (Liquemin, Roche S.p.A., Milan, Italy) were injected in the same antecubital vein from which the pre-heparin blood sample was taken. Post-heparin samples were taken after 10 minutes from the other arm. Within 1 hour after collection, blood samples were centrifuged at $2000 \mathrm{~g}$ for 15 minutes at room temperature to obtain platelet-poor plasma, frozen in aliquot parts in liquid mitrogen, and stored at $-80^{\circ} \mathrm{C}$ until analysis. Platelet poor plasma from 40 healthy subjects (age $37 \pm 12$ ), different from those recruited for the control group of this study, was pooled, trozen in aliquot parts in liquid nitrogen, and stored at $-80^{\circ} \mathrm{C}$. This plasma pool was used as reference plasma in all assays pertormed.

\section{Assays}

TFPI activity was measured with a two-stage, end-point amidolytic assay adapted to a microtiter plate. Fifty $\mu l$ of diluted plasma samples $(1 / 10,1 / 20,1 / 40$ for pre-heparin samples, and 1/20,1/40,1/80 for post-heparin samples) were incubated at $37^{\circ} \mathrm{C}$ with $50 \mu \mathrm{l}$ recombinant tissue factor (Ricombiplastin, Ortho Diagnostic Systems, Milan, Italy; final dilution 1/60), $50 \mu$ recombinant activated factor VII (Novo Nordisk, Gentofte, Denmark; $0.19 \mu \mathrm{g} / \mathrm{ml}$ ), and $50 \mu \mathrm{l}$ activated human factor $X$ (Diagnostica Stago, Asnières, France; $0.125 \mu \mathrm{g} / \mathrm{ml}$ ) in $0.05 \mathrm{M}$ glyoxaline. $\mathrm{HCl} \mathrm{pH} \mathrm{7.3,0.1} \mathrm{M} \mathrm{NaCl}, 7.5 \mathrm{mM} \mathrm{CaCl}$. After 30 minutes, residual tissue factor/FVlla was measured by subsampling $25 \mu$ of this mixture in $150 \mu \mathrm{l} 0.035 \mathrm{M}$ Tris- $\mathrm{HCl} \mathrm{pH} \mathrm{7.5,0.11} \mathrm{M} \mathrm{NaCl}, 8.5 \mathrm{mM} \mathrm{CaCl} 2$ containing 0.63 $\mathrm{U} / \mathrm{ml}$ human factor $X$ (Sigma Chemical, St. Louis, MO, USA), $0.5 \mathrm{mM}$ chromogenic substrate $\mathrm{S} 2222$, and $0.025 \mathrm{mM}$ thrombin inhibitor 12581 (both from Chromogenix, Mölndal, Sweden). This second reaction mixture was incubated for 30 minutes at $37^{\circ} \mathrm{C}$, the reaction was stopped with $100 \mu 150 \%$ (vol./vol.) acetic acid, and optical densities were read at $405 \mathrm{nM}$. All samples were assayed with and without factor $X$ in the second stage, and optical densities obtained after the incubation without factor $X$ were subtracted from the values obtained after the incubation with factor $X$, to eliminate influence of carry-over of factor Xa from the first stage, and to minimize possible interference of AT and heparin with the assay. AT activity was measured with a chromogenic assay (Coamate Antithrombin, Chromogenix, Mölndal, Sweden) performed on an ACL-300R automated coagulometer from Instrumentation Laboratories (Ascoli Piceno, Italy). AT antigen was quantified by immunodiffusion (NOR-Par- 
tigen Antithrombin III, Istituto Behring, Scoppito, Italy). PC antigen was measured with a sandwich ELISA using two commercial antibodies (DAKO, Glostrup, Denmark). All assays were performed with a standard curve of reference plasma, and results were expressed in percentage.

\section{Statistical analysis}

Data were analyzed with linear regression analysis and Student's unpaired two-tail $t$-test, using the StatView (BrainPower, Calabasas, CA, USA) software package. Type l error was defined for $\alpha=0.05$ in all tests performed.

\section{Results}

The mean plasma level of TFPI was significantly higher in 31 patients with nephrotic proteinuria than in 62 age- and sex-matched controls (mean $\pm \mathrm{SD}$ : $162 \pm 43$ vs $104 \pm 19 \%$, $p<0.0001$; Fig. 20). No case of TFPI deficiency was found in the group of patients studied. Not all patients had high plasma levels of TFPI, 10 of them had TFPI levels within the normal range (mean $\pm 2 S D$ of controls: $66-142 \%$; Fig. 20). We also measured TFPI levels 10 minutes after intravenous injection of $7500 \mathrm{IU}$ unfractionated heparin (Liquemin) in two male patients. In these two patients, who had plasma (pre-heparin) levels of 231 and $189 \%$, TFPI showed a further 1.66 and 1.87 fold increase (TFPI post / pre) after injection of heparin (Table 3).

Table 3. Levels of TFPI before (plasma) and 10 minutes after intravenous injection of 7500 IU unfractionated heparin (post-hep), and parameters of renal function, AT activity, AT antigen, and $\mathrm{PC}$ in two male patients with nephrotic syndrome (age 42 and 52). TFPI post/pre is the ratio of post-heparin level divided by plasma level.

\begin{tabular}{|c|c|c|c|c|c|c|c|c|c|}
\hline patient & $\begin{array}{l}\text { proteinurke } \\
(9 / 24 h)\end{array}$ & $\begin{array}{l}\text { glbumirir } \\
\text { (a) all) }\end{array}$ & $\begin{array}{l}\text { crealinine } \\
\text { clearance } \\
\text { (imlingulin) }\end{array}$ & $\begin{array}{c}\text { AT } \\
\text { activity } \\
(\%)\end{array}$ & $\begin{array}{c}\text { At } \\
\text { anligen } \\
\% \text {. }\end{array}$ & $\begin{array}{l}\mathrm{PC} \\
(\%) \\
\end{array}$ & $\begin{array}{c}\text { TFPl } \\
\text { plasme } \\
(\%)\end{array}$ & $\begin{array}{c}\text { TFpl } \\
\text { postwep } \\
(\%)\end{array}$ & $\begin{array}{c}\text { TFP } \\
\text { posilphe }\end{array}$ \\
\hline 1 & 23,0 & 2.6 & 34 & 135 & 130 & 218 & 231 & 304 & 1.66 \\
\hline 2 & 220 & 2.6 & 17 & 88 & 90 & 195 & 189 & 353 & 1.87 \\
\hline
\end{tabular}

Also the mean plasma level was significantly increased in the patient group when compared with controls (184 452 vs $98 \pm 18 \%, \mathrm{p}<0.0001$; Fig. 20). Six of the 31 patients had normal PC (62-134\%; Fig. 20). As for TFPI, no PC deficiency was found. AT antigen levels were not significantly different between patients $(104 \pm 19 \%)$ and controls $(101 \pm 12 \%)$, and the mean AT activity level was only slightly increased (108 \pm 19 vs $102 \pm 10 \%)$ with borderline statistical significance ( $p=0.049$ ) (Fig. 20). Three cases of AT deficiency (antigen levels: $66,73,75 \%$; activity: $59,72,81 \%$ ) were found (Table 4 ). In one of these three patients TFPI and PC levels were normal, and in two of them high (Table 4). 


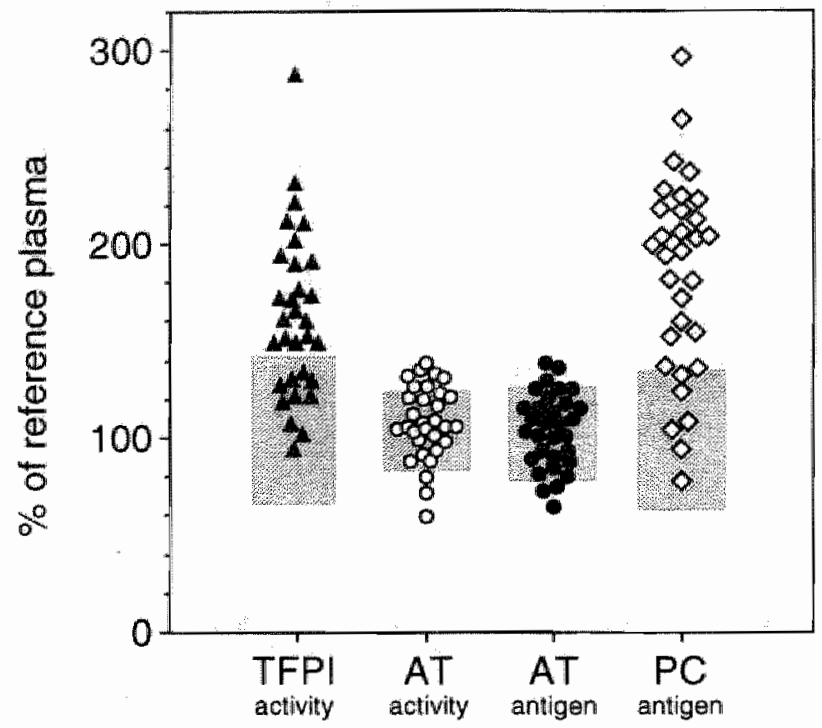

Figure 20. Plasma levels of TFPI activity, AT activity, AT antigen and PC antigen (all expressed in percentage of a pooled reference plasma) in 31 patients with the nephrotic syndrome. The shaded area repre. sents the normal range of each variable, based on the mean plus/minus two standard deviations of the plasma levels in 62 ageand sex-matched controls.

Table 4. Levels of TFPl, PC, proteinuria, abumin, and creatinine clearance in three patients with AT deficiency.

\begin{tabular}{cccccccc}
\hline patient & $\begin{array}{c}\text { proteinutia } \\
(\mathrm{g} / 24 \mathrm{~h})\end{array}$ & $\begin{array}{c}\text { albumin } \\
(\mathrm{g} / \mathrm{d})\end{array}$ & $\begin{array}{c}\text { creatinine } \\
\text { clearance } \\
(\mathrm{m} / \mathrm{min})\end{array}$ & $\begin{array}{c}\text { AT } \\
\text { activity } \\
(\%)\end{array}$ & $\begin{array}{c}\text { ATtigen } \\
(\%)\end{array}$ & $\begin{array}{c}\text { PC } \\
(\%)\end{array}$ & $\begin{array}{c}\text { TFPl } \\
\text { plasma } \\
(\%)\end{array}$ \\
\hline 1 & 6.9 & 2.6 & 103 & 59 & 66 & 237 & 173 \\
2 & 5.8 & 2.3 & 68 & 72 & 75 & 95 & 107 \\
3 & 21.0 & 2.0 & 80 & 81 & 73 & 219 & 172 \\
\hline
\end{tabular}

Linear regression analysis showed that none of the inhibitors (TFPI, PC or AT) were directly correlated with the level of proteinuria, albumin, cholesterol or triglycerides (data not shown).

\section{Discussion}

High plasma levels of TFPI were found in 31 patients with nephrotic proteinuria, and no deficiency of this inhibitor was detected. At least $80-95 \%$ of the TFPI present in plasma is bound to lipoproteins in physiological conditions. ${ }^{23-25}$ These macromolecular complexes might prevent TFPI from passing the basal glomerular membrane in patients with nephrotic proteinuria. Furthermore, plasma levels of TFPI are positively correlated with cholesterol and low-density lipoproteins in normal physiologic conditions, ${ }^{25,26}$ and hyperlipidemia, hypercholesterolemia and hypertriglyceridemia are frequently present in patients with 
the nephrotic syndrome. ${ }^{27.29}$ Therefore, the association of TFPI with lipoproteins might explain the high plasma levels of TFPl in these patients. In some of the patients enroled in our study, plasma TFPI levels reached up to $300 \%$. These high levels are normally found after release of the inhibitor by heparin. ${ }^{18,19}$ Therefore, we tested the hypothesis that these high plasma levels might have been due to a shift of TFPI from the (heparin-releasable) vessel wall-bound pool to the circulating pool. In two representative patients with high resting plasma levels of TFPl, heparin induced a remarkable further increase of the anticoagulant protein in the blood. These results indicate that not only the plasma TFPI pool is large, but also the TFPI pool bound to the vessel wall is of ample proportions in nephrotic patients. Hence, according to our findings, the acquired thrombophilic diathesis in patients with the nephrotic syndrome can not be attributed to TFPI deficiency.

In agreement with previous studies, ${ }^{11-13}$ but in contrast with one, ${ }^{10}$ we found high plasma levels of $P C$ in patients with nephrotic proteinuria. Like for TFPI, no case of PC deficiency was found in the patient group. The loss of a protein in the urine of nephrotic patients is not only determined by its molecular size, but also by the charge of the protein. Anionic sites within the glomeruli form an electrostatic barrier to macromolecular filtration, which may be altered but not completely disrupted in glomerular diseases. As a consequence, molecules with a positive charge pass more readily than those with a negative charge. ${ }^{30}$ $\mathrm{PC}$ is more negatively charged than $\mathrm{AT}$, and urinary loss of PC in nephrotic proteinuria has been shown to be around 40 times lower than that of $A T^{13}$ Besides urinary loss, another mechanism may change blood protein concentrations in the nephrotic syndrome. Studies of an experimental nephrotic syndrome in rats have shown that an increase of the hepatic protein synthesis, particularly of vitamin-K dependent zymogens, accompanies the nephrotic syndrome. ${ }^{3 t, 32}$ Therefore, high plasma levels of $\mathrm{PC}$ in nephrotic proteinuria may be caused by both increased hepatic synthesis and poor urinary loss.

Even though the mean AT antigen level was normal in the group of patients with proteinuria, and mean AT activity only marginally increased, there were three cases of AT deficiency, confirmed by both antigen and activity levels. Two of these patients had high levels of both TFPI and PC, but one patient with AT deficiency had normal TFP I and PC levels. If blood coagulation is an equilibrium which is governed by the sum of procoagulant factors and anticoagulant proteins, the latter patient might theoretically be at a higher risk for venous thrombosis. Only a study of a large group of patients with the same laboratory pattern would elucidate the clinical relevance of this hypothesis.

In conclusion, nephrotic proteinuria is associated with a marked increase of TFPI. As expected, also PC levels were increased, whereas only a minority of 
the patients (3/31) had a substantial AT deficiency. These results show that neither TFPI nor PC deficiencies are involved in the pathogenesis of thrombotic events in nephrotic patients.

\section{References}

1 Llach F. Hypercoagulability, renal vein thrombosis, and other thrombotic complications of nephrotic syndrome. Kidney Int 1985; 28: 429-39

2 Rabelink TJ, Zwaginga $\mathrm{JJ}$, Koomans HA, Sixma JJ. Thrombosis and hemostasis in renal disease. Kidney Int 1994; 46: 287-96

3 Kauffman RH, Veltkamp JJ, van Tilburg NH, van Es LA. Acquired antithrombin III deficiency and thrombosis in the nephrotic syndrome. Am J Med 1978; 65: 607-13

4 Boneu B, Bouissou F, Abbal M, Sie P, Caranobe C, Barthe P. Comparison of progressive antithrombin activity and the concentration of three thrombin inhibitors in nephrotic syndrome. Thromb Haemost 1981; 46: 623-5

5 Vaziri ND, Paule P, Toohey J, Hung E, Alikhani S, Drawish R, Pahl M. Acquired deficiency and urinary excretion of antithrombin III in nephrotic syndrome. Arch Int Med 1984; 144: 1802-3

6 Vigano-D'Angelo S, D'Angelo A, Kaufman CE, Scholer C, Esmon CT, Comp PC. Protein $S$ deficiency occurs in the nephrotic syndrome. Ann Int Med 1987; 170: $42-7$

7 Gouault-Heilmann $M$, Gadelha-Parente $T$, Levent $M$, Intrator L, Rostoker G, Lagrue $G$. Total and free protein $S$ in nephrotic syndrome. Thromb Res 1988; $49: 37-42$

8 Rydzewski A, Mysliwiec M, Soszka J. Concentration of three thrombin inhibitors in the nephrotic syndrome in adults. Nephron 1986; 42: 200-3

9 Toulon $\mathrm{P}$, Gandrille $S$, Remy, $\mathrm{P}$, Chadeuf $\mathrm{G}$, Jouvin MH, Aiach $M$. Significance of high levels of heparin cofactor II in the plasma and urine of adult patients with nephrotic syndrome. Nephron 1992;60: 176-80

10 Soff GA, Sica DA, Marlar RA, Evans HJ, Qureshi GD. Protein C levels in nephrotic syndrome: Use of a new enzyme-linked immunosorbent assay for protein $\mathrm{C}$ antigen. Am J Hematol 1986; 22: 43-9

11 Cosio FG, Harker C, Batard MA, Brandt JT, Griffin JH. Plasma concentrations of the natural anticoagulants protein $\mathrm{C}$ and protein $S$ in patients with proteinuria. J Lab Clin Med 1985; 106: 218-22

12 Pabinger-Fashing I, Lechner $K$, Niessner $H$, Schmidt $P$, Balzar E, Mannhalter $\mathrm{CH}$. High levels of plasma protein $\mathrm{C}$ in nephrotic syndrome. Thromb Haemost 1985; 53: 5-7 
13 Mannucci PM, Valsecchi C, Bottasso B, D'Angelo A, Casati S, Ponticelli C. High plasma levels of protein $C$ activity and antigen in the nephrotic syndrome. Thromb Haemost 1986; 55: 31-3

14 Broze GJ, Warren LA, Novotny WF, Higuchi DA, Girard Jل, Miletich JP. The lipoprotein-associated coagulation inhibitor that inhibits the factor VII-tissue factor complex also inhibits factor Xa: insight into its possible mechanism of action. Blood 1988; 71: 335-43

15 Warn-Cramer BJ, Rao LVM. Maki SL, Rapaport SI. Modifications of extrinsic pathway inhibitor (EPI) and factor Xa that affect their ability to interact and to inhibit factor VIla/tissue factor: evidence for a two-step model of inhibition. Thromb Haemost 1988; 60: 453-6

16 Lindahl AK, Sandset PM, Abildgaard U. The present status of tissue factor pathway inhibitor. Blood Coag Fibrinol 1992; 3: 439-49

17 Salvesen G, Pizzo SV. Proteinase Inhibitors: $\alpha$-Macroglobulins, Serpins and Kunins. In: Hemostasis and Thrombosis: Basic Principles and Clinical Practice. Colman RW, Hirsch J, Marder VJ, Salzman EW, eds. J. B. Lippincott Company, Philadelphia, PA 1994; pp 241-58

18 Sandset PM, Abildgaard U, Larsen ML. Heparin induces release of extrinsic coagulation pathway inhibitor (EPI). Thromb Res 1988; 50: 803-13

19 Ariëns RAS, Faioni EM, Mannucci PM. Repeated released of the tissue factor pathway inhibitor. Thromb Haemost 1994; $72: 327-8$

20 Bombeli T, Mueller M, Haeberli A. Anticoagulant properties of the vascular endothelium. Thromb Haemost 1997; 77: 408-23

21 Sandset PM, Warn-Cramer BJ, Rao LVM, Maki SL and Rapaport SI. Depletion of extrinsic pathway inhibitor (EPI) sensitizes rabbits to disseminated intravascular coagulation induced with tissue factor: Evidence supporting a physiological role for EPI as a natural anticoagulant. Proc Nat Acad Sci USA 1991; 88: 708-12

22 Sandset PM, Warn-Cramer BJ, Maki SL and Rapaport SI. Immunodepletion of extrinsic pathway inhibitor sensitizes rabbits to endotoxin-induced intravascular coagulation and the generalized Shwartzman reaction. Blood 1991; 78: 1496-502

23 Hubbard AR, Jennings CA. Inhibition of the fissue factor-factor VII complex: involvement of factor $X_{a}$ and lipoproteins. Thromb Res 1987; 46: 527-37

24 Novotny WF, Girard JP, Miletich JP, Broze Gd. Purification and characterization of the lipoprotein associated coagulation inhibitor from human plasma. J Biol Chem 1989; 264: 18832-7 
25 Hansen JB, Huseby NE, Sandset PM, Svensson B, Lyngmo V, Nordøy A. Tissue factor pathway inhibitor and lipoproteins: Evidence for association with and regulation by LDL in human plasma. Arterioscler Thromb $1994 ; 14: 223-9$

26 Sandset $\mathrm{PM}$, Larsen ML, Abildgaard $U$, Lindahl AK, Ødegaard OR. Chromogenic substrate assay of extrinsic pathway inhibitor (EPI): Levels in the normal population and relation to cholesterol. Blood Coag Fibrinol $1991 ; 2: 425-33$

27 Marsh JB, Drabkin DL. Experimental reconstruction of metabolic pattern of lipid nephrosis: Key role of hepatic protein synthesis in hyperlipidemia. Metabolism 1960; 9: 946-55

28 Alexander JH, Schapel GJ, Edwards KDG. Increased incidence of coronary heart disease associated with combined elevation of serum triglyceride and cholesterol concentrations in the nephrotic syndrome in man. Med J Aust 1974; 2: 119-22

29 Appel GB, Valeri A, Appel AS, Blum C. The hyperlipidemia of the nephrotic syndrome. Am J Med 1989; 87: 45N-50N

30 Deen WM, Meyers BD, Brenner BM. The glomerular barrier to macromolecules, theoretical and experimental considerations. In: Nephrotic Syndrome. Brenner BM, Stein JH, eds. Churchill Livingstone, New York 1982; pp. $1-29$

31 Girot RF, Jaubert F, Leon M, Bellon B, Aiach M, Josso F, Lepelletier O, Beguin $S$, Monnet JP. Albumin, fibrinogen, prothrombin and antithrombin III variations in blood, urines and liver in rat nephrotic syndrome. Thromb Haemost 1983; 49: 13-7

32 Ibarra-Rubbio ME, Pedraza-Chaverri J, Panduro A. Differential regulation in the expression of hepatic genes in nephrotic and pair-fed rats. Nephron $1993 ; 65: 119-24$ 


\section{Chapter 7}

Tissue factor antigen and activity in human coronary atherosclerotic plaques

Ardissino D, Merlini PA, Ariëns RAS, Coppola R, Bramucci E, Mannucci PM. Lancet 1997; 349: 769-771 


\section{Summary}

Background Coronary atherosclerotic-plaque thrombosis is a key event in the pathogenesis of unstable angina and myocardiall infarction. Although plaque rupture or fissuring frequently occurs in atherosclerosis, only a small proportion of ruptured plaques develop thromboses.

Methods Tissue factor antigen and activity were measured in atherectomy samples from 50 consecutive patients with coronary artery disease (stable angina $n=19$, unstable angina $n=24$, and myocardial infarction $n=7$ ).

Findings Median tissue factor antigen and activity concentrations were significantly higher in plaques from patients with unstable angina and myocardial infarction than in those from patients with stable angina (antigen: $66.1 \mathrm{pg} / \mathrm{mg}$ [interquartile range $43.8-82.5]$ vs $32.4 \mathrm{pg} / \mathrm{mg}[9.8-43.4], p=0.0001$; activity 0.22 $\mathrm{mU} / \mathrm{mg}[0.17-0.41]$ vs $0.13 \mathrm{mU} / \mathrm{mg}[0.05-0.16], p=0.0004)$.

Interpretation Tissue factor, an initiator of the coagulation cascade, may account for the different thrombotic responses to the rupture of human coronary atherasclerotic plaques.

\section{Introduction}

Atherosclerotic plaque rupture or fissuring is a key event in the pathogenesis of unstable angina and myocardial infarction. ${ }^{1,2}$ The exposure of blood to a procoagulant surface triggers thrombin generation, platelet aggregation, and fibrin deposition and leads to thrombus formation that can precipitate an acute coronary event. However, atherosclerotic plaques may rupture without triggering thrombosis. Necropsy data show that between $9 \%$ and $16 \%$ of people who die suddenly of non-cardiac causes have fissured plaques without thrombosis in their coronary arteries, but patients who die of cardiac causes have both thrombosed and non-thrombosed ruptured plaques. ${ }^{\text {jos }}$ The reasons why some ruptured plaques develop thrombosis and others do not are still not known.

Tissue factor, a transmembrane protein that is not in contact with blood, is a major initiator of the blood coagulation process. ${ }^{6}$ Tissue factor has been found in coronary atherosclerotic plaques but whether the tissue factor content varies with different clinical presentations and whether this protein is functionally active is not known.

We measured the amount and activity of tissue factor in atherosclerotic plaques obtained during atherectomy in patients with different clinical manifestations of coronary artery disease. 


\section{Methods}

We studied 50 consecutive patients with coronary artery disease and a focal atherosclerotic lesion in a native coronary artery or bypass graft suitable for atherectomy. All patients gave written informed consent. The patients were prospectively assigned to diagnostic subgroups by their attending physician. Stable angina $(n=19)$ was defined as a history of chest pain, induced by exercise or normal daily activity, for more than 6 months; on exercise testing at least $1 \mathrm{~mm}$ of ST-segment depression on the electrocardiogram was noted. Unstable angina $(n=31)$ was defined as chest pain which occurred at rest accompanied by transient ischaemic electrocardiographic changes, and serum concentrations of creatine kinase MB fraction less than twice the upper limit of normal. Acute myocardial infarction $(n=7)$ was defined as persisting chest pain while at rest with ischaemic electrocardiographic changes which evolved into pathological Q-wave or T-wave inversion and an increase in the MB fraction of creatine kinase of more than twice the upper limit of normal.

Lesion morphology at angiography was prospectively assessed by two angiographers (DA, EB). Complex lesions had irregular borders, overhanging edges, or ulceration and coronary thrombosis was defined as spherical, ovoid, or irregular intraluminal filling defects surrounded on at least three sides by contrast medium just distal to or within a coronary stenosis.

The extracted atherosclerotic plaques were immediately frozen and stored at $-80^{\circ} \mathrm{C}$ until analysis. The assays were done by investigators not aware of the clinical status. After thawing, the lipid-bound proteins in the plaques were solubilised with $1 \%$ Triton $X-100$ in phosphate-buffered saline for $2 h$ at room temperature and then centrifuged at $50000 \mathrm{~g}$ for $1 \mathrm{~h}$ at $20^{\circ} \mathrm{C}$. Control experiments have shown that this procedure extracts all of the tissue factor in the plaques.

Tissue factor antigen was measured in each sample at two dilutions ( $1 / 5$ and 1/10) by ELISA (American Diagnostica Inc., Greenwich CT, USA). Tissue factor activity was analysed by a chromogenic factor $X$ a generation assay. The detergent Triton solubilises transmembrane proteins by disrupting the phospholipid bilayer in which they are inserted and, since tissue factor efficiently catalyses the proteolysis of factor $X$ by activated factor $V I I$ only when inserted in the phospholipid bilayer, detergent extraction abolishes its activity. The addition of procoagulant phospholipids (Thrombofax Cephalin, Ortho Diagnostic Systems S.p.A., Milan, Italy) fully restores tissue factor activity both in detergent extracts of atherectomy specimens and in detergent-treated recombinant-tissue factor (data not shown). Thus, $35 \mu \mathrm{L}$ diluted $(1 / 5,1 / 10$, and $1 / 20)$ detergent-extracted plaque proteins were incubated at $37^{\circ} \mathrm{C}$ with $35 \mu \mathrm{L}$ procoagulant phospholipids prepared from calf brain, $35 \mu \mathrm{L}$ recombinant activated factor VII (Novo Nordisk, Gentofte, Denmark; final 
concentration $200 \mathrm{ng} / \mathrm{mL}$ ), $35 \mu \mathrm{L}$ factor-Xa specific chromogenic substrate S2222 (Chromogenix AB, Mölndal, Sweden; $0.8 \mathrm{mmol} L$ ), and $35 \mathrm{uL}$ purified human factor $X$ (Sigma Chemical Co., St Louis, USA; $0.4 \mathrm{U} / \mathrm{mL}$ ) in $0.03 \mathrm{mmol} / \mathrm{L}$ Tris- $\mathrm{HCl}(\mathrm{pH}$ $7.5), 0.09$ mmol/L sodium chloride, $0.06 \%$ albumin, and $7.2 \mathrm{mmo} / \mathrm{L}$ calcium chloride. The reaction was timed from the addition of factor $X$ and stopped by the addition of acetic acid (25\%) after $30 \mathrm{~min}$. The p-nitroaniline released after the amidolysis of the substrate by activated factor $X$ - which is directly proportional to the tissue factor content of the sample - was measured by colourimetry at $405 \mathrm{~nm}$ against a blank sample containing Triton and phospholipids but without tissue factor. Tissue factor activity is affected by the ratio of Triton to phospholipids, therefore, each assay was done with three standard curves of recombinant tissue factor (Ricombiplastin, Ortho Diagnostic Systems S.p.A., Milan, Italy) diluted from $1 / 80$ to $1 / 20480$ in $0.05 \%, 0.1 \%$, and $0.2 \%$ Triton $X-100$, so that each sample dilution could be referred to a standard curve with a corresponding Triton / phospholipids ratio. $1 \mathrm{U}$ is defined as the amount of tissue factor in $1 \mathrm{~mL}$ Ricombiplastin $(200 \mathrm{ng} / \mathrm{mL})$. When the assay was done in the absence of phospholipids, factor $X$ or both, no colour developed in either the standard curve or the plaque samples: colour developed only in the presence of both reagents. Moreover, the addition of a monoclonal antibody against tissue factor $(5 \mu \mathrm{g} / \mathrm{mL}$ Mab 4508, American Diagnostica Inc., Greenwich CT, USA) quenched $92-100 \%$ of the tissue factor activity in both the standard curves and the plaque samples. The correlation between tissue factor antigen and activity was calculated as Spearman's-rank correlation coefficient. The Mann-Whitney $U$ test was used to test for differences between groups.

\section{Results}

We studied 50 atherosclerotic plaques, of weight $0.1-14.1 \mathrm{mg}$. The total amount of extracted tissue factor antigen ranged from 0 to $3954 \mathrm{pg}$; the ratio of tissue factor antigen to plaque-weight ranged from 0 to $1478 \mathrm{pg} / \mathrm{mg}$ (Fig. 21). The tissue factor activity per $\mathrm{mg}$ plaque weight(Fig. 21) ranged from 0 to $4.67 \mathrm{mU} / \mathrm{mg}$. There was a closecorrelation between the amount of tissue factor antigen and tissue factor activity ( $r=0.87, p<0.0001)$.

Plaques from patients with unstable angina or myocardial infarction had significantly greater concentrations of tissue factor antigen $(p=0.0001)$ and activity $(p=0.0004)$ that those from patients with stable angina (Table 5).

Complex coronary lesions or thrombosis were found in 22 of the 31 patients with unstable angina or myocardial infarction and in one of the 19 patients with stable angina. Complex lesions had significantly higher concentrations of tissue factor antigen $(p=0.0001)$ and activity $(p=0.0019)$ than the uncomplicated lesions (Table 5). 

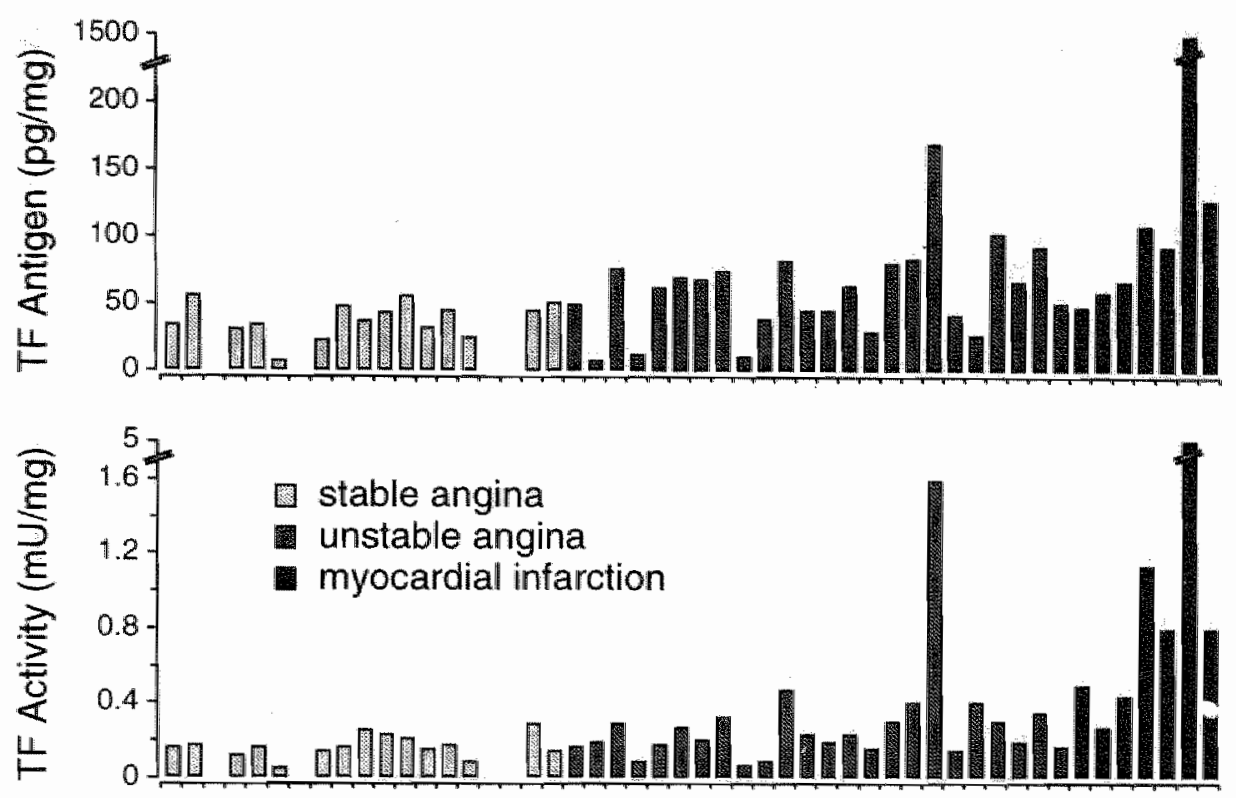

Figure 21. Tissue factor antigen and activity in coronary artherosclerotic plaques.

Table 5. Tissue factor antigen concentrations and activity.

\begin{tabular}{|c|c|c|c|}
\hline & $n$ & $\begin{array}{l}\text { Tissue factor antigen } \\
\text { (pg/mg) }\end{array}$ & $\begin{array}{l}\text { Tissue factor } \\
\text { activity (mU/mg) }\end{array}$ \\
\hline \multicolumn{4}{|l|}{ Clinical status } \\
\hline Stable angina & 19 & $32.4(9.8-43.4)^{*}$ & $0.13(0.005-0.16)^{*}$ \\
\hline $\begin{array}{l}\text { Unstable angina and } \\
\text { myocardial infarction } \\
\text { Lesions }\end{array}$ & 31 & $66.1(43.8-82.5)$ & $0.22((0.17-0.41)$ \\
\hline Uncomplicated & 27 & $32.8(12.5-48.9)^{*}$ & $0.16(0.09-0.21) \$$ \\
\hline Complex & 23 & $73.2(47.5-92.3)$ & $0.27(0.16-0.41)$ \\
\hline
\end{tabular}

Median and interquartile ranges

${ }^{*} p<0.0005$ between clinical status or lesions groups

$\S \mathrm{p}=0.0002$ between lesion groups

\section{Discussion}

We have found that the concentration of tissue factor antigen and activity are higher in atherosclerotic plaques from patients with unstable angina or myocardial infarction than from those with stable angina. Plaques with a complex morphology or coronary thrombosis also have significantly greater amounts of tissue factor antigen and activity. 
Tissue factor, the primary cellular initiator of the coagulation cascade, has a critical role in haemostasis and thrombogenesis. When small quantities of tissue factor come into contact with blood after vessel injury, they form a complex with activated factor VII, which initiates the activation of factor $X$ and factor $X$ and eventually leads to thrombus formation. ${ }^{6}$ Tissue factor is found in blood vessel adventitia, fibrous capsules of organs, epidermis, mucosal epithelium, and stromal cells in the skin and internal mucosae, and thus provides a continuous haemostatic barrier against the external environment ready to activate coagulation when vascular integrity is disrupted. ${ }^{7}$ The expression of tissue factor in blood vessels is strictly regulated to prevent clotting activation under physiological conditions. In pathological conditions, such as atherosclerosis, tissue factor protein has been found in the necrotic cores of atherosclerotic plaques and in the extracellular matrix of arterial walls.,

Fernandez-Ortiz and colleagues ${ }^{10}$ have shown that, in vitro, the atheromatous core of human aortic atherosclerotic plaques is very thrombogenic. A correlation between in vitro platelet deposition on atherosclerotic plaque and the amount of tissue factor measured histochemically suggests that tissue factor protein is a major determinant of the prothrombotic activity of human atherosclerotic lesions. ${ }^{11}$ Marmur and colleagues ${ }^{12}$ found both homogenised and non-homogenised human coronary-atherectomy samples to have different amounts of procoagulant activity associated with tissue factor protein measured by immuno-histochemistry. Our data show that although the amount of tissue factor protein in atherosclerotic plaque is variable, it correlates with tissue factor activity.

The atherosclerotic plaques in this study came from patients with symptoms of ischaemic heart disease; these results may not apply to atherosclerotic plaques in symptom-free individuals. However, coronary artery thrombosis is a key pathogenetic mechanism of unstable angina and myocardial infarction, and these results suggest that the content of tissue factor in the atherosclerotic plaque may determine different thrombotic responses to plaque rupture in human coronary arteries.

\section{References}

1 Fuster $\mathrm{V}$, Badimon $\mathrm{L}$, Badimon $\mathrm{JJ}$, Chesebro $\mathrm{JH}$. The pathogenesis of coronary artery disease and the acute coronary syndromes (1). N Engl J Med 1992; 326: 242-250

2 Fuster $\mathrm{V}$, Badimon $\mathrm{L}$, Badimon $\mathrm{JJ}$, Chesebro $\mathrm{JH}$. The pathogenesis of coronary artery disease and the acute coronary syndromes (2). N Engl J Med 1992; 326: 310-318 
3 Falk E. Unstable angina with fatal outcome: dynamic coronary thrombosis leading to infarction and/or sudden death. Circulation 1985; $71: 699-708$

4 Davies MJ, Thomas AC. Thrombosis and acute coronary-artery lesions in sudden cardiac ischemic death. N Engl J Med 1984; 310: 1137-1140

5 Davies MJ, Bland JM, Hangartner JRW, Angelini A, Thomas AC. Factors influencing the presence or absence of acute coronary artery thrombi in sudden ischemic death. Eur Heart J 1989; 10: 203-208

6 Nemerson $Y$. Tissue factor and hemostasis. Blood 1988; 71: 1-8

7 Drake TA, Morrisey $\mathrm{JH}_{\mathrm{B}}$ Edgington T. Selective cellular expression of tissue factor in human tissues. Am J Pathol 1989; 134: 1087-1097

8 Wilcox JN, Smith KM, Schwartz SM, Gordon D. Localization of tissue factor in the normal vessel wall and in the atherosclerotic plaque. Proc Natl Acad Sci USA 1989; 86: $2839-2843$

9 Annex $\mathrm{BH}$, Denning SM, Channon KM, et al. Differential expression of tissue factor protein in directional atherectomy specimens from patients with stable and unstable coronary syndromes. Circulation 1995; 91 : 619-622

10 Fernadez-Ortiz A, Badimon JJ, Falk E, et al. Characterization of the relative thrombogenicity of atherosclerotic plaque components: implications for consequences of plaque rupture. J Am Coll Cardiol 1994; 23: 1562-1569

11 Toschi V, Fallon JT, Gallo R, et al. Tissue factor predicts the thrombogenicity of human atherosclerotic plaque component. Circulation 1995; 92 : 112 (abstr.)

12 Marmur JD, Thiruvikraman SV, Fyfe BS, et al. Identification of active tissue factor in human coronary atheroma. Circulation 1996; 94: 1226-123 


\section{Chapter 8}

\section{Ticlopidine Pretreatment Reduces Plasma Tissue Factor}

Levels During Coronary Interventions

Ariëns RAS, Gregorini L, Bottasso B, Bamonti-Catena F, Brambilla G, Fajadet J, Bossi I, Cassagneau B, Marco J. 1st Endovascular Therapy Course: Coronary and Peripheral (21-24 May 1997); Marco J, Henry M, Eds 


\section{Abstract}

Coronary dilation procedures are associated with a high risk of thrombosis due to vessel injury and endothelial abrasion, which expose the highly thrombogenic tissue factor (TF) of the subendothelial atherosclerotic matrix to the blood. TF binds and activates coagulation factor VII, leading to thrombin generation and subsequent platelet activation. Plasma TF levels may be an index of TF expression within the vasculature. To investigate if dilation procedures and/or the anticoagulant regimens used during angioplasty affect plasma levels of TF, we measured TF antigen in blood samples collected before dilation in a peripheral vein and the coronary ostium, and soon after the procedures in the coronary ostium and just beyond the dilated lesion in the coronary artery. Measurements were repeated $10 \mathrm{~min}$ after the procedures. Ninety patients were studied: 30 patients with stable angina undergoing conventional angioplasty (PTCA) and 60 patients with unstable angina selected for new percutaneous debulking techniques such as rotational ablation (Rota $n=20$ ) or stent implantation (Stent $n=40$ ). All patients were pretreated with $250 \mathrm{mg} \mathrm{ASA}$, and received $150 \mathrm{U} / \mathrm{kg}$ heparin immediately before collecting samples 1 and 2 . Patients with unstable angina undergoing Rota and Stent received in addition $250 \mathrm{mg} /$ bid ticlopidine $(\mathrm{T})$, half of these patients began $T$ treatment 72 hours and the other half 24 hours before the procedure. Half of the patients undergoing PTCA did not receive T, the other half received $72 \mathrm{~h} T$. None of the dilation procedures (PTCA, Rota and Stent) induced a local increase of plasma TF.

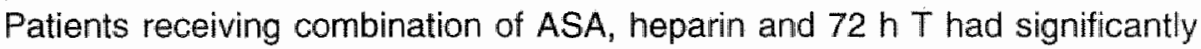
lower TF plasma levels when compared with those receiving no $T$ or $24 \mathrm{~h} \mathrm{~T}$. Plasma TF levels were higher in patients with unstable angina selected for Rota and Stent than in patients with stable angina undergoing PTCA. In conclusion, our study indicates that plasma TF levels are higher in patients with unstable angina than in patients with stable angina, and that anticoagulant regimens with ticlopidine reduce TF levels.

\section{Introduction}

\section{Coronary angioplasty}

Percutaneous transluminal coronary angioplasty (PTCA) is an alternative procedure to surgical revascularization in the presence of atherosclerotic coronary artery disease. ${ }^{1,2}$ Rotational atherectomy ${ }^{3}$ and stent implantation ${ }^{4,5}$ further expand PTCA indications to calcified inelastic plaques and to complicated irregular lesions. PTCA produces endothelial desquamation, splitting of the atheromatous plaque, dissections and fibrous tissue rupture. ${ }^{6}$ The abrasion 
of the endothelium and the rupture of the plaque expose the lipid core and smooth muscles to the blood, activating the hemostatic system. ${ }^{2,7 \cdot 10}$ The generation of thrombin and intracoronary deposition of activated platelets may be responsible for acute and subacute thromboses, which limit the immediate and short term success of PTCA. ${ }^{1-2,7-9,11}$ In addition, serotonin, locally released from the dense granules of the circulating activated platelets, is thought to contribute to post-PTCA coronary vasoconstriction. ${ }^{12}$ Clinical studies with intracoronary injected serotonin suggest that serotonin affects the coronary artery tone ${ }_{3}^{13.14}$ its vasoconstrictor or vasodilator effect being dependent on the presence of a normal endothelium. ${ }^{9.10,13.14}$ We have previously reported that alpha adrenergic receptor antagonists are able to counteract post-PTCA coronary vasoconstriction. ${ }^{15}$

Patients undergoing angioplasty are usually treated with heparin and acetylsalicylic acid (ASA).$^{1-3}$ ASA inhibits the prostaglandin $\mathrm{G} / \mathrm{H}$ synthase, ultimately reducing the formation of thromboxane $A_{2} .{ }^{16-18}$ Heparin, acting as a cofactor, enhances inhibition of both thrombin and activated factor $X$ by antithrombin and heparin cofactor $1 \mathrm{f}^{19}$ In addition, heparin induces a marked release of the tissue factor pathway inhibitor (TFPI, previously known as lipoprotein associated inhibitor or extrinsic pathway inhibitor), ${ }^{20-22}$ which inhibits activated factor $X$ and the TF-factor VII complex. This release of TFPI contributes significantly to the anticoagulant effect of heparin. ${ }^{23}$ Despite this antithrombotic regimen, acute and subacute thromboses still remain a problem in the outcome of PTCA. ${ }^{4,5,8,9}$ With the advent of new devices, such as stents which fracture and rotablator which completely obliterates endothelium, plaque and smooth muscle cells or sometimes the adventitia, effective and safe antithrombotic strategies are needed to avoid acute occlusion, without causing bleeding complications. ${ }^{3-5,24}$ We have recently shown that a combined regimen of ASA, heparin and 72 hours ticlopidine efficiently reduced both thrombin generation and platelet activation complications in patients undergoing rotational ablation and stent implantation. ${ }^{25}$

\section{Tissue factor and coronary thrombosis}

The coagulation cascade is triggered when blood comes into contact with tissue factor (TF), a transmembrane glycoprotein of $53 \mathrm{kD}$. ${ }^{26}$ TF binds coagulation factor VII with high affinity, ${ }^{27}$ and formation of this complex leads to activation of factor VII. TF-activated factor VII subsequently activate factors $X$ and $X$, leading to thrombin generation. ${ }^{26} \mathrm{TF}$ is normally only expressed by perivascular cells, and vital organs like the brain, lung and placenta are very rich in this protein. ${ }^{26}$ Abundance of TF in these organs serves to prevent life-threatening bleeding. TF is distributed as a hemostatic "envelope" ready to activate 
9 lodine/200 mil) was used as a non ionic contrast medium. PTCA was performed by a standard technique using monorail balloon catheter system. Heparin $(150 \mathrm{U} / \mathrm{Kg})$ was iv administered at the beginning of the procedure, according to the weight of patients to keep the clotting time $\geq 300$ sec. During the dilation procedures $1 \mathrm{mg}$ linsidomine (Corvasal, Hoechst $1 \mathrm{mg}$ vials) a nitrous oxide donor and $3 \mathrm{mg}$ isosorbide dinitrate (ISDN) were intracoronary injected. Repeated $3 \mathrm{mg}$ of ISDN were intracoronary supplemented during the rotational atherectomy procedures. Stents (either GT-Roubin or PalmazSchatz stents) were implanted in vessel $\geq 3.0 \mathrm{~mm}$ of diameter and were overexpanded as compared with the nominal diameter of the vessel to obtain a satisfactory result. Immediately after deflating for the last time the balloon, a probing catheter (Cook or Schneider $3 \mathrm{~F}$ ) was quickly inserted on the wire through the monorail side, and positioned in the dilated vessel beyond the stenosis to gently collect blood samples through the 0.018 inch lumen.

\section{Blood Sampling}

Basal blood samples were collected after having administered heparin (150 $\mathrm{U} / \mathrm{Kg}$ ) from a peripheral vein, without tourniquet, using a 19 gauge needle (Bas Vein) and from the guiding catheter (Pre-Procedure) positioned at the coronary ostium through which a guide wire was inserted in the distal coronary artery. Subsequently a precooled plastic syringe was used to gently collected blood samples, which were immediately added to ice chilled plastic tubes containing sodium citrate (9:1 vol.:vol.). After the procedures, blood samples were collected from the dilated coronary artery (Soon after PTCA Dist Artery) with a 0.018 inch probing catheter positioned beyond the lesion and from the proximal coronary artery (Post-PTCA Coronary Ostium) pulting back and washing the probing catheter. Blood samples were collected also 10 minutes after the dilation procedures (10 min Dist Artery, $10 \mathrm{~min}$ Coronary Ostium).

\section{Tissue Factor Assay}

Blood samples were centrifuged at $2000 \mathrm{~g}$ for 15 minutes at $4^{\circ} \mathrm{C}$. The supernatant platelet poor plasma was stored at $-80^{\circ} \mathrm{C}$ until analysis. TF was measured by ELISA using a commercially avallable kit (ImmuBind tissue factor ELISA Kit; American Diagnostica Inc, Greenwich, CT, USA).

\section{Statistical Analysis}

The results are expressed as mean $\pm S E M$. One way analysis of variance for repeated measures using the Fisher correction for multiple comparison for paired data was performed as appropriate (ANOVA). P values of $<0.05$ were considered significant. 


\section{Results}

Plasma TF antigen levels did not increase during PTCA: there were no significant differences between TF levels in samples obtained locally from the proximal coronary artery (Cor Ost) immediately before the procedure and those in samples obtained locally from the proximal coronary artery (Cor Ost) or just beyond the dilated lesion in the coronary artery (Dis Art) soon after or 10 minutes after PTCA (Fig. 22). In addition, samples obtained from a peripheral vein were not significantly different from those obtained from the proximal coronary artery or the dilated coronary artery (Fig. 22). Also in patients undergoing rotational ablation (Fig. 23) or stent implantation, either PalmazSchatz (Fig. 24) or Roubin (Fig. 25) stents, plasma TF antigen levels did not increase during the procedure, and were not different between samples obtained from the various sampling locations.

A marked difference was found between TF levels in patients treated with 72 hours ticlopidine and those treated with 24 hours or no ticlopidine. In patients undergoing PTCA, plasma TF levels were significantly lower in patients receiving 72 hours ticlopidine than in patients receiving no ticlopidine (basal vein, mean \pm SEM: $112 \pm 15$ vs $218 \pm 26 \mathrm{pg} / \mathrm{ml}, \mathrm{p}<0.05$; Fig. 22). In patients selected for rotational ablation, TF levels were even more remarkably reduced in patients receiving 72 hours ticlopidine compared with those receiving 24 hours ticlopidine (basal vein: $193 \pm 13 \mathrm{vs} 446 \pm 47 \mathrm{pg} / \mathrm{ml}, \mathrm{p}<0.05$; Fig. 23). Also in patients

$\mathrm{pg} / \mathrm{mL}$

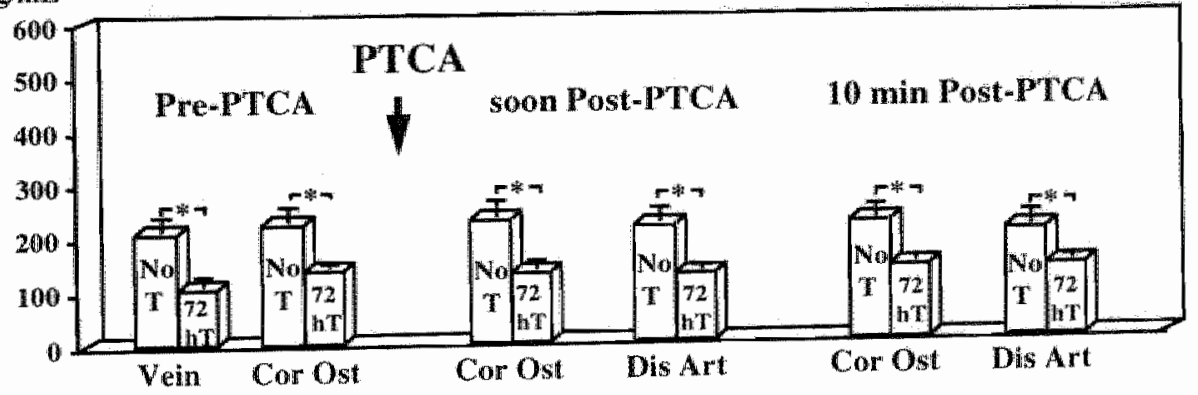

Figure 22. Plasma levels of TF antigen (pg/ml before PTCA (Pre-PTCA), immediately after PTCA (soon Post-PTCA) and 10 minutes after PTCA (10 min Post-PTCA) in 30 patients with stable angina selected for this dilation procedure. Samples were obtained from a peripheral vein (Vein), proximal coronary artery (Cor Ost) and just beyond the dilated lesion in the coronary antery (Dis Art). 15 patients recelved a combined antithrombotic regimen without ticiopidine (Mo T) and 15 patients received a combined antithrombotic regimen with 72 hours ticlopidine $(72 \mathrm{~h} \mathrm{~T})$. Bars depict mean vaIues, error bars show SEM, and asterisks mark statistical significance $(p<0.05)$. 
$\mathrm{pg} / \mathrm{mL}$

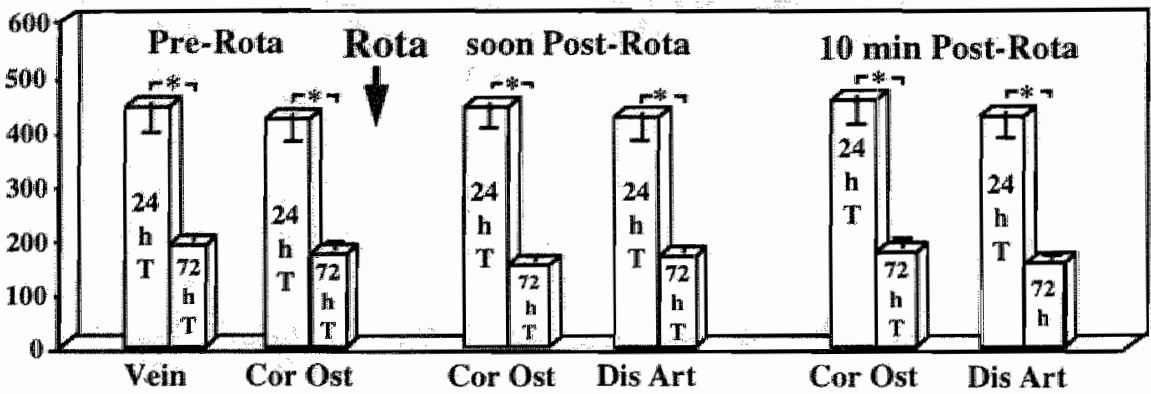

Figure 23. Plasma levels of TF antigen (pg/ml) before rotational ablation Pre-Rota), immediately after rotational ablation (soon Post-Rota) and 10 minutes after rotational ablation (10 min PostRota) in 20 patients with unstable angina selected for this dillation procedure. Samples were obtained from a peripheral vein (Vein), proximal coronary artery (Cor Ost) and just beyond the dilated lesion in the coronary artery (Dis Art). 10 patients received a combined antithrombotic regimen with 24 hours ticlopidine ( $24 \mathrm{~h} T$ ) and 10 patients received a combined antithrombotic regimen with 72 hours ticlopidine ( $72 \mathrm{~h} \mathrm{~T})$. Bars depict mean values, error bars show SEM, and asterisks mark statistical significance $(p<0.05)$.

selected for stent implantation, TF levels were significantly lower in patients treated with 72 hours ticlopidine than in those receiving 24 hours ticlopidine (Palmaz-Schatz stent, basal vein: $179 \pm 15$ vs $447 \pm 64 \mathrm{pg} / \mathrm{ml}, \mathrm{p}<0.05$; Fig. 24;

$\mathrm{pg} / \mathrm{mL}$

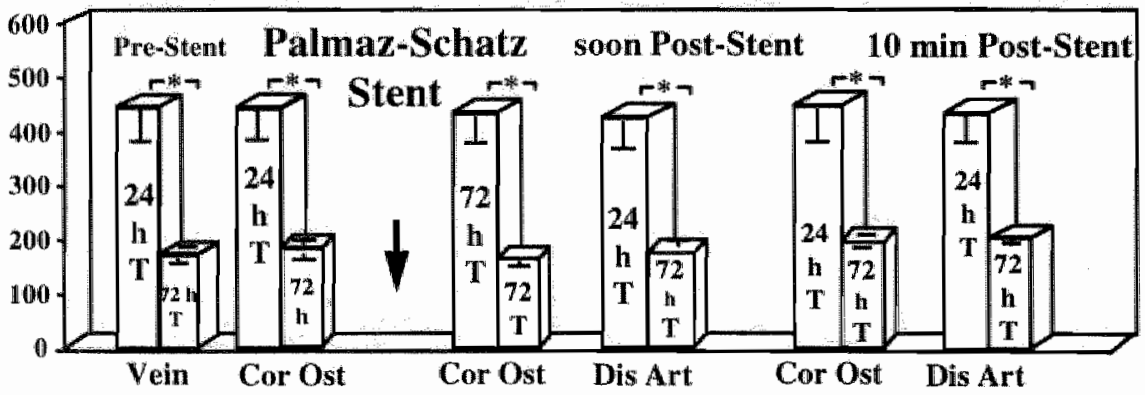

Figure 24. Plasma levels of TF antiglen ( $\mathrm{pg} / \mathrm{m}$ ) before implantation of Palmaz-Schatz stents (Pre-Stent), immediately after stent implantation (soon Post-Stent) and 10 minutes after stent implantation (10 min Post-Stent) in 20 patients with unstable angina selected for this dilation procedure. Samples were obtained from a peripheral vein (Vein), proximal coronary artery (Cor Ost) and just beyond the dilated lesion in the coronary artery (Dis Art). 10 patients received a combined antithrombotic regimen with 24 hours ticlopidine $(24 \mathrm{~h} \mathrm{~T})$ and 10 patients received a combi* ned antithrombotic regimen with 72 hours ticlopidine $(72 \mathrm{~h} \mathrm{~T})$. Bars depict mean values, error bars show SEM, and asterisks mark statistical significance $(p<0.05)$. 
Roubin stent, basal vein: $211 \pm 17$ vs $476 \pm 58 \mathrm{pg} / \mathrm{ml}, p<0.05$; Fig. 25). Samples obtained from the proximal coronary artery and the dilated coronary artery showed the same reduction of TF levels after 72 hours ticlopidine treatment as those obtained from a peripheral vein.

Finally, TF levels in plasma samples obtained from patients with unstable angina selected for rotational ablation and receiving ticlopidine for less than 24 hours were significantly higher than in samples from patients with stable angina undergoing PTCA and not receiving ticlopidine (basal vein: $446 \pm 47$ ws $218 \pm 26$ $\mathrm{pg} / \mathrm{ml}, \mathrm{p}<0.05$ ). Also plasma TF levels of patients with unstable angina selected for stent implantation and receiving ticlopidine for less than 24 hours were significantly higher than those of patients with stable angina undergoing PTCA without ticlopidine treatment (Palmaz-Schatz stent, basal vein: $447 \pm 64$ vs $218 \pm$ $26 \mathrm{pg} / \mathrm{ml}, \mathrm{p}<0.05$; Roubin stent, basal vein: $476 \pm 58 \mathrm{vs} 218 \pm 26 \mathrm{pg} / \mathrm{ml}, \mathrm{p}<0.05$ ).

$\mathrm{pg} / \mathrm{mL}$

$* \mathbf{P}<0.05$

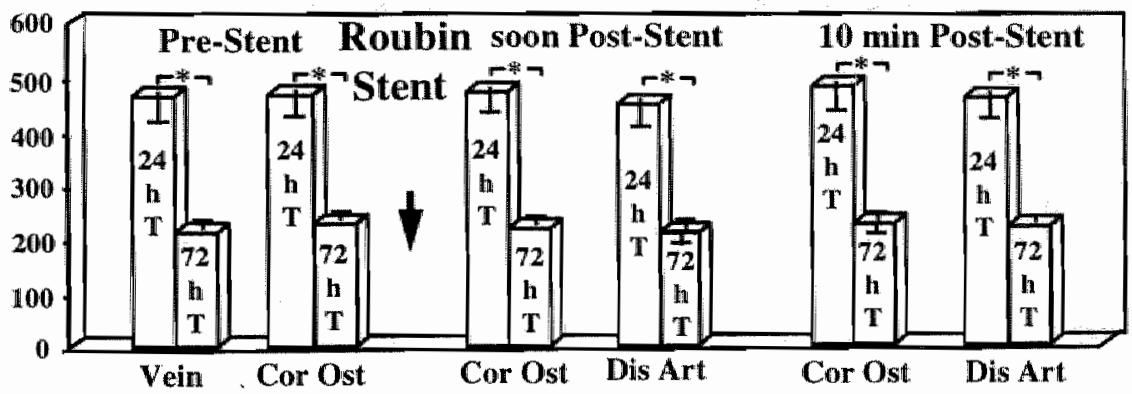

Figure 25. Plasma levels of TF antigen $(\mathrm{pg} / \mathrm{m})$ ) before implantation of GT-Roubin stents (Pre. Stent), immediately after stent implantation (soon Post-Stent) and 10 minutes after stent implantation (10 min Post-Stent) in 20 patients with unstable angina selected for this dilatlon procedure. Samples were obtained from a peripheral wein (Veln), proximal coronary artery (Coir Ost) and just beyond the dilated lesion in the coronaury artery (Dis Art). 10 pattents rocelved a combined antithrombatic regimen with 24 hours ticlopidine $(24 \mathrm{~h} T)$ and 10 patients received a combined antithrombotic regimen with 72 hours ticlopidine $\left(72 h_{i} \mathrm{~T}\right)$. Bars depict mean values error bars show SEM, and asterisks mark statistical significance $(p<0.05)$.

\section{Discussion}

Since dilation procedures such as percutaneous transluminal coronary angioplasty, rotational atherectomy or stent implantation induce abrasion of the endothelium, rupture of the fibrous tissue, dissections and splitting of the atheromatous plaque, ${ }^{6}$ one can hypothesize that TF, which is present in the atherosclerotic lesions with a variable concentration, ${ }^{35,36}$ may be released into circulation during these procedures. However, we did not find significantly increased plasma TF 
antigen levels immediately and 10 minutes after PTCA, rotational ablation, and stent implantation in samples carefully collected locally from either the proximal coronary artery or just beyond the dilated lesion in the coronary artery. Based on these results, we surmize that dilation procedures do not release TF into circulation. However, it may be that we have failed to detect an increase of TF due to inappropriate blood withdrawal or sample timing. It may also be that TF is not found soluble in the plasma after dilation, but associated with micro-fragments of the abrased atheroma, which may be lost during centrifugation of the blood for the preparation of platelet poor plasma, that was used in the TF assays. We are presently investigating if the precipitating fraction of blood withdrawn after dilation procedures contains increased levels of TF. Whether or not dilation procedures release TF into circulation, abrasion of the plaque very likely leads to exposure of functionally active $T F_{3}^{35,36}$ of which, as we showed recently, high concentrations are present in lesions of patients with myocardial infarction and unstable angina ${ }^{36}$

Remarkable low TF plasma levels were found in patients receiving 72 hours ticlopidine treatment, when compared with levels in patients receiving no ticlopidine or those receiving ticlopidine for less than 24 hours. This effect was independent of the type of atherosclerotic lesion (complex or noncomplex) and coronary disease (stable or unstable). These results indicate that ticlopidine treatment for at least 72 hours reduces TF plasma levels. Hence, according to our results, ticlopidine does not only inhibit platelet aggregation, but also significantly lowers plasma TF levels and therefore may inhibit intravascular TF expression and subsequent coagulation activation. In agreement with this finding, we recently showed that, in combination with ASA and heparin, 72 hours ticlopidine treatment efficiently reduced thrombin generation, as measured by prothombin fragment $1+2$ and thrombin-antithrombin complexes. ${ }^{25}$ It is well known that ticlopidine requires approximately 72 hours to be fully active. ${ }^{38.39}$ This is consistent with our findings that ticlopidine when administered for only 24 hours resulted in higher TF plasma levels than when administered for at least 72 hours. The mechanism by which ticlopidine may reduce TF expression is not known. Ticlopidine reduces platelet aggregation by inhibiting ADP-induced platelet activation, ${ }^{40}$ serotonin release from platelets, and expression of the fibrinogen receptor on the platelet membrane. ${ }^{39}$ TF shows structural homology with interferon receptors, and is placed in the cytokine receptor superfamily. ${ }^{41,42}$ Therefore, TF functions as a cellular receptor of factor VII, and since ticlopidine inhibits expression of platelet fibrinogen receptors, it might inhibit expression of TF in a similar fashion.

We found higher mean plasma levels of TF in patients with unstable angina selected for rotational ablation and stent implantation (receiving 24 hours of 
ticlopidine) than in patients with stable angina udergoing PTCA (not receiving ticlopidine). Also after 72 hours of ticlopidine treatment, TF levels tended to be higher in patients with unstable angina than those in patients with stable angina, but the difference was diminished and not anymore statistically significant. These findings are in agreement with previous studies, which showed that monocytes express higher amounts of TF in patients with unstable coronary syndromes, ${ }^{31}$ and that TF antigen and activity were higher in plaque specimens obtained by directional atherectomy from patients with unstable angina and myocardial infarction than in those obtained from patients with stable angina, ${ }^{36}$ and suggest that plasma TF levels may be directly related to TF expression within the vasculature and atherosclerotic lesion. Therefore, plasma TF levels might be an index of the thrombotic risk and acute coronary syndromes during dilation procedures and plaque rupture.

In conclusion, plasma TF levels were higher in patients with unstable angina than in patients with stable angina, and these levels might be an index of the risk of coronary thrombosis induced by TF expression within the vasculature and atherosclerotic plaque. Seventytwo hours of ticlopidine treatment remarkably reduced plasma TF levels, and therefore, besides inhibiting platelet aggregation, this drug might reduce TF dependent coagulation activation.

\section{References}

1 Rayan TJ, Badman WB, Kennedy JW, Kereiakes DJ, King SB III, McCallister BD, Smith SC, Ullyot DJ. Guidelines for percutaneous transluminal coronary angioplasty. A report of the American College of Cardiology/American Heart Association task force on assessment of diagnostic and therapeutic cardiovascular procedures (Committee on percutaneous transluminal coronary angioplasty). J Am Coll Cardiol 1993; 22: 2033-54 Landau C, Lange RA, Hillis DH. Percutaneous transluminal coronary angioplasty. New Engl J Med 1994; 330: 981-93

Warth DC, Leon MB, O'Neill W, Zacca N, Polissar NL, Buchbinder M. Rotational atherectomy multicenter registry: acute results, complications and 6-month angiographic follow-up in 709 patients. I Am Coll Cardiol 1994; 24: $641-8$

Serruys PW, de Jaegere $P$, Kiemeneij F, Macaya $C$, Rutsch $W$, Heyndrickx G, Emanuelsson $H$, Marco J, Legrand V, Materne $P$, Belardi J. Sigwart U, Colombo A, Goy JJ, van den Heuvel P, Delcan J, Morel MA, for the Benestent Study Group. A comparison of balloon-expandablestent implantation with balloon angioplasty in patients with coronary artery disease. N Engl J Med 1994; 331: 489-95 

$K$, Veltri L, Ricci D, Nobuyoshi M, Cleman M, Heuser $A_{s}$ Almond $D$, Teirstein $\mathrm{AS}$, Fish $\mathrm{D}_{1}$ and STRESS investigators. A randomized comparison of coronary-stent placement and balloon angioplasty in the treatment of coronary artery disease. N Engl J Med 1994; 331: 496-501

Waller BF. "Crackers, breakers, stretchers, drillers, scrapers, shavers, burners, welders and melters": the future treatment of the atherosclerotic coronary artery disease? A clinical morphologic assessment. J Am Coll Cardiol 1989; 13: 969-87

7 Fuster V, Steele PM, Chesebro JH. Role of platelets and thrombosis in coronary atherosclerotic disease and sudden death. $J$ Am Coll Cardiol 1985; 5: 175B-184B

8 If $\mathrm{JH}$, Fuster $\mathrm{V}$, Israel D, Badimon L, Badimon J, Chesebro JH. The role of platelets, thrombin and hyperplasia in restenosis after coronary angioplasty. J Am Coll Cardiol 1991; 17: 77B-88B

Gasperetti CM, Gonias SL, Gimple LW, Powers ER. Platelet activation during coronary angioplasty in humans. Circulation 1993; 88: 2728-34

10 Merlini PA, Bauer KA, Oltrona L, Ardissino D, Cattaneo M, Beili C, Mannucci PM. Persistent activation of the coagulation mechanism in unstable angina and myocardial infarction. Circulation 1994; 90: 61-8

11 De Feyter PJ, Van den Brand $M_{\text {s }}$ Jaarman GJ, van Domburg $R$, Serruys $\mathrm{PW}$, Suryapranata $\mathrm{H}$. Acute coronary artery occlusion during and after percutaneous transluminal coronary angioplasty: frequency, prediction, clinical course, management, and follow-up. Circulation 1991; 83: 927-36

12 Golino P, Piscione F, Benedict CR, Anderson HV, Cappelli-Bigazzi M, Indolfi $\mathrm{C}$, Condorelli $\mathrm{M}$, Chiariello $\mathrm{M}$, Willerson $\mathrm{UT}$. Local effect of serotonin released during coronary angioplasty. New Engi J Med 1994; 330: 523-8

13 Mc Fadden E P, Clarke J G, Davies G J, Kaski J C, Haider A W, Maseri A. Effect of intracoronary serotonin on coronary vessels in patients with stable angina and patients with variant angina. N Engl J Med 1991; 324: 648-654

14 Golino P, Piscione F, Willerson J T, Cappelli-Bigazzi M, Focaccio A, Villari $B$, Indolfi $C$, Russolillo $E$, Condorelli $M$, Chiariello M. Divergent effects of serotonin on coronary artery dimensions and blood flow in patients with coronary atherosclerosis and control patients. N Engl J Med 1991; 324: $641-8$

15 Gregorini L, Fajadet J Robert G, Cassagneau B, Bernis M, Marco J. Coronary vasoconstriction after percutaneous transluminal coronary angioplasty is attenuated by antiadrenergic agents. Circulation 1994; 90 : 895-907 
16 Mehta JL, Mehta P, Lopez L, Ostrowski N, Aguila E. Platelet function and biosynthesis of prostacyclin and thromboxane $A_{2}$ in whole blood after aspirin administration in human subjects. J Am Coll Cardiol 1984; 4: 806-11

17 Lembo NJ, Black AJR, Roubin GS, Wilentz JR, Mufson LH, Douglas JS Jr. King SB III. Effect of pretreatment with aspirin versus aspirin plus dipyridamole on frequency and type of acute complications of percutaneous transluminal coronary angioplasty. Am J Cardiol 1990; 65: 422-6

18 Patrono C. Aspirin as an antiplatelet drug. N Engl J Med 1994; 330: 1287-94

19 Barrowcliffe TW, Thomas DP. Antithrombin III and heparin. In: Bloom AL, Thomas DP Eds. Haemostasis and thrombosis. Second edition 1987, Churchill Livingstone, Edinburgh, UK, pp 849-69

20 Sandset PM, Abildgaard U, Larsen ML. Heparin induces release of extrinsic coagulation pathway inhibitor (EPI). Thromb Res 1988; 50: 803-13

21 Lindahl AK, Sandset $P M$, Abildgaard $U$. The present status of tissue factor pathway inhibitor. Blood Coag Fibrinol 1992; 3: 439-49

22 Ariëns RAS, Faioni EM, Mannucci PM. Repeated released of the tissue factor pathway inhibitor. Thromb Haemost 1994; 72: 327-28

23 Lindahl AK, Abildgaard U, Staalesen R. The anticoagulant effect in heparinized blood and plasma resulting from interactions with extrinsic pathway inhibitor. Thromb Res 1991; 64: 155-68

24 McGarry TF Jr, Gottlieb RS, Morganroth J, Zelenkofske SL, Kasparian H, Duca PR, Lester RM, Kreulen TH. The relationship of anticoagulation level and complications after percutaneous transluminal coronary angioplasty. Am Heart J 1992; 123: 1445-51

25 Gregorini L, Marco J, Fajadet J, Bernies M, Cassagneau B, Brunel P, Bossi IM, Mannucci PM. Ticlopidine and aspirin pretreatment reduces coagulation and platelet activation during coronary dilation procedures. JACC 1997; 29: 13-20

26 Nemerson $Y$. Tissue factor and hemostasis. Blood 1988; 71: 1-8

27 Banner DW, D'Arcy A, Chène $C$, Winkler FK, Guha A, Konigsberg WH, Nemerson $Y$, Kirchhofer $D$. The crystal structure of the complex of blood coagulation factor VII with soluble tissue factor. Nature 1996; 380: 41-46

28 Drake DA, Morrissey $\mathrm{JH}$, Edgington TS. Selective cellular expression of tissue factor in human tissues. Am J Pathol 1989; 134: 1087-97

29 Brand $K$, Fowler BJ, Edgington TS, Mackman N. Tissue factor mRNA in THP-1 monocytic cells is regulated at both transcriptional and posttranscriptional levels in response to lipopolysaccharide. Mol Cell Biol 1991;

87: 2254-2258 
30 Donovan-Peluso M, George LD, Hasset AC. Lipopolysaccharide induction of tissue factor expression in THP-1 monocytic cells. J Biol Chem 1994; 269: 1361-1369

31 Neri Serneri GG, Abbate R, Gori AM, Attansio M, Martini F, Giusti B, Dabazzi P, Poggesi L, Modesti PA, Trotta F, Rostagno $C$, Boddi $M$, Gensini GF. Transient intermittent lymphocyte activation is responsible for the instability of angina. Circulation 1992; 86: 790-797

32 Wilcox JN, Smith KM, Schwartz SM, Gordon D. Localization of tissue factor in the normal vessel wall and in the atherosclerotic plaque. Proc Natl Acad Sci USA 1989; 86: 2839-43

33 Fuster V, Fallon JT, Nemerson Y. Coronary thrombosis. Lancet 1996; 348 (suppl): $57-s 10$

34 Moreno PR, Bernardi VH, Lopez-Cuellar J, Palacios IF, Gold HK, Nemerson Y, Fuster V, Fallon JT. Macrophages, smooth muscle cells and tissue factor in unstable angina: Implications for cell mediated thrombogenicity in acute coronary syndromes. J Am Coll Cardiol 1996; 27 (suppl A): 306A

35 Marmur JD, Thiruvikraman SV, Fyfe BS, Arabinda G, Sharma SK, Ambrose JA, Fallon JT, Nemerson Y, Taubman MB. Identification of active tissue factor in human coronary atheroma. Circulation 1996; 94: 1226-32

36 Ardissino D, Merlini PA, Ariëns RAS, Coppola R, Bramucci E, Mannucci PM. Thrombogenic potential of human coronary atherosclerotic plaques. Lancet 1997; 349: 769-71

37 Neuenschwander PF, Morrisey JH. Deletion of the membrane anchoring region of tissue factor abolishes autoactivation of factor VII but not cofactor function. J Biol Chem 1992; 267: 14477-82

38 McTavish D, Faulds D, Goa KL. Ticlopidine an up dated review of its pharmacology and therapeutic use in platelet dependent disorders. Drugs 1990; 40: 238-59

39 Harker LA, Bruno JJ. Ticlopidine's mechanism of action on human platelets. In: Hass WK, Easton JD Eds. Ticlopidine, platelets and vascular disease. Springer Verlag New York. 1991, pp 41-51

40 Cattaneo M, Akkawat $B$, Lecchi A, Cimminiello C, Capitanio AM, Mannucci PM. Ticlopidine selectively inhibits human platelet response to adenosine diphosphate. Tromb Haemost 1991; 66: 694-9

41 Edgington TS, Mackman N, Brand $\mathrm{K}$, Ruf $\mathrm{W}$. The structural biology of expression and function of tissue factor. Throb Haemost 1991; 66: 67-79

42 Bazan JF. Structural design and molecular evolution of a cytokine receptor superfamily. Proc Natl Acad SCI USA 1990; 87: 6934-8 
Chapter 9

General discussion and conclusions 
TFPI, FVIla and FVIIC show a positive correlation with age in the normal, healthy population (chapter 2). This correlation is strongest in women; in men levels of TFPI, FVIla and FVIIc tend to relate with age, but this correlation did not have statistical significance in our study. We surmise that plasma levels of these coagulation proteins are increased by hormonal changes in post-menopausal women. These results show how important it is to carefully select age-and sex-matched control groups in clinical studies of plasma levels of TFPl, FVIla and FVIlc.

Heparin-releasable TFPI is the major vascular pool of this inhibitor, and probably contributes significantly to the anticoagulant properties of the vascular endothelium. In 1994 we showed that 8 intravenous injections of heparin, performed at intervals of 9 to 19 hours, repeatedly released the same quantity of TFPI, as measured by an activity assay (chapter 3 ). Very recently, Hansen et al showed that this release diminished during 5 repeated injections, performed at intervals of 4 hours, and during continuous infusion of heparin. 'This discrepancy is probably due to differences between the assays used and the time intervals of injection. The depletion of heparin-releasable TFPI found by Hansen et al was detected by an antigen assay specific for free TFPI, whereas an activity assay similar to the assay used in our study was less sensitive to the depletion. In addition, Hansen et al performed the heparin injections with shorter time-lag (less than half the time-lag we used). Therefore, we surmise that depletion of heparin-releasable TFPI may occur, but only with intensive heparin therapy (high level and long-term intravenous continuous infusion, and repeated intravenous injections at very short time intervals), whereas during normal, less intensive therapy, there is no risk for TFPI depletion.

Several patients with juvenile thrombosis and low levels of heparin-releasable TFPI, confirmed by both activity and antigen assay, were found (chapter 4). These levels were about half of those in normal controls, which might indicate heterozygous deficiency. For example, AT deficiency is found in heterozygous form only, homozygous deficiency is thought to be incompatible with life. Likewise, TFPI deficiency might exist in heterozygous form only. Seven of the twelve patients with low heparin-releasable TFPI also had low antigen levels of basal (pre-heparin) TFPI. Even though the difference was much less marked than after heparin injection, and basal TFPI antigen did not confirm the results of low post-heparin TFPI in all cases, TFPI antigen assays might detect low total body TFPI without requiring heparin injection. Repeating the TFPI release test after a few months, the defect was shown to be not transient. In addition, the same defect was present in first degree relatives of six patients with low heparin-releasable TFPI, indicating that low heparin-releasable TFPI might be transmitted genetically. These results suggest that heritable defi- 
ciency of heparin-releasable TFPI may be a possible cause of thrombophilia. However, two remarks of reservation have to be made. First, TFPI levels vary more in normal subjects than those of AT, and levels that are half of the mean normal value might therefore not be pathologic. Second, none of the family members studied had experienced episodes of thrombosis, and therefore co-segregation of low heparin-releasable TFPI with thrombosis could not be demonstrated. Further studies, including molecular genetics, are necessary to confirm that deficiency of heparin-releasable TFPI may be a possible cause of thrombophilia.

In chapter 5 we demonstrate the presence of a marked pre-thrombotic state, expressed by high plasma levels of $\mathrm{F} 1+2$ and TAT, in patients with the nephrotic syndrome and proteinuria. We found high levels of FVlla, which shows that the hypercoagulability is due to activation of the tissue factor pathway of coagulation. This increased activation of the tissue factor pathway of coagulation may underlie thromboembolic complications, which are a major threat for these patients. We next investigated if TFPI deficiency would be one of the thrombogenic mechanisms in this syndrome (chapter 6). No TFPI deficiency was found in 31 patients, instead, levels of this natural anticoagulant were remarkably increased. Therefore, the hypercoagulable state and subsequent thromboembolic complications in patients with the nephrotic syndrome are not due to TFPI deficiency.

TF found in human atherosclerotic plaques is functionally fully active (chapter 7). Moreover, we showed that TF antigen and activity is higher in plaque specimens obtained by directional coronary atherectomy from patients with acute coronary syndromes, such as myocardial infarction and unstable angina, than in those obtained from patients with stable angina. Some specimens from patients with stable angina did not contain any measurable amount of TF (chapter 7). Therefore, the thrombotic resonse to plaque rupture, which determines acute coronary syndromes, is dependent on the TF content of the atherosclerotic plaque. Very recently, Marmur et al published a similar study of functionally active TF in directional atherectomy specimens. ${ }^{2}$ However, they did not find a higher TF concentration in specimens from patients with acute coronary syndromes. Besides possible differences in patient selection and atherectomy, this may be due to a different method used for the extraction of TF from the plaque specimens. We used a chemical solvent (Triton $X-100$ ) to extract TF, whereas Marmur et al used short-term (20 seconds), high speed, mechanical homogenization with an electric circular blade homogenizer. Homogenization of an atherosclerotic plaque specimen fragments the tissue, but may lead to incomplete solubilization of its components: Marmur et al found TF activity levels in the plaque specimens of around 5 times less than we did. 
Therefore, they might have failed to detect differences between acute and stable syndromes, because not all TF may have been extracted by the method used.

Plasma levels of TF were significantly higher in patients with unstable angina than in patients with stable angina (chapter 8 ). The comparison of these results with those obtained in chapter 7 suggests that plasma TF levels may be correlated with the level of TF expression in the atherosclerotic plaque. Since in chapter 7 we found that TF expression in the plaque determines the thrombatic response to plaque rupture and acute coronary syndromes, plasma TF levels may result to be useful for determining the risk for thrombosis in atherosclerotic disease. In chapter 8 we also found that ticlopidine significantly reduced plasma TF levels in patients undergoing coronary interventions. Therefore, besides inhibiting platelet aggregation, this drug may exert its antithrombotic action by reducing activation of the tissue factor pathway of coagulation.

\section{References}

1 Hansen ${ }^{B} B$, Sandset PM, Huseby KR, Huseby NE, Nordøy A. Depletion of intravascular pools of tissue factor pathway inhibitor (TFPI) during repeated or continuous intravenous infusion of heparin in man. Thromb Haemost 1996; 76: 703-709

2 Marmur JD, Thiruvikraman SV, Fyfe BS, Arabinda G, Sharma SK, Ambrose JA, Fallon JT, Nemerson Y, Taubman MB. Identification of active tissue factor in human coronary atheroma. Circulation 1996; 94: 1226-32 


\section{Samenvatting}

De bloedstolling is van vitaal belang, zij beschermt het organisme tegen bloeding en waarborgt dat de bloedsomloop gesloten blift. De stolling is een snel reagerend systeem, waarbij stollingsfactoren elkaar activeren in een reeks van biochemische reacties. Belangrijke eigenschappen van dit biochemische systeem zijn positieve feedback en versterking, zodat zelfs een kleine stimulus leidt tot voldoende stolselvorming. Een te hoge activiteit van de bloedstolling kan echter leiden tot inwendige stolsels of trombose. Daarom worden de stollingsfactoren tegengewerkt door specifieke remmers, die vaak via een mechanisme van negatieve feedback de stollingreacties stoppen. De bloedstolling is een fijn uitgebalanceerd proces, dat geactiveerd wordt zodra de vaatwand beschadigd is, maar gecontroleerd wordt in tijd en ruimte wanneer de integriteit van de bloedsomloop hersteld is.

Weefseifactor (tissue facor, TF) activeert de bloedstolling. Dit is een cellulair membraaneiwit dat normaal alleen door perivasculaire cellen tot expressie gebracht wordt. Wanneer het bloed in contact komt met TF-rijke cellen, bindt TF stollingsfactor VII (FVII). De vorming van dit complex leidt tot de activering van factoren IX en X. Geactiveerd factor X (FXa) op zijn beurt activeert factor II of trombine, waarna trombine fibrinogeen in fibrine omzet en bloedplaatjes activeert (figuur 3 , hoofdstuk 1). Het stolsel wordt gevormd door een netwerk van fibrine waaraan zich de geactiveerde plaatjes hechten. De activering van de bloedstolling door weefselfactor wordt specifiek geremd door de tissue factor pathway inhibitor (TFPl) met een negatief feedback mechanisme: TFPI bindt en remt eerst $F X a$, waarna deze remmer een quaternair complex vormt met FXa, FVlla en TF (tiguur 8, hoofdstuk 1).

Het doel van de in dit proefschrift beschreven onderzoek was om de in vivo rol van de tissue factor pathway van de bloedstolling beter te karakteriseren. vooral in relatie tot trombose. Om studies van de componenten van de tissue factor pathway in groepen van patiënten met bepaalde (trombotische) ziekten te kunnen interpreteren, is het van belang goed te begrijpen of en, zo ja, hoe deze componenten variëren in de gezonde populatie. We hebben daarom thet effect van twee belangrijke fysiologische variabelen, leefijd en geslacht, op de bloedplasmaconcentraties van het eerste enzym van de tissue factor pathway (factor VII) en van de remmer TFPI bestudeerd in een grote groep van 160 gezonde mensen, met een leeftijd van 21 tot 101 jaar (hoofdstuk 2). Bloedplasmaconcentraties van TFPI, FVlla (de geactiveerde vorm van factor VII) en FVIIC (het pro-enzym gemeten met een biologische activiteitstest) correleerden allen positief met leeftijd. Het bleek dat deze correlatie het sterkste was in de vrouwelijke helft van de onderzochte groep. Ook bij mannen stijgen de 
bloedplasmaconcentraties van TFPI, FVlla en FVIIc met de leeftijd, maar dit was statistisch niet significant. Het is mogelijk dat de bloedplasmaconcentraties van de componenten van de tissue factor pathway meer met leeftijd correleren bij vrouwen vanwege veranderingen in de hormonenstofwisseling zodra de menopauze inzet. Deze resultaten geven aan hoe belangrijk het is om de juiste, naar leeftijd en geslacht bijpassende, controlegroep te zoeken, wanneer men bloedplasmaconcentraties van TFPI, FVlla en FVllc wil meten in een groep patiënten met een bepaalde ziekte.

Het grootste deel van TFPI bevindt zich niet in het bloed, maar komt vrij na injectie van heparine (een veel gebruikt bloedstalling remmend medicijn). Dit deel is waarschijnlijk gebonden aan heparine-achtige moleculen (glycosaminoglycanen) van de endotheelcellen die bloedvaten omsluiten (figuur 9 , hoofdstuk 1). Om te onderzoeken of deze fractie van TFPI herhaaldelijk vrij gemaakt kan worden, hebben we bij drie vrijwilligers de bloedplasmaconcentraties van TFPI gemeten na herhaalde intraveneuze injecties van heparine (hoofdstuk 3). Het bleek dat 8 achtereenvolgende injecties van heparine (met intervallen van 9 tot 19 uur) telkens dezelfde hoeveelheid TFPI vrijmaakten. Dit is in overeenstemming met de theorie dat deze fractie van TFPI reversibel gebonden is aan de glycosaminoglycanen van het endotheel, en dat heparine deze fractie tijdelijk in de bloedcirculatie brengt. Wanneer de heparine uit de bloedstroom verdwijnt (normaal binnen 2 tot 4 uur na een intraveneuze injectie), bindt de TFPI zich waarschijnlijk opnieuw aan het vasculaire endotheel.

Deficiëntie van de in het organisme voorkomende stollingsremmers kan veneuze trombose en long embolie tot gevolg hebben. Tot nu toe waren er nog geen patiënten met deficiëntie van TFPI en veneuze trombose bekend, maar in voorgaande studies waren alleen bloedplasmaconcentraties van TFPI gemeten. Aangezien de door heparine vrijkomende TFPI waarschijnlijk een belangrijke rol speelt in de stollingsremmende eigenschappen van het vasculaire endotheel, besloten we om te onderzoeken of deficiëntie van deze door heparine vrijkomende fractie kan leiden tot veneuze trombose (hoofdstuk 4). We hebben een aantal jonge patiënten mel veneuze trombose en lage concentraties van de door heparine vrijkomende TFPI gevonden. Deze lage concentraties werden zowel door een biologische activiteitstest als een immunologische test (ELISA) gemeten. Zij bleken ongeveer $50 \%$ van de gemiddelde concentratie in de naar leeftijd en geslacht bijpassende controle groep te ziin. Dit resultaat duidt op een heterozygote deficiëntie. Antitrombine deficiëntie bijvoorbeeld wordt alleen in heterozygote vorm gevonden, homozygote deficiëntie van antitrombine - waarbij er helemaal geen antitrombine in het bloed aanwezig is - is waarschijnlijk niet compatibel met het leven. Analoog zou ook TFPI-deficiëntie alleen in heterozygote vorm kunnen bestaan. Zeven van de 
12 patiënten met lage door heparine vrijkomende TFPI concentraties hadden ook lage basale TFPI concentraties (voor de heparine injectie), wanneer deze gemeten werden met ELISA. In een aantal gevallen kon met behulp van de ELISA-test dus lage concentraties van de door heparine vrijkomende TFPI gemeten worden zonder dat injectie van heparine nodig was, maar de verschillen waren minder duidelijk dan na injectie van heparine. De deficiëntie van de door heparine vrijkomende TFP I bleek geen tijdelijk defect te zijn, want dezelfde lage concentraties werden opnieuw gevonden na een paar maanden. Aangezien lage concentraties van de door heparine vrijkomende TFPI ook werden gevonden bij de naaste familie-leden van 6 patiënten, zijn waarschijnlijk deze lage concentraties genetisch bepaald. Deze resultaten geven aan dat genetische deficiëntie van door heparine vrijkomende TFPI een mogelijke oorzaak is van trombofilie (genetisch overgedragen ziekte van veneuze trombose; zie hoofdstuk 1, paragraaf 1.5). Twee waarnemingen verdienen echter aandacht. Ten eerste bleken de concentraties van TFPI nogal te variëren in de gezonde populatie, meer dan die van bijvoorbeeld antitrombine. Het is dus mogelijk dat TFPI concentraties van $50 \%$ volledig normaal zijn, en niet tot trombose leiden. Ten tweede had geen van de familieleden ooit trombose gehad, en daarom kon er dus geen co-segregatie van trombose met lage concentraties van door heparine vrijkomende TFPI aangetoond worden. Verder onderzoek, naar bijvoorbeeld de moleculaire genetica van het TFPI gen in de patiënten, is nodig om te bevestigen dat deficiëntie van door heparine vrijkomende TFPI werkelijk een mogelijke oorzaak van trombofilie is.

Veneuze trombose komt vaak voor bij patiënten met het nefrotisch syndroom en proteinurie. Men denkt dat verworven deficiëntie van stollingsremmers, door het abnormale verlies van de remmers in de urine, éen van de corzaken van de veneuze trombose is. Inderdaad vonden diverse onderzoekers deficiënties van antitrombine bij patiërten met het nefrotisch syndroom. Het nefrotisch syndroom kan daarom als een in vivo model dienen van veneuze trombose veroorzaakt door deficiënties van stollingsremmers. In hoofdstuk 5 hebben we eerst onderzocht, met behulp van nieuwe testen van stollingsactivering, in hoeverre de bloedstolling geactiveerd is bij patienten met het nefrotisch syndroom. Het bleek dat er een pretrombotische staat aanwezig was bij deze patienten. De pretrombotische staat werd duidelijk door abnormaal hoge bloedplasmaconcentraties van $\mathrm{F} 1+2$ (activeringspeptide van trombine) en TAT (het complex van trombine - antitrombine). Bovendien vonden we abnormaal hoge concentraties van geactiveerd factor VII (FVIla), dat aantoont dat de pretrombotische staat veroorzaakt wordt door activering van de issue factor pathway. Deze verhoogde activering van de tissue factor pathway is waarschijnlijk de oorzaak van de veneuze trombose bij patiënten met het nefrotisch 
syndroom en proteinurie. Vervolgens hebben we onderzocht of deficientie van TFPl een van de mogelijke oorzaken van de verhoogde activering van de tissue factor pathway in deze patiënten zou kunnen zijn (hoofdstuk 6). Geen enkele deficiëntie van TFPI werd gevonden bij 31 patiënten. Integendeel, de bioedplasmaconcentraties van deze remmer waren abnormaal hoog. De concentratie van TFPI was ook hoog na injectie van heparine. Deficiëntie van TFPI kan daarom dus niet de oorzaak zijn van de pretrombotische staat en trombotische complicaties in patiënten met het nefrotisch syndroom.

Atherosclerose van de kransslagaders is de oorzaak van hartaandoeningen. Het breken van de atherosclerotische plaque kan tot trombose en mogelijk tot totale obstructie van de slagader leiden, met acute syndromen zoals hartinfarcten of (onstabiele) angina pectoris als gevolg. Niet alle plaques leiden echter tot trombose wanneer ze breken; tijdens autopsie van personen die niet aan hartkwalen gestorven zijn, worden vaak gebroken plaques zonder trombi in de kransslagaders gevonden. In de literatuur is reeds vaker de hypothese geponeerd dat de hoeveelheid TF, die in de aterosclerotische plaque aanwezig is, bepaalt of het breken van de plaque leidt to trombose. Voldoende bewijs om deze hypothese te bevestigen was echter nog niet gevonden. De onlangs ontwikkelde techniek van directional coronary atherectomy (DCA) heeft het mogelijk gemaakt om met deze relatief weinig invasieve operatie de atherosclerotische plaque uit te snijden en te verkrijgen voor laboratoriumonderzoek. Om te onderzoeken of de hoeveelheid TF die in de plaque aanwezig is bepaalt of trombose plaatsvindt na het breken van de plak, hebben we de TF-concentratie en -activiteit gemeten in plaques verkregen met DCA bij 50 patiënten met hartaanvallen, onstabiele angina pectoris en stabiele angina pectoris (hoofdstuk 7). Ten eerste bleek dat alle TF die aanwezig was in de atherosclerotische plaque ook functioneel volledig actief was. Ten tweede hebben we gevonden dat er meer TF-eiwit en -activiteit aanwezig was in de plaques van patiëriten met hartaanvallen en onstabiele angina pectoris, dan in die van patiënten met stabiele angina pectoris. In sommige plakmonsters van patiënten met stabiele angina pectoris was er geen meetbare hoeveelheid van TF te vinden. We hebben daarom de conclusie getrokken, dat de trombose reactie (die acute infarct-syndromen veroorzaakt) op het breken van de atherosclerotische plaque afhankelijk is van de hoeveelheid TF die in de plaque aanwezig is.

Een aantal verschillende, relatief weinig invasieve technieken, waarbij een sonde wordt ingebracht via een slagader van het been en naar de dichtgeslibde kransslagader wordt geleid, zijn ontwikkeld om de atherosclerotische plaque te verwijderen. Tegenwoordig worden ze vaak toegepast in plaats van de meer invasieve by-pass (die een hartoperatie vereist) om patienten met atheroscle- 
rotische hartaandoeningen te behandelen. Deze technieken, zoals 'percutaneous transluminal coronary angioplasty' of PTCA (waarbij de atherosclerotische plaque wordt ingedrukt door een opblaasbaar ballonnetje), rotatie met een diamanten punt, 'directional coronary atherectomy' of DCA (waarbij een mesje de plaque wegsnijdt en opvangt in een zakvormig uiteinde van de sonde) en het aanbrengen van een stent (een buisvormig netwerkje van metaal dat de ader open houdt), drukken, snijden, breken en schaven de atherosclerotische plaque echter af, zodat de sterk stollingsactiverende kem van de plaque wordt bloot gesteld aan het stromende bloed. Intensieve behandeling met medicijnen die de bloedstolling en de agregatie van bloedplaatjes remmen zijn daarom onmisbaar tijdens deze procedures om acute trombose te voorkomen. In hoofdstuk 8 hebben we het effect van anti-trombose behandeling met de plaatjesagregatie remmer ticlopidine op bloedplasmaconcentraties van TF bestudeerd. Over het algemeen bleek dat bloedplasmaconcentraties van TF hoger waren bij patiënten met acute syndromen (hartinfarct en onstabiele angina pectoris) dan bij patiënten met stabiele angina pectoris. De vergelijking van deze resultaten met die van hoofdstuk 7 doet vermoeden dat bloedplasmaconcentraties van TF correleren met de TF-expressie in de atherosclerotische plak. Omdat de hoeveelheid TF in de plaque de trombose-reactie op het breken van de plaque bepaalt, zou het kunnen zijn dat bloedplasmaconcentraties van TF een indicatie vormen voor het risico van een hartinfarct. Ticlopidine bleek de bloedplasmaconcentraties van TF significant te verlagen bij patiënten die de angioplastische hermodelleringsprocedures ondergingen. Waarschijnlijk remt dit medicijn dus niet alleen de agregatie van bloedplaatjes, maar ook de activering van de tissue factor pathway van de bloedstolling. 


\section{Riassunto}

La coagulazione del sangue è un meccanismo vitale, il quale protegge l'organismo contro il sanguinamento e garantisce l'integrità del sistema vascolare. Essa consiste nell'attivazione di fattori della coagulazione in una serie di reazioni biochimiche veloci. Importanti caratteristiche di tale sistema biochimico sono il feedback positivo e l'amplificazione, cossichè anche uno stimolo piccolo risulta nella formazione di un coagulo sufficiente. Tuttavia, un'attività troppo alta della coagulazione può dar luogo alla formazione di un coagulo intravascolare o trombosi. Per questo motivo esistono degli inibitori specifici, che sono in grado di fermare le reazione della coagulazione, spesso con un meccanismo di feedback negativo. La coagulazione è perciò un processo bilanciato delicatamente, il quale viene attivato appena c'è un danno nel sistema vascolare, ma controllato in tempo e spazio quando è ristabilito l'integrità della circolazione.

La coagulazione è attivato dal fattore tissutale (TF), una proteina transmembranica che normaimente è espresso soltanto da cellule peri-vascolare. Quando il sangue viene in contatto con celiule che esprimono TF, questa proteina lega il fattore VII (FVII), e la formazione di questo complesso porta all'attivazione dei fattori IX e X. Fattore $X$ attivato ( $F X a$ ) a sua volta attiva il fattore $\|$ o la trombina, dopodichè la trombina trasforma il fibrinogeno in fibrina e attiva le piastrine (figura 3 , capitolo 1). Il coagulo è formato da una rete di fibrina a cui si adderiscono le piastrine attivate. L'attivazione della coagulazione da parte del fattore tissutale è inibita dal tissue factor pathway inhibitor (TFPI) con un meccanismo di feedback negativo: TFPI si lega a ed inibisce prima FXa, dopodichè si forma un complesso inibitorio quatemario con FXa, FVIla e TF (figura 8 , capitolo 1).

Lo scopo dei studi discritti in questa tesi è stato quello di analizzare il ruoló della via della coagulazione innescata dal fattore tissutale in vivo, soppratutto in relazione alle patogenesi delle mallatie trombotiche. Per interpretare correttamente se i livelli plasmatici dei componenti di questa via della coagulazione sono correlati a varie patologie, bisogna stabilire se e, se si. come essi variano nella popolazione sana. Per questo motivo abbiamo studiato l'effetto di due variabili fisiologiche (età e sesso) sui livelli plasmatici dell'enzima principale della via del fattore tissutale (fattore Vil) e del suo inibitore (tissue factor pathway inhibitor: TFPl) in un ampio gruppo di 160 individui sani, con l'età tra i 21 e 101 anni (capitolo 2). I livelii plasmatici sia di TFPI, che di FVlla (la forma attivata del fattore VII), che di FVllc (la pro-enzima misurata con un dosaggio di attività biologica) sono correlati positivamente con l'età nella popolazione sana. Questa correlazione è presente soprattutto nelle donne, mentre negli 
uomini TFPI, FVlla e FVllc tendono ad essere correlati con l'età, ma la correlazione non raggiunge una significatività statistica nel nostro studio. Abbiamo ipotizzato che i cambiamenti ormonali in donne in menopausa potrebbero essere la causa del'aumento dei componenti della via del fattore tissutale. Questi risultati dimostrano l'importanza della scelta accurata di gruppi di controllo paragonabili per età e sesso in studi clinici sui livelli plasmatici di TFPI. FVlla e FVIIlc.

II TFPI presente nel plasma costituisce solo una piccola parte della quota totale di questo inibitore nell'organismo. La frazione maggiore di TFPI viene rilasciata dopo iniezione di eparina (un farmaco anticoagulante molto diffuso), - si trova probabilmente legato a molecole simile all'eparina (glicosaminoglicani) presenti sulle cellule endoteliali che circondono i vasil sanguini (figura 9 , capitolo 1). Per studiare se compare tachifilassi nel rilascio di TFPI dopo eparina, abbiamo misurato il TFPI prima e dopo 8 iniezioni endovena di eparina ripetute, da 9 a 19 ore di distanza, in tre soggetti sani (capitolo 3). Ogni dose di eparina rillascia la stessa quantita di TFPI. Questi risultati sono in linea con la teoria che II TFPI che può essere rilasciato dall'eparina sia legato reversibilmente ali glicosaminoglicani presenti sull'endotelio vascolare, e che l'eparina temporaneamente dislochi e trasporti in circolo questa frazione dell'inibitore. Quando l'eparina viene eliminata (di solito in 2-4 ore dopo una iniezione endovena), il TFPI probabilmente si lega nuovamente ai glicosaminoglicani dellendotelio.

Carenze ereditarie di anticoagulanti naturali (antitrombina, proteina $C$, proteina S) causano trombofilia (trombosi venosa su base genetica). Studi effettuati sul coniglio hanno dimostrato che limmuno-deplezione di TFPl causa una massicclia coagulazione intravascolare, ma nessuna carenza di TFPI associato a trombosi è stata finora provata. Tuttavia, negli studi precedenti sul TFPI in pazienti affetti da trombofilia è stato misurato soltanto il TFPI plasmatico, che costituisce una piccola parte del TFPI totale nell'organismo. Poiché il TFPI legato all"endotelio, che può essere rillasciato dall'eparina, è la irazione maggiore dell'inibitore e probabilmente contribuisce significativamente alla proprietà anticoagulante dell'endotelio, abbiamo misurato il TFPI prima e dopo l'iniezione di eparina endovena in un gruppo di pazienti con trombosi giovanile, confrontato con un gruppo di controllo (capitolo 4). In alcuni pazienti affetti da trombosi giovanile, abbiamo messo in evidenza bassi livelli di TFPI dopo il trattamento con eparina, confermati da dosaggi di attività ed antigene. Questi livelli risultano essere la metà rispetto a quelli rilevati in soggetti sani, e potrebbero quindi indicare la presenza di una carenza eterozigote. Ripetendo il test di rilascio dopo qualche mese in questi pazienti, è stato dimostrato che il difetto non è transitorio. Inoltre, abbiamo rilevato gli stessi livelli bassi di TFPI 
dopo iniezione di eparina in almeno un parente di primo grado di sei pazienti. Questi risultati suggeriscono che la carenza di TFPl legato all'endotelio potrebbe essere una causa ereditaria di trombofilia. Tuttavia "due osservazioni meritano l'attenzione. Primo, i livelli di TFPI variano abbastanza nella popolazione sana, di più che per esempio quelli di antitrombina. Esiste quindi la possibilita che livelli bassi siano perfettamente normali, e non risultino in trombosi venosa. Secondo, nessuno dei familiari è andato incontro alla trombosi, e quindi non si è mostrato nessuna co-segregazione dei livelli bassi del TFPI rilasciabile dall'eparina con la trombosi. Ulteriori studi, inciudendo genetica molecolare del gene di TFPI in questi pazienti, sarrano necessari per confermare che la carenza del TFPI rilasciabile dall'eparina possa essere una causa di trombofilia.

Trombosi venosa e tromboembolismo sono una complicanza severa e frequente in pazienti con sindrome nefrosica e proteinuria. Uno dei meccanismi pro-trombotici principali è l'instaurarsi di carenze acquisite di anticoagulanti naturali, causate dalla loro eliminazione nell'urina. La sindrome nefrosica è quindi un modello in vivo di trombosi venosa causata da carenze di anticoagulanti naturali. Innanzitutto, abbiamo esaminato il livello di attivazione della coagulazione innescata dal fattore tissutale in pazienti con sindrome nefrosica, usando nuovi dosaggi di attivazione della coagulazione (capitolo 5). Un aumento della generazione di trombina, espresso da alti livelli plasmatici del frammento della protrombina $1+2(F 1+2)$ e del complesso trombina - antitrombina (TAT), è stato rilevato in questi pazienti. L'aumentata generazione di trombina è causata dall'attivazione della via del fattore tissutale, espresso da alti livelli plasmatici di FVIla. Successivamente abbiamo studiato se l'ipercoagulabilità potesse essere dovuta a carenze acquisite di TFPl, il quale non era stato finora studiato in pazienti con sindrome nefrosica (capitolo 6). Non abbiamo rilevato nessuna carenza di TFPI in 31 pazienti. Al contrario, i livelli di questo anticoagulante naturale sono aumentati notevolmente. Anche I livelli di TFPl dopo iniezione di eparina era alta. Pertanto, l'ipercoagulabilita e le complicanze tromboemboliche in pazienticon sindrome nefrosica non possono essere attribuite a carenze acquisite di TFPI.

Le malattie ischemiche cardiache sono causate dall'aterosclerosi delle arterie coronariche. La rottura della placca aterosclerotica può causare trombosi e l'occlusione totale dell'arteria, con la comparsa di eventi cardiaci acuti, come l'infarto miocardico e l'angina instabile. Tuttavia, non tutte le placche scatenano la trombosi in seguito alla fissurazione; autopsie di soggetti morti per cause non cardiache evidenziano spesso la presenza di placche lese senza trombi. L'ipotesi che il fattore tissutale giochi un ruolo determinante nella risposta trombotica in seguito alla rottura della placca è stata già fórmulata, ma 
gli studi precedenti non forniscono prove conclusive per confermare questa ipotesi. La tecnica recente di aterectomia direzionale (DCA) offre la possibilità di prelevare il tessuto della placca aterosclerotica mediante un intervento relativamente poco invasivo. Per esaminare se il fattore tissutale contenuto nella placca aterosclerotica è funzionalmente attivo e se questo fattore tissutale determina la trombosi in seguito alla rottura della placca, abbiamo misurato l'antigene ed l'attività di fattore tissutale in frammenti di materiale aterosclerotico ottenuti con aterectomia direzionale in 50 pazienti con infarto miocardico, angina instabile e angina stabile (capitolo 7). Uf fattore tissutale presente nelle placche aterosclerotiche umane è funzionalmente attivo. Inoltre, abbiamo dimostrato che il fattore tissutale è significativamente più elevato nelle placche aterosclerotiche di pazienti con eventi cardiaci acuti, come l'infarto miocardico e l'angina instabile, che nelle placche di pazienti con angina stabile. Questi risultati attestano che la risposta trombotica in seguito alla rottura della placca aterosclerotica $\theta$, quindi, gli eventi cardiaci acuti dipendano dal contenuto di fattore tissutale nella placca.

Sono state sviluppate alcune tecniche relativamente poco invasive per rimuovere la placca aterosclerotica nell'arteria coronarica, techniche che attualmente vengono frequentemente usate al posto del più invasivo by-pass coronarico per trattare pazienti con malattie ischemiche cardiache. Tuttavia, queste tecriche (come per esempio Percutaneous Transluminal Coronary Angioplasty o PTCA, rotational ablation con una punta di diamante, DCA e impianto di stent) causano abrasione e rompono la placca aterosclerotica, esponendo il sangue al nucleo di ateroma altamente trombogenico. Per questo motivo, è indispensabile, durante questi interventi, un trattamento intensivo con farmaci che inibiscono la coagulazione e l'aggregazione delle piastrine. In capitolo 8 abbiamo studiato l'effetto del farmaco anti-aggregante ticlopidina sui livelli plasmatici del fattore tissutale. In generale, i livelli plasmatici del fattore tissutale si mostrano più alti nei pazienti con sindromi acuti (infarto miocardico ed angina instabile) che in quelli con angina stabile. II confronto di questi risultati con quelli descritti in capitolo 7 suggersice che i livelli plasmatici del fattore tissutale siano correlati all'espressione del fattore tissutale nella placca aterosclerotica. Siccome abbiamo trovato che il fattore tissutale determina la risposta trombotica alla fissurazione della placca (capitolo 7), i livelli plasmatici del fattore tissutale potrebbero essere un fattore di rischio per l'infarto miocardico. Ticlopidina abbassa i livelli plasmatici del fattore tissutale nei pazienti sottoposti agli interventi cardiaci in modo significativo. Questo farmaco perciò, oltre ad inibire l'aggregazione piastrinica, potrebbe inibire l'attivazione della via della coagulazione del sangue innescata dal fattore tissutale. 


\section{Acknowledgements}

The research described in this thesis was performed in the 'Angelo Bianchi Bonomi' Hemophilia and Thrombosis Centre of the University of Milan, in collaboration with the Department of Biochemistry of the University of Maastricht. Many have contributed to these studies, and I therefore want to shortly list the people who helped me making it all possible.

First I would like to thank my two promotors Prof. Dr. H.C. Hemker and Prof. Dr. P.M. Mannucci, and my co-promotor Dr. S. Béguin, for guiding me through the studies described in this thesis.

I thank my two 'paranimfen' Annemiek Ariëns and Nijs Lagerweij for accepting to assist me in the public discussion of the thesis.

I am indebted to the 'Angelo Bianchi Bonomi' Foundation for their generous fellowships that allowed me to do research in the Hemophilia and Thrombosis Centre.

This thesis concludes a fine period of 6 years in the Hemophilia and Thrombosis Center of Milan. I therefore would like to thank everyone who I met and worked with, and especially: Paolo Cristilli, Rossella Bader, Franco Pareti, Raffaella Coppola, Marco Moia, Ida Martinelli, Giuseppina Alberio, Bianca Bottasso, Daniela Mari, Armando Tripodi, Marco Cattaneo, Nicola di Rocco, Gianluigi Corbani, Lidia Rota Vender, Augusto Federici, Caterina Bressi, Elbio d'Amico e le segretarie Elena e Giuliana.

I would like to thank Dr. D. Ardissino and Dr. P.A. Merlini for the valuable collaborative study, that lead to the interesting results described in chapter 7 .

I also would like to thank Prof. Dr. L. Gregorini for the collaborative study on the effect of ticlopidine on tissue factor (chapter 8).

Thanks also to Tony Ryan, who proof-read the introduction, and helped me with good suggestions and discussions.

I am indebted to Prof. Dr. H.A.M. Neumann, Prof. Dr. C.E. Blanco, Prof. Dr. P.W. de Leeuw, Prof. Dr. P. Prandoni and Prof. Dr. H.J.J. Wellens for being prepared to critically evaluate my thesis.

I would like to thank Trees Camphuisen and Mariet Molenaar in Maastricht who were always prepared to help me with the paper work.

Harke Kazemier, thank you very much for designing the cover of the thesis: and Dirk Kazemier, thanks for processing the design with the computer.

Last but not least I want to thank my parents, who have always supported me, and without whom this thesis would never have been made possible. 


\section{Curriculum vitae}

Robert Ariëns werd geboren op 11 januari 1966 te Heerlen. In 1984 behaalde hil het Gymnasium- $\beta$ diploma aan het lyceum 'Serviam' te Sittard. Van 1984 tot 1990 studeerde hij Biologie aan de Rijksuniversiteit Utrecht, met als hoofdvak Moleculaire Genetica (Dr. J.P.M. Versteeg-Van Oosten en Prof. Dr. P.J. Weisbeek) en als bijvak Moleculaire Celbiologie (Prof. Dr. H.O. Voorma). Het wetenschappelijk onderzoek dat deel uitmaakte van het bijvak Moleculaire Celbiologie heeft hij verricht in the Department of Haematology (Dr. T.W. Barrowcliffe), National Institute of Biological Standards and Control, Potters Bar, Hertfordshire, Groot-Brittanië. In 1990 heeft hij zijn studie aan de Rijksuniversiteit Utrecht met het doctoraal diploma Biologie afgesloten. Van 1991 tot 1997 werkte hij als onderzoeker aan het Centro Emofilia e Trombosi 'Angelo Bianchi Bonomi' (Prof. Dr. P.M. Mannucci), Università di Milano, Italië. Het aldaar verrichtte onderzoek, in samenwerking met Prof. Dr. H.C. Hemker en Dr. S. Béguin, Vakgroep Biochemie, Universiteit Maastricht, heeft tot dit proefschrift geleid. Sinds 1 september 1997 werkt hij als Research Fellow aan de Unit for Molecular Vascular Medicine (Prof. Dr. P.J. Grant), University of Leeds, Groot-Brittanië. 